\title{
Debatten om de nordslesvigske jernbaners udvikling I864-1920
}

\author{
Af $N$. H. Jacobsen
}

Sønderjyske Arbøger 1975 indeholdt en artikel om debatten or de nordslesvigske jernbaners udvikling i tiden før 1864. I denne artikel fortsættes med debatten omkring udviklingen i perioden fra 1864 til genforeningen, hyor udbygningen af det statslige jernbanenet afsluttedes, og landsdelen desuden forsynedes med et vidtforgrenet net af smalsporede småbaner. I et læengere slutningskapitel forsøger forfatteren desuden at give en vurdering af specielt småbanernes erhvervsøkonomiske betydning for Nordslesvig.

\section{Indledning}

Ved fredsslutningen den 30. okt. 1864 indgik der i fredstraktatens artikel XVII den bestemmelse, at den nye regering $i$ hertugdømmerne skulle indtræde i de forpligtelser, som var en følge af kontrakter, der var indgået med den danske regering. ${ }^{1}$ Dette betød bl. a., at det engelske firma, som havde bygget for den danske stat, skulle fuldføre anlægget af de nordslesvigske jernbanestrækninger, som det havde forpligtet sig til at anlægge.

Efter freden i Prag i 1866 blev hertugdømmerne i januar 1867 en preussisk provins. Den nye regering havde naturligvis ikke de samme trafikinteresser som Danmark. Bestræbelserne gik nu ud på at lette hertugdømmernes forbindelse mod syd. Der skal som eksempel på dette nævnes de forandringer, som umiddelbart efter 1867 blev foretaget på den sydslesvigske jernbane.

Banen fra Husum til Rendsborg var blevet ført over Ø. Ørsted og derfra videre til Klosterkro, altså udenom Slesvig by. Fra tysk side er der undertiden - bl. a. i professor Jansens Poleografi (1886) blevet givet meget starke udtryk for utilfredsheden med denne jern- 


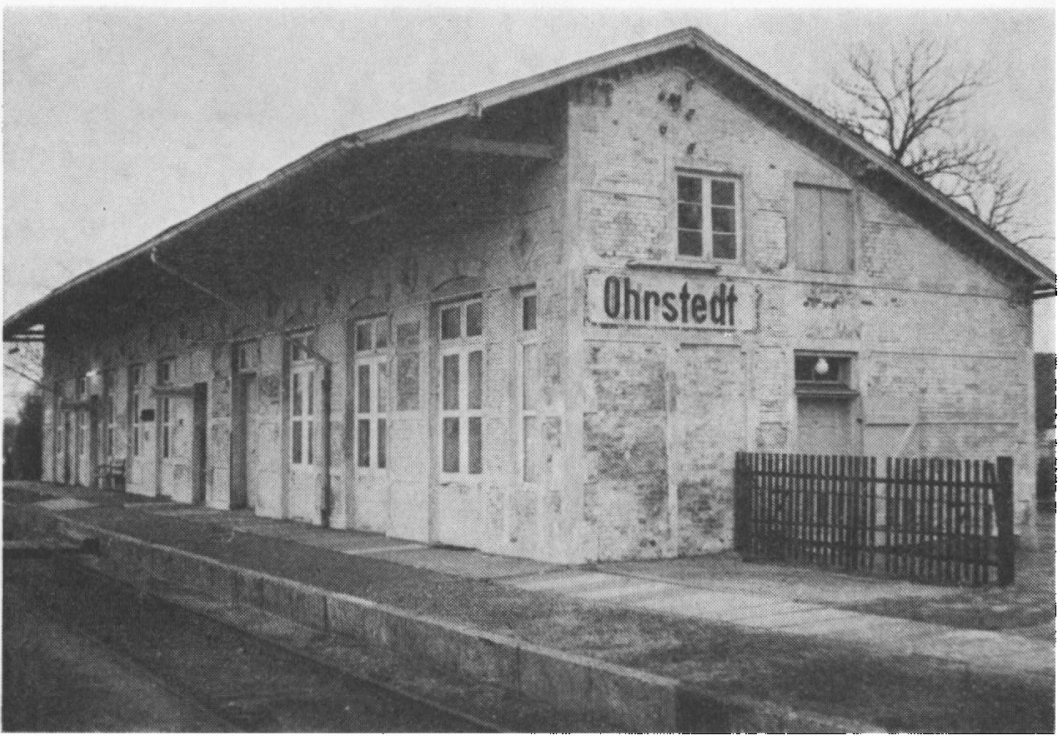

Oster Ørsted banegaird, der blev nedrevet i 1975, var et velbevaret eksempel på stationsbyggeriet $i$ forbindelse med statsbaneanlaggene for 1864.

banes linieføring. Jansen betegner $\varnothing$. Ørsted - Rendsborg banen som et *utroligt forfejlet* udslag af dansk politik ved at »tvinge den nord-sydgående trafik til at tage den utrolige omvej over $\varnothing$. Ørsted og så ovenikøbet lade den fjendtligsindede Slesvig by ligge fjernt fra banen... Denne fejltagelse, som skyldtes et kortsynet partiraseri måtte i 1869 forbedres under nye bekostninger «.

Den forandring, der blev foretaget, bestod i, at der fra Eggebæk på Flensborg-Husum jernbanen blev bygget en jernbane, som over Jybæk og Slesvig blev ført til Klosterkro, hvorfra den så fortsattes ad den allerede bestående bane til Rendsborg. Samtidig med dette blev der foretaget den ændring af banen fra Husum til Flensborg, at den i stedet for, som det indtil da havde været tilfældet, at blive ført over Eggebæk, kom til at udmunde $\mathrm{i}$ den nye bane ved Jybæk. Desuden blev banen fra $\varnothing$. Ørsted til Klosterkro nedlagt. Dette store omlægningsarbejde blev færdig den 1. jan. 1870. Den nye linieføring betød, at jernbanen Flensborg-Slesvig-Rendsborg nu blev hovedbanen, således at der var etableret en langdebane gennem hele halvøen, medens strækningen Jybæk-Husum-Tønning blev sidebane. (Fig. 1). 


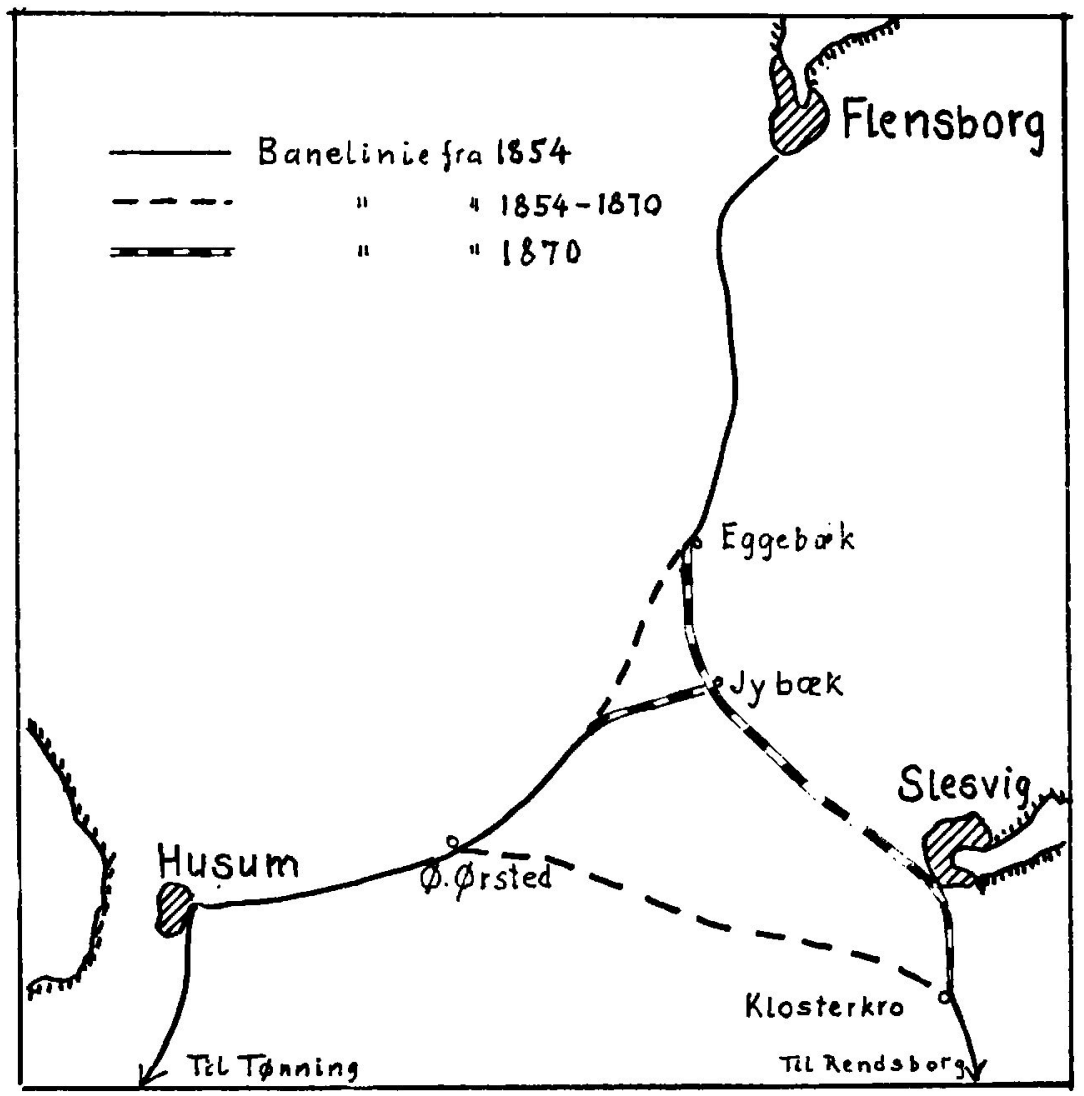

Fig. 1. Omlagningerne af jernbanerne i Sydslesvig 1870.

\section{Vestbanen og vestlesvigske jernbaneplaner}

Den 26. juni 1867 åbnede den $26 \mathrm{~km}$ lange jernbanestrækning mellem Tinglev og Tønder, som var en del af den banestrækning, som Peto's koncession omfattede. Den vestlige endestation for denne bane var den lille banegård *Tønder Øst . Hermed havde Tønder og vestkysten fåt den læenge ønskede jernbaneforbindelse med det østlige Slesvig. Men snart efter kom der planer frem om andre jernbanelinier i disse egne, og blandt de projekter, der dukkede op, var først og fremmest en vestlig længdebane på tale.

Den 1. nov. 1878 åbnedes den af Det holstenske Marskbaneselskab 
anlagte jernbane fra Itzehoe til Heide, og selskabets bestræbelser gik nu ud på at få anlagt en nordlig forlængelse af denne bane. Denne forlængelse skulle over Frederiksstad, Husum og Tønder gå op til den danske grænse. I Tønder var man naturligvis meget interesseret $\mathrm{i}$ en sådan plan, og i 1881 tegnede Tønder byråd for 150.000 mark aktier og Tønder amt for 1 million mark aktier i marskbaneselskabets anlæg af en vestbane. ${ }^{2}$ Efter planen skulle banen fra Tønder gå over Skærbæk til Hviding ved den danske grænse, og den ville altså ikke komme til at berøre Logumkloster. Denne by havde jo gang på gang været et vigtigt punkt $i$ de tidligere forslag om jernbanelinier, og det var derfor ganske naturligt, at der under drøftelserne om vestbanens forløb også blev fremsat tanken om at føre banen over Løgumkloster.

I 1878 havde den tyske civilingeniør E. Dreessen således foreslået bygningen af en bane, der fra Frederiksstad skulle gå over Husum og Tønder til Løgumkloster og derfra til Ribe; men den bane, som han tænkte sig, skulle være en såkaldt sekundærbane. I 1879 fremsattes så tanken om at prøve på at få den påtænkte forlængelse af marskbanen lagt således, at den $\mathrm{i}$ stedet for at gå fra Tonder til Hviding kom til at gå over Løgumkloster og derfra til f. eks. Brørup ved den kongerigske tværbane fra Lunderskov til Esbjerg. Ejendommeligt nok var det ikke fra Legumkloster, men fra »flere beboere i Spandet sogn « at dette forslag blev fremsat. ${ }^{3}$

Man mente, at det nu, da marskbaneselskabet, som ville bygge længdebanen, var begyndt at nivellere linien fra Husum mod nord, var meget vigtigt at få undersøgt, hvilken retning, der nord for Tønder ville blive den mest rentable, og som ville gavne det vestlige Slesvig mest.

Og nu begyndte man også at røre på sig i Løgumkloster. I et indlæg fra H. P. Rosenbom i Løgumkloster i Dannevirke 13. okt. 1879 blev der peget på, at der var foreslået to linier fra Tønder, nemlig den, der gik direkte mod nord langs med chausseen, og så den ovenfor nævnte over Løgumkloster. Men i øvrigt var der desuden i oktober $1879 \mathrm{i}$ Flensburger Norddeutsche Zeitung blevet taget til orde for, at linien fra Tønder til Hviding blev ført over Løgumkloster og Døstrup. Rosenbom foreslog, at der valgtes delegerede, som skulle indkalde til et møde, hvor jernbanesagen så kunne drøftes. Og dette skete meget omgående.

Den 18. oktober kunne Dannevirke meddele, at man på et møde i 
Husum havde fastsat jernbanen fra Heide mod nord således, at strækningen fra Tønder nordpå skulle føres over Visby-Sølsted-Bredebro og Skærbæk til Ribe. Allerede den 20. oktober bragte bl. a. Dannevirke en stor bekendtgørelse, hvori der indkaldtes til et møde den 29. oktober i Gram. Der skulle her arbejdes for, wat den projekterede forbindelsesbane fra Tønder mod nord bliver givet den retning, der må anses heldigst for trafikken $i$ almindelighed og for det nordvestlige Slesvig i særdeleshed «.

På mødet i Gram, hvori deltog 200 mænd fra de forskellige egne, var der stærk stemning for at få bygget en jernbane Tønder-Løgumkloster-Toftlund-Gram-Brørup og med en sidebane fra Gram til Vojens. ${ }^{4}$ Mødets dirigent, Th. Høyer, Agerskov, nævnte, at et bælte med en bredde af 1 mil på hver side af jernbanelinien ville komme til at berøre 23 sogne med over 30.000 indbyggere. Banens længde ville blive ca. $67 \mathrm{~km}$. Ved en lignende beregning ville en ca. $45 \mathrm{~km}$ lang jernbanelinie fra Tønder til Ribe kun komme til at berøre 13 sogne med ialt 9-10.000 indbyggere. Det påtænkte endepunkt, Brørup, havde for det forste den fordel, at det lå ved banen til Esbjerg havn. Endvidere regnede man med, at man i Danmark ville gøre alvor af at anlægge den jernbane fra Herning til Brørup, som tidligere havde været på tale. Man regnede med, at en sådan vestslesvigsk jernbane derigennem ville trække trafikken fra hele det vestlige Slesvig til sig, og at den gennemgående trafik til og fra Nørrejylland også ville få stor betydning for den.

Og det var med en vis berettigelse, at man kunne nære håb om en bane fra Herning til Brorup. I Jylland fulgte man nemlig med stor interesse debatten om den kommende vestslesvigske jernbane, og den 22. okt. 1879 kunne Dannevirke meddele om et andragende, som man fra Nørrejylland ville indsende til indenrigsministeren, og hvori der ville blive ansegt om, at bygningen af jernbanen fra Herning til Skjern måtte blive stillet $\mathrm{i}$ bero, indtil spørgsmålet om en vestslesvigsk jernbanes linieføring var blevet afgjort. Hvis resultatet nemlig blev, at Brørup blev udpeget som endepunkt for den slesvigske vestbane, *ville det være blottet for enhver tvivl, at en bane mellem Herning og Brørup ville bære prisen fremfor en bane fra Herning til Skjern «. Men den komité, som på mødet i Gram var blevet nedsat, for at den skulle forhandle med marskbaneselskabet, opnåede ikke noget resultat. Da selskabet endnu ikke havde fået nogen koncession - det 
skete først den 25 . april 1884 - havde man håbet på, at man kunne forhandle med selskabet om at lagge banen længere mod ost end planlagt. Men marskbaneselskabet stod fast. Det ville ikke vige fra den linie, som det havde fastlagt.

Den 15. nov. 1887 kunne så hele den nordlige forlængelse af den holstenske marskbane, strækningen fra Heide til Hviding, åbnes for driften, og dermed var den såkaldte Marskbane færdig. Den vestbanegård, der i Tønder blev opført til den nye jernbane, blev kaldt Marskbanegården, et navn, som den beholdt til nogle år efter genforeningen, og til denne vestlige banegård blev nu også banen fra Tinglev fort igennem.

Ved den linieføring, som vestbanen havde fået, kom den således til at gå vest for Løgumkloster, og for at bode på dette for denne by så uheldige forhold blev der omtrent samtidig med længdebanen anlagt en ca. $9 \mathrm{~km}$ lang sidebane fra Bredebro til Logumkloster. Denne bane åbnedes for driften den 21. sept. 1888. Både vestbanen og banen til Løgumkloster blev som de sidste af de nordslesvigske banestrækninger overtaget af staten den 1. jan. 1890. De øvrige baner i denne landsdel var allerede fra den 1. jan. $1883 \mathrm{blev}$ drevet for statens regning.

Tønder var altså nu blevet den af de nordslesvigske byer, der havde fået de bedste jernbaneforbindelser. Fra nord og syd samt fra ost førte jernbaner ind til denne by; men hertil meldte sig tidligt ønsket om at få en jernbane til Højer.

En væsentlig årsag til dette ønske var, at der på grund af opblomstringen af badelivet ved Vesterland og de andre badesteder på Sild, var en ret livlig trafik fra Højer til Munkmarsk på Silds østkyst. Allerede i 1870 rettede indbyggere fra alle egne af Sild en indtrængende anmodning til regeringen om, at Højer kanal måtte blive forbedret af hensyn til postdampskibets sejlads mellem Højer og Sild, og i forbindelse hermed udtalte man ønsket om, at "den påtænkte, men allerede indstillede* forlængelse af jernbanen til Højer måtte blive udført. ${ }^{5}$ Det trak dog længe ud med at få dette onske opfyldt. Ganske vist blev der i 1879 i Tønder tegnet aktier til en hestesporvognsforbindelse fra denne by til Højer; ${ }^{6}$ men først mere end 20 år senere, og efter mange besvarligheder, blev jernbanen til Højer til virkelighed. I 1886 havde den preussiske stat forlangt, at de i dette baneanlæg interesserede kommuner skulle give et bidrag på 75.000 mark, 
hvilket man også gik med til. Men i 1889 meddelte regeringen, at den ikke kunne nøjes med dette bidrag. Man måtte forlange, at de interesserede kommuner uden vederlag afgav jord til banen. $\mathrm{Da}$ denne jord imidlertid ville repræsentere en langt sterre vardi end den tidligere bevilgede sum, blev dette forlangende afslået, selv om man var klar over, at baneprojektet derved muligvis var skudt langt ud i fremtiden. ${ }^{7}$

Det blev dog ikke så slemt som frygtet. I $1890 \mathrm{blev}$ der i den preussiske landdag fremsat et lovforslag om anlæg af en jernbanelinie fra Tønder til Højer Sluse, ${ }^{8}$ og den 15 . juni 1892 kunne den $12 \mathrm{~km}$ lange jernbane åbnes for driften. På en vis måde kom banens åbning til at skade Højers erhvervsliv, idet det herefter ikke mere var nødvendigt for de tusinder af badegxster at overnatte i Højer. ${ }^{9}$

En medvirkende årsag til, at lovforslaget om bygning af en jernbane fra Tonder til Højer blev fremsat i den preussiske landdag i 1890 , har sikkert været, at man netop på dette tidspunkt var meget optaget af planen om, at der på Nordslesvigs vestkyst blev skabt en havn med dertil knyttede jernbaneforbindelser, og i denne forbindelse måtte Højer naturligvis komme med $\mathrm{i}$ billedet. Men at man også kunne tænke sig andre havnemuligheder $i$ disse egne fremgår af, at det $\mathrm{i}$ det nævnte lovforslag blev fremhævet, at der kunne være tale om en fortsæettelse af Tønder-Højer-banen til Emmerlev.

Ganske kort tid efter, at Slesvig var blevet afstået til Preussen og $\varnothing$ strig, havde grev A. Baudissin fremsat en plan om bygningen af en havn ved Havneby på Rømø, og fra denne havn skulle forbindelsen med fastlandet etableres ved en dæmning. Denne plan blev modtaget med stor interesse, men krigsudbruddet i $1870 \mathrm{og}$ grev Baudissins død forhindrede dens virkeliggørelse. ${ }^{10}$

I 1887 tog den preussiske regering tanken om et havneanlæg ved Lister Dyb op på ny, men denne gang i udvidet skikkelse, idet der $\mathrm{i}$ forbindelse med et sådant havneanlæg blev foreslået anlæg af jernbane over til en østkysthavn. Man regnede med, at der derved ville være skabt en ny og betydningsfuld gennemgangsrute fra Nordsøen til Østersøen, en rute, »som kunne blive en virksom konkurrent til den danske jernbanelinie fra Esbjerg til Fredericia «. ${ }^{11}$

Regeringen syntes dog ikke at vare meget stemt for Baudissins gamle projekt om en havn på sydspidsen af Rømø, men var mere optaget af tanken om et havneanlæg ved Emmerlev, selv om det på 
grund af den lave vandstand dér ville blive nødvendigt at anlægge denne havn på en kunstig forhøjning ude på vaderanden, lige ved det sejlbare Højer Dyb, og derfra skulle der så føres en 5-6 km lang jernbanedxmning ind til fastlandet.

I tilslutning til en havn ved Emmerlev kunne der tænkes to tværbaneprojekter til østkysthavne. Det ene projekt gik ud på, at der fra Emmerlev førtes en bane til Bredebro, hvorfra den ved en forlængelse af Bredebro-Løgumkloster banen til Rødekro sattes i forbindelse med Ảbenrå. Efter det andet projekt skulle der fra Emmerlev føres en bane til Tønder, og ved en forlængelse af Tønder-Tinglev banen til Sonderborg ville der være skabt en forbindelse med en god østersøhavn.

Men den gamle tanke om anlæg af en havn på sydspidsen af Rømø var dog langt fra blevet opgivet. Den 3. feb. 1889 afholdtes der i Skærbæk et godt besøgt møde om anlæg af en sådan havn. Mødet åbnedes af pastor C. J. Jacobsen, Skærbæk, der var blevet kendt gennem de forskellige fortyskningsforetagender, som han startede, og som nu udførligt skildrede, hvorledes det $\mathrm{i}$ tidens løb var gået med projekterne om en havn på Rømø. Mødet sluttede med, at der valgtes en komité, som skulle arbejde med sagen. Denne komité vedtog en resolution, som blev indsendt til ministeren for offentlige arbejder, Maybach, og som udtalte befolkningens levende ønske om, at der blev anlagt en havn ved Havneby og i forbindelse hermed bygget en dxmning fra lidt nord for Bolilmark på Rømø til Astrup samt en direkte jernbaneforbindelse til kredsbyen Haderslev. I slutningen af februar indløb der fra vedkommende minister svar "på den for nogen tid siden indsendte massepetition «, og dette svar gik ud på, at projektet ville blive undersegt. 12

I 1889 blev der fra Haderslev sendt en deputation til overpresidenten for Slesvig-Holsten for at anbefale anlxgget af en havn pa Rømø og $i$ forbindelse hermed bygningen af en jernbane, som via en dæmning til Astrup skulle føres over Skærbæk, Toftlund, Vojens og Haderslev til Årøsund.

Den redegørelse for planen, som blev overbragt overpræsidenten, ${ }^{13}$ og som er underskrevet af rådmand Andresen og gymnasielærer Macke, Haderslev, der blandt andet blev kendt som en af de store Knivsbjerg-talere, ${ }^{14}$ anfører, hvorledes den preussiske regering $»$ tilsigter anlæg af en til havfiskeriets fordringer svarende og til ind- og 
udførsel hensyntagende havn «, og dette ville efter komiteens opfattelse bedst kunne opnås ved en havn ved Havneby.

Haderslev kreds havde særlig grund til at ønske en tværbane gennem den nordligste del af Nordslesvig og gik derfor på det bestemteste imod Emmerlev-projektet og de til dette knyttede tværbaner. For det første mente man, at en havn ved Emmerlev lå for langt mod syd til, at den med held kunne konkurrere med Esbjerg og til at kunne drage transporten af de landbrugsprodukter, der nu besørgedes over Esbjerg, til sig. Og desuden udtaltes det, at hvis havnen ved Emmerlev skulle blive bygget, ville det være meget sandsynligt, at der ville blive bygget en jernbane til Ảbenrå. Dette ville betyde, at det $\mathrm{i}$ fremtiden ville blive yderst vanskeligt - for ikke at sige umuligt - at opnå at få en tværbane gennem Haderslev kreds, »og den nordlige del af provinsen, der allerede $i$ forvejen befinder sig $i$ en meget betrængt stilling, både $\mathrm{i}$ økonomisk og politisk henseende, ville «, som det hedder i skrivelsen, wherefter undvære et af de virksomste midler til fremme for og forogelse af dens velstand og til udbredelse af tysk nationalt sindelag og kultur«.

Skrivelsen ville dog efter Dannevirke den 20. okt. 1889 ikke vakke udelt sympati i Haderslev kreds og på Rømø, når det blev klart for indbyggerne her, at et af formålene med denne bane var at fremme tyskheden. Der var nemlig, efter hvad Dannevirke skriver, sket dette, at der i 1888 blandt beboerne i Haderslev kreds og på Rømø var blevet indsamlet underskrifter på et andragende til vedkommende preussiske minister, og dette andragende var ledsaget af wen slags dansk oversættelse «, $\mathrm{i}$ hvilken der udelukkende blev henvist til de okonomiske fordele, som det påtænkte anlæg ville bringe Haderslev kreds. Men den danske oversættelse bragte ikke alt, hvad der stod i den tyske tekst. F. eks. var det ovenfor anførte citat om jernbanens forventede betydning for udbredelsen af tysk sindelag og kultur ganske udeladt i den danske oversxttelse. Ligeledes var der udeladt den passus, der hentyder til, at ved denne jernbane "ville byen Haderslev med endnu større succes kunne opfylde sit med hengivenhed røgtede kald at være højborg og midtpunkt for den endnu svage tyskhed $\mathrm{i}$ fædrelandets nordlige del $\ll$.

»Der er, som man ser«, hedder det i Dannevirkes artikel, »betydelig forskel mellem de to steder, og denne forskel fremkommer ved, at der $\mathrm{i}$ betænkningen slås meget stærkt på den nytte, anlægget vil få i tysk- 
hedens tjeneste. Derom tales der ikke med et ord i oversættelsen. Denne kunne alle underskrive; men ikke en eneste dansksindet mand kan underskrive det, der er lagt $i$ betænkningen uden samtidig at underskrive sin egen og sine meningsfællers nationale dødsdom «.

Men det gik med disse projekter om forbindelsesbaner mellem østog vestkysten, som det var gået med så mange andre - de kom ikke længere end på papiret.

\section{Sønderborgs jernbaneforbindelse med langdebanen}

Medens der efterhånden var blevet anlagt længdebaner $i$ det østlige og vestlige Nordslesvig og en tværbane fra Tinglev til Tonder, trak det længe ud, før der kom en jernbaneforbindelse fra Sønderborg til det øvrige jernbanenet, idet det først var i 1901, at jernbanen fra Sønderborg til Tinglev og Padborg kunne åbnes. Og havde der været mange og lange forhandlinger, før den østslesvigske langdebane kunne bygges, så var de forhandlinger, der gik forud for etableringen af Sønderborg-Tinglev/Padborg banen bestemt ikke mindre.

Når Sønderborg kreds så længe var den eneste i provinsen SlesvigHolsten, der var uden jernbane, skyldes det, at der ikke kunne opnås forlig med den preussiske minister og provinsens overpræsident om, hvilken retning forbindelsesbanen skulle have. Den preussiske minister og overpresidenten var mest interesseret i en bane fra Sønderborg til Padborg, medens Sønderborg kreds kæmpede for at få en bane fra Sønderborg til Tinglev. Dette medførte, at der igennem en snes år var et næsten uafbrudt tovtrækkeri mellem Sønderborg kredsdag og regeringen, således som det klart fremgår af det meget interessante skrift, som justitsråd, kredsdagsmedlem W. Grimm, der havde været borgmester i Sønderborg fra 1868 til 1883, skrev omkring 1892. Undertiden var det, som om Sønderborg kreds kunne nære berettigede forhåbninger om, at nu ville den ønskede bane blive bygget; men så stillede ministeren pludseligt nye betingelser, som kuldkastede alle forhåbninger.

De første, meget spinkle planer om bygningen af en jernbane gennem området mellem Åbenrå Fjord og Flensborg Fjord kom så tidligt som i 1844, da der pludseligt opstod en meget stor og udbredt interesse for jernbaneanlæg. Den ovenfor nævnte plan gik ud på, at der 
skulle bygges en jernbane fra Flensborg til Sønderborg, og fra Sønderborg skulle denne bane så fortsættes til Mommark eller til Fynshav, hvorfra der så skulle være dampskibsforbindelse til Fåborg. ${ }^{15}$

Dette meget løse projekt blev dog ikke til noget, og det var først under debatten om den østslesvigske længdebanes linieføring, at Sønderborg kom ind i billedet. På et møde, som den 15. april $1861 \mathrm{blev}$ holdt i Nybøl herredsråd, var man enige om, at det så kraftigt som muligt burde fremhæves overfor ministeriet for Slesvig, hvorledes Sundeved og Als - og naturligvis ikke mindst Sønderborg - var meget interesseret $i$, at den påtænkte længdebane, med sidebanen til Tønder, blev ført så nær østkysten som muligt, både på grund af den allerede meget betydelige kvægudførsel til Tønder og i ikke mindre grad for at gøre muligheden for den bane, der før eller senere måtte komme fra Sønderborg til det påtxnkte hovedbanenet, lettere. ${ }^{16}$

I 1873 ansøgte Sønderborg kredsdag $\gg \mathrm{i}$ tre fortræffeligt underbyggede skrivelser « til ministeren for offentlige arbejder om bygning af en forbindelsesbane til den slesvigske læengdebane. ${ }^{17}$ I sit svar skrev ministeren, at staten havde ladet en linie fra Padborg til Sønderborg nivellere; men det tilføjedes, at det ikke var ministeriets hensigt at bygge denne bane. Ministeriet henviste iøvrigt Sønderborg til at forhandle med Kiel-Altona-Jernbaneselskabet, hvad der da også skete. Disse forhandlinger førte til en fuldstændig enighed om, at kun en jernbane fra Sønderborg til Tinglev havde interesse for Sønderborg by og kreds.

Det næste skridt i sagen blev, at jernbaneingeniør A. P. Petersen i 1873 udarbejdede en "Oplysende Beretning over det projekterede Baneanlæg Tingleff-Sønderborg «.18 I denne på dansk og på tysk skrevne beretning, der er dateret den 11. maj 1873, og som blev indsendt til ministeren for offentlige arbejder, gøres for det første rede for, at hensigten med det påtænkte baneanlæg var at bringe det rige og frugtbare Sundeved, samt Sønderborg og Als i forbindelse med det slesvigske banenet "ved den korteste og mest hensigtsmæssige vej « for * på denne måde at muliggøre en bedre og promptere afsætning af de derværende produkter, end det hidtil har været tilfældet«. Og derefter anføres den retning, som den påtrenkte, $37 \mathrm{~km}$ lange bane skulle følge. Den skulle udgå fra Tinglev, hvorfra sidebanen til Tønder udgår. Fra Tinglev skulle den gå over Kliplev og Søgård samt syd om Felsted og Tombøl, hvorfra den så førtes over godserne Kiding og 


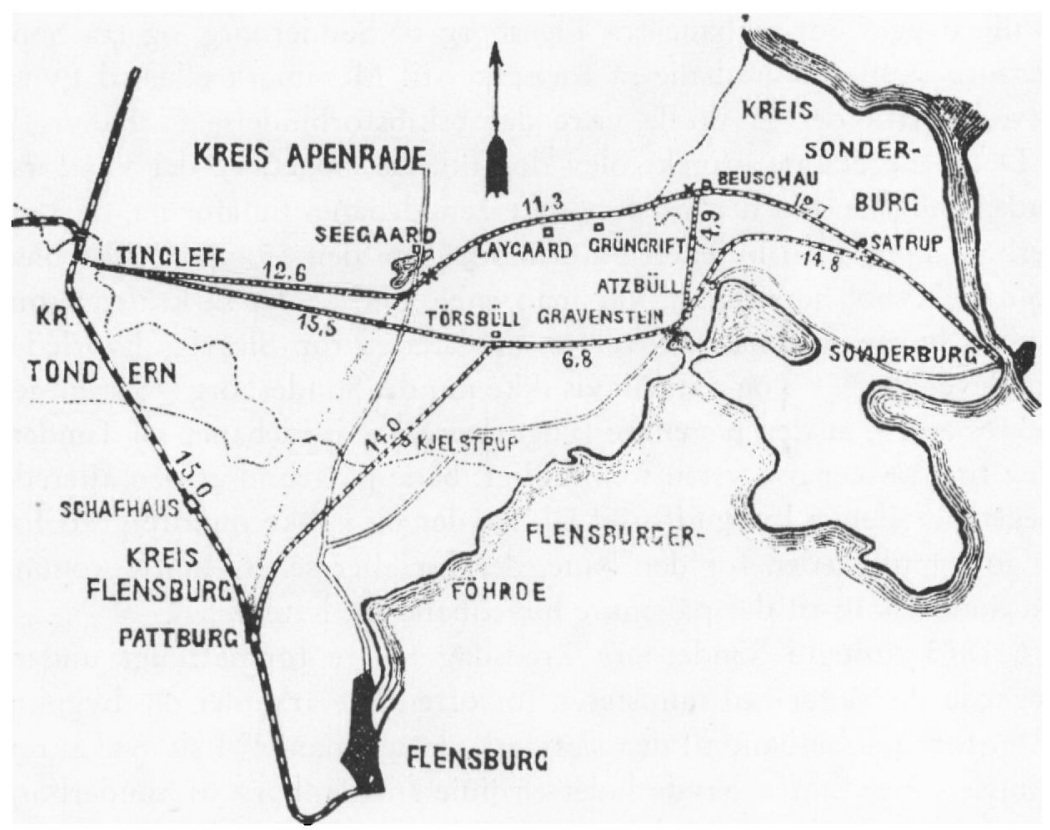

Fig. 2. De forskellige forslag til en jernbane fra Sanderborg til langdebanen, saledes som de foreld 1892 (efter Grimm).

Bojskov og videre mellem landsbyerne Ullerup og Avnbøl til V. Sottrup for tilsidst via Sandbjerg at nå Sønderborg. (Fig. 2).

Ved forhandlingerne med Sønderborg magistrat udtalte Petersen sig naturligvis afgjort for denne sekundærbane til Tinglev og var imod en bane fra Sønderborg til Flensborg. Han anførte, at det for det første var forbundet med meget store vanskeligheder at bygge en sådan jernbane, og for det andet fandt han den ikke påkrævet $\mathrm{p} . \mathrm{gr}$. af den trafik ad søvejen, som allerede $i$ en årrække havde fundet sted mellem Senderborg og Flensborg. ${ }^{19}$ Allerede i 1847 var der blevet etableret en dampskibsforbindelse tre gange om ugen mellem Flensborg og Sønderborg. ${ }^{20}$ Denne trafik blev udvidet, da $\gg$ FlensborgEgernsund-Dampskibsselskabet « blev oprettet i 1866, ${ }^{21}$ og trafikken steg yderligere, da dette selskab i 1875 blev sluttet sammen med det i 1874 stiftede »Sønderborg Dampskibsselskab « til "Forenede Flensborg-Egernsund-Senderborg Dampskibsselskaber «. Til belysning af denne trafik kan nævnes, at »Flensborg-Egernsund Dampskibssel- 
skab « i 1873 befordrede 13.718 passagerer og 700 tons gods mellem Flensborg og Sønderborg. ${ }^{22}$

Men Petersens jernbaneplan blev imidlertid ikke til noget. I Flensborg var man ikke tilfreds med, at en sådan bane kom til - som det hedder i Flensburger Nachrichten for 20. maj 1873 - »at gå i en bue udenom hertugdømmet Slesvigs betydeligste by «. Og der fortsættes med at understrege, at sagen ikke kan være ligegyldigt for Flensborg, men at magistraten tværtimod ikke har noget vigtigere at gøre end at sætte sig $\mathrm{i}$ forbindelse med den sønderborgske jernbanekomité. Flensborgs indbyggeres opmærksomhed må henledes på den truende fare, som denne jernbaneplan frembyder.

Men jernbanespørgsmålet kom dog ikke videre denne gang, og der skulle endog komme til at gå omtrent en halv snes år, før der atter kom skred i denne sag. Dette skete i 1882, og det skyldtes for en stor del landboforeningerne i Sundeved, som i dette år afholdt en række velbesøgte møder, hvor man så godt som enstemmigt besluttede at anmode Sønderborg kredsdag om at arbejde på at fremskynde bygningen af jernbanen Sønderborg-Tinglev.23

I 1882 nedsatte bystyret i Sønderborg sig så som en komité, der skulle undersøge mulighederne for en bane til Tinglev, og dette betegnede Sonderburger Zeitung 3. juli som et meget vasentlig fremskridt $\mathrm{i}$ banesagen. Men såvel fra statens som fra Flensborgs side var man kun interesseret $i$ en bane til Padborg. Den sønderborgske handelsstand så imidlertid $\mathrm{i}$ en sådan bane en fare for, at Flensborg skulle udvide sit opland på Sønderborgs bekostning. Man anmodede bykollegierne om at sende en deputation til trafikministeren i Kiel for at lægge et godt ord ind for Tinglev-banen; men deputationen filk dog kun halvt løfte om, at der fra linien til Padborg kunne blive bygget en forbindelse til Tinglev - en plan som byen ikke kunne gå med til. ${ }^{24}$

I 1884 havde Sønderborg kreds så en forhandling med ministeriet for offentlige arbejder, og denne forhandling gav anledning til, at man sendte et andragende til ministeren om, at Tinglev-banen måtte blive bygget. Ministeren erklærede sig rede til at lade forarbejderne foretage, såfremt de pågxldende kredse ville bidrage med 1.000 mark til omkostningerne ved et sådant arbejde. Dette skete, og forarbejderne blev udført, ${ }^{25}$ og herefter ventede man naturligvis, at banen ville blive bygget $i$ en ikke alt for fjern fremtid. Dette havde man 
så meget mere grund til at tro, som minister Maybach overfor Sønderborgdeputationen havde erklæret, at byen Sønderborg mantagelig havde en forbundsfælle i ham «, da han lagde vægt på, at nye baner kom til at udmunde $\mathrm{i}$ et knudepunkt på hovedbanen, og Tinglev var jo, i modsætning til Padborg, et sådant knudepunkt.

Men det skulle komme til at gå anderledes. Trods alle de forhåbninger, som deputationen mente at kunne nære, xndrede ministeren helt sin anskuelse, efter at han havde modtaget en skrivelse fra overpresidenten, hvori denne gik ind for, at jernbanen ikke skulle gå fra Sønderborg til Tinglev, men at den fra Søgård på den påtænkte linie skulle føres mod syd til den lille og ubetydelige holdeplads Padborg.

I efteråret 1885 forelå ministerens betænkning. Heri hedder det, "at der samtidig med drøftelsen af en bane til Padborg kunne tages under overvejelse, om der ikke skulle bygges en sidebane fra Søgård til Tinglev, for at adgangen til Sønderborg kreds kunne blive lettet så meget som muligt, således at der derved kunne skabes de bedste muligheder for at fremme erhvervslivet i denne kreds«.

Ministerens forslag kom den 30. dec. 1885 til behandling i Sønderborg kredsdag, som så den 7. jan. 1886 tog den beslutning at afvise forslaget om en bane til Padborg, såfremt der ikke samtidig blev bygget en bane til Tinglev. Det blev yderligere vedtaget, at man var rede til at yde 150.000 mark, samt frie jordarealer inden for kredsen. $\mathrm{Da}$ Flensborg og Ảbenrå kredsdage imidlertid fuldstændig afviste ministerens forslag og absolut ikke ville bringe noget offer, måtte jernbanesagen henlægges.

Men da der nu trods alt var ved at komme røre $\mathrm{i}$ den sonderborgske jernbanesag, begyndte Åbenrå by og Åbenrå kreds, som omfattede en stor del af området mellem Åbenrå Fjord og Flensborg Fjord, for alvor at interessere sig for sagen. At man i Ábenrå også tidligere havde været interesseret $i$ dette jernbanespørgsmål, fremgår af en længere artikel i Dannevirke for den 16. april 1889, hvor der gives en udførlig redegørelse for, hvordan repræsentanter for Ảbenrå by og kreds igennem de forløbne år havde stillet sig til den sønderborgske jernbanesag. Af denne artikel fremgår det, at sagen var blevet behandlet på et mode, som Åbenrå kredsdag havde afholdt den 25. april 1885. Her var det blevet besluttet at sende et andragende til regeringen om, at den påtænkte udbedring af landevejen mellem Sdr. Hostrup og Gråsten måtte blive udsat, indtil der var taget definitiv 
bestemmelse angående den påtænkte Sønderborg-Tinglev banes anlæg og retning.

Ved byrådsmødet i Åbenrå den 17. juli 1885 var landråd v. Lewetzau tilstede for at give oplysninger om dette jernbaneprojekt. Hans udtalelser gik overraskende nok ud på, at planen om en jernbane fra Sønderborg til Tinglev måtte betragtes som definitivt fastlagt, således at man kunne vente, at der ville blive givet tilladelse til at anlægge banen - så meget mere som den syntes at være af en vis militær betydning. Jernbanen ville komme til at passere Ladegård midtvejs mellem Felsted og Gråsten. Her ville der blive bygget en banegård, og landråden mente derfor, at det for byen Ảbenrå turde være på tide at overveje, hvorledes den kunne afvarge den skade for byen, som det utvivlsomt ville være, når jernbanen kom til at afskære flere af Ảbenrå kreds' sydlige landsbyer fra kredsbyen.

Landråden mente, at det måske ville være en fordel for Ảbenrå at tilvejebringe en forbindelse mellem denne by og Ladegård som tilslutning til Tinglev-banen, og hertil erklærede borgmester Vreden, at det var et forslag, som Åbenrå by ville overveje nærmere.

Også Åbenrå Handelsforening tog sagen op og besluttede at prøve på at gøre handelsministeren interesseret $\mathrm{i}$ planen om en forbindelse mellem Ảbenrå og Tinglev-banen. Der blev sendt en deputation til Berlin. Deputationen opnåede dog ikke at få audiens hos ministeren, men måtte nøjes med at afgive erklæring til »tre andre herrer« i ministeriet.

Hverken Åbenrå by eller Åbenrå kreds var stemt for en jernbanelinie fra Sønderborg til Padborg, og begge steder nægtede man enstemmigt at deltage i omkostningerne ved anlæg af en sådan bane, som man mente ville skade byen. Derimod ville både Åbenrå by og kreds være interesseret $\mathrm{i}$ en jernbane fra Sønderborg til Åbenrå og med en sidelinie til Tinglev. En sådan bane kunne ved hjælp af banen til Rødekro føres videre til Løgumkloster og dermed sættes $i$ forbindelse med den kommende vestbane.

Men med hensyn til udsigten til anlægget af en bane fra Sønderborg til Tinglev var det nu ikke helt så sikkert, som v. Lewetzau havde givet det udseende af. Den 29. sept. 1885 havde Handelskammeret $i$ Flensborg sendt et andragende til ministeren for offentlige arbejder, og heri anmodede man ministeren om, at han ved spørgsmålet om bygningen af en eventuel jernbane fra Sønderborg ville gå 
ind for en linie, der fra hovedbanen udgik fra et sydligere punkt end Tinglev.

Handelskammeret bemærkede, at Sønderborg ventede, at baneanlægget ville forøge byens handel og åbne et større handelsområde helt til de vestlige egne af Slesvig, og at dette bedst kunne opnås ved en bane til Tinglev, idet denne bane gav den korteste forbindelse mod vest. Men samtidig hævdedes det $\mathrm{i}$ skrivelsen, at en jernbanelinie til Padborg ville komme Als og Sundeved til gode, idet "disse distrikter har ringe interesse for en nærmere forbindelse mod nord ${ }^{26}$

Yderligere fremhævedes det, at »den regelmæssige og tilstrækkelige dampskibsfart« mellem Flensborg, Sønderborg og Åbenrå afsvækkede interessen for en hurtigere forbindelse mod nord. Endelig peges der $\mathrm{i}$ Handelskammerets skrivelse på, at Padborg-linien vil være af militær betydning, og at banen derfor bør bygges af staten.

Ved byrådsmødet i Ảbenrå den 21. jan. 1886 meddelte borgmester Vreden, at jernbanedirektør Mathiesen og ingeniør Kæsar fra Flensborg havde været $\mathrm{i}$ Ảbenrå for at sætte sig ind $\mathrm{i}$ jernbaneprojekterne. De havde udtalt, at der var så stærk modstand mod SønderborgPadborg projektet, at det nxppe ville blive realiseret, og hvad Rødekro-Løgumkloster projektet angik, da ville staten i hvert tilf $x$ lde ikke indlade sig på at deltage $i$ et sådant anlæg, bl. a. fordi denne bane ville komme til at ligge kun ca. $13 \mathrm{~km}$ nord for banen fra Tinglev til Tønder.

Imedens arbejdedes der videre med jernbaneprojektet SønderborgTinglev. At også Tønder var interesseret $i$, at denne linie blev bygget, fremgår bl. a. af, at Tønder magistrat og bykollegium den 4. dec. 1885 - og senere igen den 1. maj 1888 - sendte en skrivelse til minister Maybach, og heri påpegedes ønsket om, at denne bane blev bygget. Den ville blive den bedst tænkelige forbindelse mellem Tønder og Sønderborg, og ved den påtænkte bane til Højer ville jernbanen yderligere få en overordentlig gunstig afslutning både mod øst og mod vest. Skrivelsen betoner desuden kraftigt, hvorledes Tønder ved denne bane ville kunne få produkter som korn, træe, stenkul, mursten $\mathrm{m}$. v. langt billigere fra Sønderborg end fra Flensborg. ${ }^{27}$

Omtrent samtidig med den forste skrivelse fra Tønder indsendte W. Grimm den 26. december en skrivelse til Sønderborg kredsdag for at påpege nødvendigheden af, at der blev bygget en jernbane fra Sønderborg til Tinglev. I denne skrivelse beklages det dybt, at mini- 
steren foretrækker en bane fra Sønderborg til Flensborg og ikke vil give koncession på en bane fra Sønderborg til Tinglev. »Hertil siger jeg - omend med tungt hjerte - så hellere ingen, end anlæg af en bane, som for os vil være financielt og erhvervsmæssigt selvmord", og »når Padborg ikke kan afværges, så er der for os så meget større foranledning til at spare vore penge «. Og Grimm slutter med at skrive: "I henhold til ovenstående beder jeg om, at kredsdagen vil afvise enhver medvirken til Sønderborg-Padborg banen - også med en sideline til Tinglev - men derimod give kredsjernbanekommissionen pålæg om at tage sagen om anlægget af en jernbane fra Sønderborg til Tinglev ved kredsens egne midler op til nærmere overvejelse ${ }^{28}$

Ved Ảbenrå kredsdags møde den 1. sept. 1886 forelå der en opfordring fra jernbanekomiteen i Sønderborg om at deltage $i$ en forhandling om dette projekt. Under de drøftelser, der fandt sted $i$ den anledning, stod det klart, at der for Åbenrå kreds kun kunne være tale om at deltage $\mathrm{i}$ anlægget, hvis banen kom til at gå over Gråsten til Tinglev, og at der fra Gråsten blev ført en sidebane til Åbenrå. Der blev i øvrigt ved denne lejlighed henvist til, at Åbenrå kreds, hvis denne sidebane blev anlagt, kunne fritages for udbygningen af bilandevejen fra Sdr. Hostrup til Gråsten - et arbejde der var anslået at ville koste 90.000 mark.

På dette møde blev der så nedsat et udvalg, som skulle forhandle med den sønderborgske jernbanekommission. Resultatet af disse forhandlinger blev forelagt på Åbenrå kredsdags møde mere end et år senere, den 29. dec. 1887. Det meddeltes her, at Sønderborg stadig holdt på linien til Tinglev, og at denne linie også, som ovenfor nævnt, havde fundet forkæmpere $\mathrm{i}$ Tønders bystyre. Men udvalget kunne ikke anbefale Åbenrå kreds at deltage i dette jernbaneprojekt, da en sådan jernbane kun kunne være af interesse for en lille del af kredsen, og at den $\mathrm{i}$ øvrigt sikkert ville være til skade for Ảbenrå by. Derimod gik både Åbenrå byråd og kredsdagen atter ind for en jernbane Sønderborg-Åbenrå-Løgumkloster med sidelinie til Tinglev. ${ }^{29}$

I Sønderborg kredsdag bevirkede den afvisende holdning, som Åbenrå og Flensborg kredsene indtog over for banesagen, at man følte, at man i dette spørgsmål stod $i$ et mistrøstigt afhængighedsforhold af disse nabokredse. Derimod mente man, at man var herrer $i$ sit eget hus med hensyn til det forslag om anlæg af jernbane på Als, 
som i 1887 var blevet fremsat i kredsdagen. Der blev bevilget penge til forarbejderne til en smalsporet ø-bane, og i 1896 vedtog kredsdagen derpå, at denne bane skulle bygges.

Men også i denne sag skulle det komme til at gå helt anderledes, end Sønderborg kredsdag havde ventet. Den 20. maj 1888 måtte kredsdagen behandle en skrivelse fra ministeriet, efter hvilken Alsbanen skulle medtages $i$ projektet om en fastlandsbane, og det blev betonet, at banen ikke skulle være smalsporet, men have den normale sporvidde.

Planen om en jernbane, der fra Nordborg skulle gå over Sønderborg til Tinglev, havde iøvrigt været fremsat 10 år tidligere, idet den tyske ingeniør E. Dreessen i 1878 i sit skrift om sekundærbaner fremsatte forslaget om en sådan bane. Angående denne bane mente Dreessen dog, at den livlige skibsfart langs kysten ville tage så meget af trafikken, at en bane af 2 . klasse vanskeligt ville kunne forrente sig, medens en bane af 3 . klasse under alle omstændigheder ville være livskraftig.

Skibsfarten langs kysten spillede efterhånden en vis rolle. Det fremgår af, at de Forenede Flensborg-Egernsund-Sønderborg Dampskibsselskaber, som nu også havde en regelmæssig trafik fra Sønderborg til Åbenrå, i 1886 befordrede 36.397 passagerer og 1.435 tons gods mellem Sønderborg og Åbenrå, og 14.335 passagerer og 4.500 tons gods mellem Flensborg og Sønderborg. ${ }^{30}$

I sit svar af 23 . juni 1888 på ministeriets skrivelse anmodede kredsdagen om, at den - førend en afgørelse blev taget - gerne ville have besked om forskellige forhold, og desuden onskede den at fà ordet »normalsporet« strøget $\mathrm{i}$ forbindelse med Als-banen.

Som svar på dette erklærede ministeren sig for det første rede til at tage under overvejelse, at der blev bygget »en statslig udbygning * af en normalsporet jernbane Padborg-Sønderborg til Nordborg med færgedrift over Alssund, såsnart de respektive interesserede havde erklæret sig parat til at afgive de nødvendige arealer og at betale 400.000 mark. For det andet ville ministeren tage spørgsmålet om en forbindelsesbane fra et egnet punkt på Sønderborg-Padborg banen til Tinglev under nærmere overvejelse, når de interesserede kredse »i gerning « - ved at overtage de dem pålagte udgifter - havde vist deres interesse for at få bygget denne bane.

Sønderborg kredsdag var langtfra tilfreds med dette svar, som på 
ganske væsentlige punkter afveg fra de synspunkter, som kredsdagen havde fremsat $i$ sin skrivelse af 23. juni 1888. Blandt andet havde ministeren ikke givet nogen begrundelse for, hvorfor han ikke havde taget hensyn til kredsdagens beslutning om at stryge ordet »normalsporet « for Alsbanens vedkommende, ligesom skrivelsen heller ikke var gået ind på kredsdagens krav om, at der samtidig med bygningen af Padborg-banen skulle føres en bane fra Søgård til Tinglev. ${ }^{31}$

Men kredsdagen besluttede sig alligevel den 27. marts 1889 til at godkende ministerens udkast, idet man dog vedtog at gentage det tidligere fremsendte andragende om, at der nu, efter at resultatet af forarbejderne til Als-banen var blevet kendt, kunne vælges smalspor for denne bane, ligesom man gentog anmodningen om, at bygningen af banen til Tinglev kunne ske samtidig med bygningen af banen til Padborg.

Og med dette svar, der udgjorde et kompromis mellem det, som ministerens skrivelse gik ind for, og det som kredsen anmodede om, mente kredsdagen, at der kunne næres begrundet håb om, at kredsens baneløse tid nu snart ville være forbi.

Men det viste sig altsammen at være forgxves. De forhandlinger, som Sønderborg kredsdag førte med nabokredsene, gav et nedslående resultat. Både Åbenrå kreds og de to Flensborg kredse (Flensborg kreds var blevet delt $i$ en bykreds og en landkreds) ${ }^{32}$ afviste fuldstændig enhver medvirken til såvel Padborg- som Tinglev-banen, medens Tønder kreds, gennem hvis østligste del det sidste, lille stykke af banen til Tinglev skulle gå, var parat til at yde bistand.

Det kan ikke undre, at man i Sønderborg kredsdag efterhånden var ved at tabe tålmodigheden. For at prøve på at sikre sig ministerens velvilje foreslog nogle af kredsdagens medlemmer, at man skulle sende en deputation til overprxsidenten for at bede om igangsættelse af projektet om en bane fra Nordborg over Sønderborg til Padborg og med sideline til Tinglev. Men på det kredsdagsmøde den 14. dec. 1889 , hvor forhandlingerne om dette forslag skulle indledes, forelagde formanden en bekendtgørelse fra overpresidenten, hvoraf det fremgik, at Padborg-banen skulle bygges først, og inden der kunne være tale om banen til Tinglev. Overpræsidentens bekendtgørelse bestemte endvidere, at hvis Flensborg og Åbenrå kredsene ikke ville bringe det forlangte offer for Padborg-banen, blev det Sonderborg kreds' opgave at søge at få bragt en ordning i stand med disse kredse 
angående deres bidrag til omkostningerne ved jernbanebyggeriet. På kredsdagen virkede overpræsidentens skrivelse fuldstændig lammende. Man syntes, at der fra kredsdagens side var vist meget stor imødekommenhed; men man var klar over, at det var umuligt at opfylde de fordringer, der var blevet stillet, og frygtede nu, at der under disse omstændigheder næppe ville blive tale om nogen jernbane med det første. ${ }^{33}$

I 1889 var jernbanespørgsmålet ganske naturligt også blevet drøftet ude $\mathrm{i}$ landdistrikterne $\mathrm{i}$ Sønderborg kreds. Den 2. april havde denne sag således været genstand for debat $\mathrm{i}$ Ullerup. ${ }^{34}$ De deltagende landmænd viste ikke megen interesse, når lige undtages dem, gennem hvis marker jernbanen skulle gå, og disse landmænd modsatte sig på det bestemteste bygningen af en jernbane. Men særlig bemærkelsesværdigt var det dog, at nogle af sønderborgerne udtalte frygt for, at en jernbane ville være til skade for byen.

Denne opfattelse blev af banens modstandere begrundet med, at Sønderborg med sin gode havn så absolut var den naturligste og vigtigste handelsplads for hele Als og Sundeved, idet landbrugsprodukterne skulle leveres eller sælges $\mathrm{i}$ denne by. Hvis der nu kom en jernbane, så ville der ved hver station blive oprettet storre eller mindre forretninger, og leveringen af landbrugsprodukterne ville komme til at foregå på de forskellige stationer. Også rent nationalt var der nogle, der så en fare ved en jernbane. "På de forskellige steder kommer der en del importerede tyske funktionærer, der ville bidrage til at fremme fortyskningen og navnlig give stødet til indførelse af tysk gudstjeneste $\mathrm{i}$ kirkerne ". Modstanderne af en jernbane pegede desuden på, at Als og Sundeved er de områder i hele Slesvig-Holsten, der med de mange havne og anlægspladser for såvel damp- som sejlskibe har den bedste og letteste forbindelse med omverdenen, og de mente også, at hvis banen kom, ville Sønderborg rykke de større byer nærmere, og det var jo of te set, at når man anlagde en jernbane, tilrev de større byer sig handelen på de mindre byers bekostning. ${ }^{35}$

Forsvarerne for banen hævdede derimod, at Sønderborg ville blive den nærmeste købstad for hele egnen ud til i nærheden af Søgaard. »Gråsten kan pakke sammen. Hele Sundeved vil komme i nærmere forbindelse med Sønderborg på Gråstens bekostning «. Man gik ud fra, at Sønderborg ville tage en stor del af oplandet fra Ảbenrå, og mente, at egnen helt hen til Felsted, Tumbøl, Tråsbøl og Kværs ville 
foretrække denne billigere, hurtigere og mere bekvemme befordring med jernbanen, fremfor at køre ad de ofte meget dårlige veje til Åbenrå. ${ }^{36}$

Men nogen tid efter skete der en ny udvikling $\mathrm{i}$ jernbanesagen. Den 30. jan. 1890 var der indkaldt til møde i Sønderborg kredsdag, for at man kunne tage stilling til et nyt projekt, som var blevet fremsat af Flensborg, og som gik ud på, at linien Sønderborg-Padborg ikke, som man havde projekteret, skulle gå over Bojskov og Søgård, men at den efter at have forladt grænsen for Sønderborg kreds skulle gå i sydlig retning over Gråsten og Rinkenæs til Padborg. ${ }^{37}$ (Fig. 2).

Den 15. feb. afholdtes der et med spænding imødeset møde i Sønderborg kredsdag. ${ }^{38}$ Der forelå meddelelse om, at ministeren lovede at imødekomme kredsens ønsker om en linie til Tinglev, forudsat at kredsen betalte 100.000 mark samt garanterede fri grund til jernbaneanlægget, ikke blot inden for Sønderborg kreds, men også for anlægget gennem de andre kredse. Som nævnt havde Tønder amt lovet at give fri grund inden for sit område, men nu forelå den overraskende nyhed, at Åbenrå kreds nogle dage før dette møde ligeledes havde vedtaget at give fri grund. Betingelsen for denne pludselige ændring $\mathrm{i}$ Åbenrås holdning var dog, at jernbanen kom til at gå over Gråsten.

På dette møde i Sønderborg kredsdag blev det endvidere kraftigt understreget, at regeringen stod fast på, at fastlandsbanen og Alsbanen skulle behandles som et uadskilleligt hele.

På mødet fremkom der en række andre forslag og også nogle ændringsforslag, men ved de afstemninger, der blev foretaget, blev alle de fremsatte forslag med hensyn til Sønderborgs jernbaneforbindelse med omverdenen forkastet. Dermed var hele spørgsmålet muligvis skudt ud $i$ en uvis fremtid. Det var dog en ganske uholdbar påstand, at det, som det hed i et indlxg i Hamburger Nachrichten, skulle være de danske kredsdagsmedlemmer, der var skyld i dette udfald af sagen. ${ }^{39}$ Grimm, der selv var medlem af kredsdagen, gendriver da også meget kraftigt denne påstand, som han betegner som en fabel. ${ }^{40}$

Den 30. maj 1891 rejste Hans Lassen, Lysabild, i den preussiske landdag spørgsmålet om Sønderborgs jernbaneforbindelse med hovedbanen. Han begyndte sin tale, der bringes i sin fulde ordlyd i Dannevirke for den 9. og 10. juni 1891, med at give en historisk oversigt over jernbanespørgsmålets udvikling. 
Efter kort at have omtalt perioden fra 1884 og til 1887, da forhandlingerne havde været ved at gå i stå, nævnte Lassen, hvorledes der i 1890 skete det, at Flensborg bykreds bevilgede 100.000 mark til jernbaneanlægget. Til denne bevilling knyttede Flensborg dog den betingelse, at jernbanen ikke blev ført over Søgård, men at den ved kredsgræxnsen skulle føres over Gråsten og videre over Tørsbøl. Også denne plan synes jernbanebestyrelsen at have godkendt. Den erklxrede sig villig til at anlxgge banen til Padborg og samtidig en linie fra et egnet punkt på denne bane til Tinglev.

Der ville altså nu, udtalte Lassen, blive tale om, at der skulle anlægges ikke én, men to linier på fastlandet med en samlet længde af ca. $58 \mathrm{~km}$ samt ca. $42 \mathrm{~km}$ jernbane på Als, selv om den virkelige trang ville være afhjulpet ved en jernbane fra Sønderborg til Tinglev.

"Man har kunnet trakke rundt med os, mest kun fordi overpræsidenten absolut vil sætte sin vilje igennem《, erklærede Lassen, og betegnede den store plan med både fastlands- og Als-bane som et svært misgreb. Og videre udtalte han, at "Når jernbanebestyrelsen sætter os stolen for døren og siger: "Så mange jernbaner skal I have, og så mange penge skal I betale, ellers får I intet «, da sxttes vi i et tvangsforhold $\times$.

Sønderborg kredsdag, sagde han videre, ville ikke gå ind på den store plan, og samtidig udtalte den sig bestemt imod, at linien skulle læagges over Gråsten. I det hele taget fastholdt kredsdagen den oprindelige linie over Bojskov og Søgård til Tinglev, og dermed var sagen gået fuldstæendig $\mathrm{i}$ hårdknude. Hans Lassen håbede, at han ved at stille sit forslag om jernbanen til Tinglev atter kunne bringe røre i sagen. "Sønderborg kreds er den eneste i provinsen SlesvigHolsten, der ikke har nogen jernbaneforbindelse «.

Men Hans Lassens ønske om, at »det høje hus ikke uden videre ville forkaste hans forslag « blev ikke opfyldt. Umiddelbart efter, at han havde sluttet sin lange tale, stillede en deputeret forslag om overgang til dagsordenen, og da dette forslag var vedtaget, trak Hans Lassen sit forslag tilbage, uden at det var kommet til nogen som helst drøftelse eller afstemning om det. .1 $^{2}$

I Sønderborg var man efterhånden ved at blive utålmodig over, at der ikke skete noget positivt i jernbanesagen, og i december 1891 indgav ca. 250 borgere samt byens handelsforening et andragende til magistraten om, at bykollegierne ville virke for, at Tinglev-banen 
blev bygget - enten på statens bekostning eller som et privatforetagende.42

Den 30. juni 1892 besluttede Sønderborg kredsdag så at anmode ministeren for offentlige arbejder om, at der blev bygget en jernbane fra Sønderborg over Bojskov og Søgård til Tinglev. Dette bevirkede, at Ảbenrå kredsdag på et møde den 21. juli 1892 vedtog, at formanden, landråd v. Bonin, skulle sende ministeren en skrivelse, hvori der - under henvisning til, at udførelsen af dette projekt ville skade Åbenrås og navnlig Gråstens vitale interesser - anmodedes om, at en sådan jernbane kun ville blive bevilget, såfremt den blev ført over Gråsten.43

Den 29. april 1894 kom så loven om, at der skulle anlægges en af staten bygget sekundxrbane fra Sønderborg over Gråsten og Tørsbøl til henholdsvis Padborg og Tinglev, og såvel Sønderborg by som kreds måtte nødtvunget gå med til denne, mod deres ønsker stridende linieføring.

Den 20. april 1896 besluttede Sønderborg kredsdag at bevilge de 400.000 mark, der var forlangt, samt fri afståelse af de inden for kredsen nødvendige jordarealer, hvis værdi var ansat til 100.000 mark.44

Anlxgsarbejderne til banen blev påbegyndt i 1899, og den 15. juli 1901 sendtes det første tog fra Sønderborg over Tørsbøl til Tinglev. Samme dag åbnedes banestrækningen Tørsbøl-Padborg for trafikken. (Fig. 2). ${ }^{45}$

\section{Broager-banen}

Den sidste statsbane, der blev bygget i Nordslesvig i den tyske tid, var den sidebane, som satte Broager Land i forbindelse med Sønderborg-Tinglev/Padborg banen.

Tanken om at få anlagt en jernbane til Broager var kommet frem i 1898, da forbindelsesbanen og småbanerne på Als var vedtaget. Den 21. dec. 1898 sendte Håndværkerforeningen i Broager et andragende til Sønderborg kredsdag om, at der måtte blive anlagt en smalsporet bane, der fra Skelde skulle gå over Iller, Broager, Nybøl og Stenderup til V. Sottrup, hvor den ville få forbindelse med statsbanen; men på kredsdagsmødet den 30. jan. 1899 blev dette andragende afvist. 
Sagen var så stillet $\mathrm{i}$ bero indtil 1904, da kredsdagen på mødet den 20. marts måtte behandle et fra kommunerne Broager, Skodsbøl, Smel, Stenderup og V. Sottrup indgivet andragende om en lignende jernbane, men denne gang dog med den forskel, at der søgtes om en normalsporet bane og yderligere med den tilføjelse, at Snogbæk og Blans ansøgte om, at banen måtte blive forlænget til Blans. Sagen gik videre til den kongelige jernbanekommission, som den 24. juni 1904 sendte landråden i Sønderborg en skrivelse, hvori man udbad sig udtalelser om banelinien fra de kommuner, den kunne komme til at berøre, således at man derigennem kunne få et materiale, der kunne tjene til belysning af banespørgsmålet. De pågxldende kommuner var Skelde, Gammelgab, Dynt, Iller, Mølmark, Broager, Egernsund, Skodsbøl, Smøl, Nybøl, Stenderup, V. Sottrup, Snogbxk og Blans.

Det spørgeskema, som landråd v. Tschirschnitz sendte disse kommuner, omfattede ialt 11 punkter, hvis besvarelse kunne give et godt billede af erhvervsforholdene m. m. de pågældende steder. Der ønskedes oplysning om, hvilken retning den daværende persontrafik fortrinsvis tog, om håndværk og industri, jordbundsforhold, dyrkede kornarter samt om skovareal. Endvidere ønskede man at få et skøn over, $\mathrm{i}$ hvilket omfang de varer, som indtil nu havde været sendt ad landevejen eller ad søvejen, kunne forventes at ville blive sendt med den nye bane. Endnu vanskeligere måtte besvarelsen af punkt 7 i spørgeskemaet forekomme. Heri ønskedes der nemlig oplysning om, hvilken betydning den forbedrede forbindelse med andre steder ville have for en udvidelse af de bestånde virksomheder og eventuelt oprettelsen af nye, og hvor stor godstransport og transport af kvæg, der kunne forventes at komme på den nye bane.

Resultatet af kredsdagens overvejelser blev, at den i april 1905 besluttede at anmode regeringen om, at der måtte blive iværksat forarbejder til en jernbane, der fra Blans eller V. Sottrup gik til Broager og eventuelt til Egernsund og Iller. En bane til Egernsund var dog sikkert, efter hvad Sonderburger Zeitung for den 17. april 1905 skrev, ikke meget sandsynlig, da den store godsmængde fra de mange teglværker her var henvist til den billigere søtransport. Ved skrivelse af 13. maj 1905 til landråden blev der da også givet tilladelse til at lade foretage forarbejderne til en sidebane over Broager til V. Sottrup, og den 15. aug. 1910 kunne den $12 \mathrm{~km}$ lange jernbane, der på Broager Land fik endestation i Skelde, åbnes for trafikken. ${ }^{46}$ 


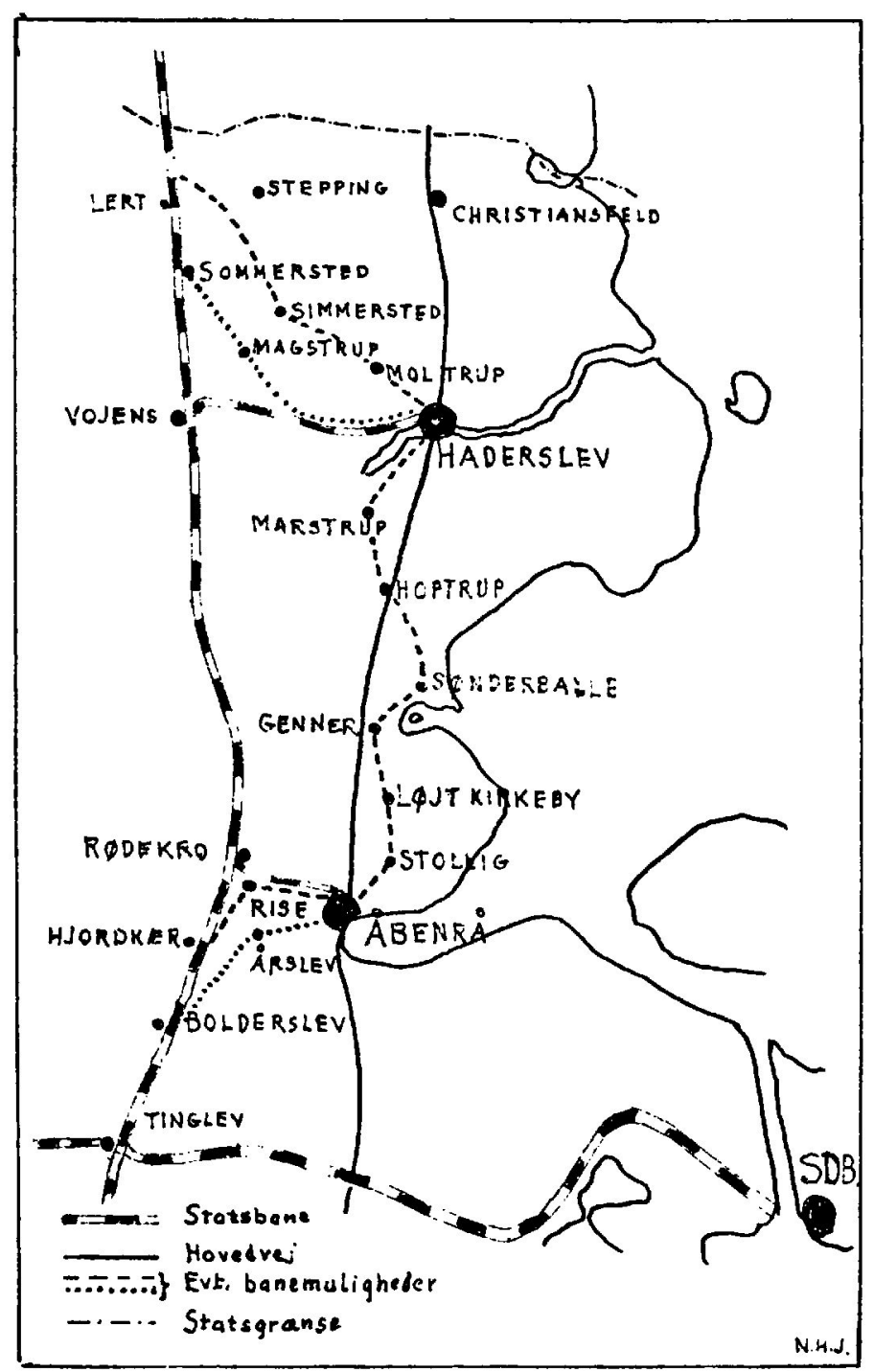

Fig. 3. Planerne for en ostkystbane 1911 med angivelse af de kommuner, bvor det blev palagt grundejerne at tillade jernbanedirektionen $i$ Altona at foretage forarbejder pa deres jord til banebygningen. Christiansfeld, Vojens, Rødekro og Tinglev var dog undtaget berfra. 


\section{Østkystbanen}

Med åbningen af banen fra V. Sottrup til Skelde var så bygningen af de nordslesvigske jernbaner tilendebragt; men debatten om jernbaneanlæg var stadig levende adskillige steder i Nordslesvig. Den fra mange sider udtalte store utilfredshed med, at den østlige længdebane var anlagt et stykke vest for Ảbenrå og Haderslev, var på ingen måde blevet mindre med årene, og det gjorde, at man $\mathrm{i}$ disse byer længselsfuldt ventede på, at der skulle ske en forandring med hensyn til deres jernbaneforbindelse. Allerede i 1901 havde man i Haderslev gjort forsøg på at få længdebanens linieføring xndret således, at hovedbanen kunne komme til at gå igennem denne by. Anledningen til, at man foretog dette skridt var, at det $\mathrm{i}$ året 1900 var blevet bestemt, at grænsetoldstationen, der var placeret i Vojens, skulle flyttes mod nord, måske til den danske grænsestation Vamdrup. Dette bevirkede, at Haderslev Handelsforening $i$ en skrivelse, som man den 19. jan. 1901 sendte til Handelskammeret i Flensborg, ${ }^{47}$ foreslog, at grænsetoldstationen ikke, som påtænkt, flyttedes til Vamdrup, men derimod til Sommersted, og at der i forbindelse hermed blev foretaget en ændring af hovedbanens forløb, således at den fra Sommersted ikke, som tilfældet nu var, fortsattes direkte til Vojens, men derimod fortes over Haderslev. Herfra skulle det bestående skinnelegeme så benyttes til Hammelev, hvorfra hovedbanen skulle føres videre over Over Jerstal. Vojens ville derved ganske vist blive en ubetydelig station. Handelsforeningens skrivelse slutter med, at man indtrængende anmoder Flensborgs Handelskammer om at fremføre denne sag på højeste sted. Olav Christensen har dog sikkert ret, når han betegner forslaget om en sådan forlæggelse af jernbanen som sen lokal ønskedrøm. ${ }^{48}$

Anderledes forholdt det sig derimod med ønsket om at få en såkaldt "østkystbane «, d.v.s. en jernbane der fra Flensborg gik over Åbenrå og Haderslev til Christiansfeld, hvorfra den så skulle føres til Kolding. ${ }^{49}$ Der syntes faktisk en tid at have været udsigt til, at en sådan bane ville blive bygget.

Som nævnt i Sønderjyske Årbøger 1975, side 80, er det fra tysk side blevet hævdet, at danskerne havde bygget »højderygsbanen « for at skade østkystbyerne. Trümpener mener derfor, ${ }^{50}$ at det, da Nordslesvig var blevet en del af det tyske rige, burde have været Preussens 
opgave at »styrke de byer, der havde lidt skade ved dette baneanlæg, ved at bygge en østkystbane, som forbandt dem med det gammeltyske land og derved styrkede det tyske sindelag i Nordslesvig«. »En østkystbane i begyndelsen af 1870 'erne«, skriver han, "ville have skabt en så snæver trafikforbindelse mellem Nordslesvig og det øvrige rige, at det ville have styrket den økonomiske og - $\mathrm{i}$ forbindelse med et stort anlagt kulturarbejde - tyskhedens åndelige overvægt, således at den politiske udvikling $i$ "Nordmark « ville have forløbet på en væsentlig anden og for hele vort fædreland mere gunstig måde. Undladelsessynderne fra dengang har ikke kunnet afhjælpes."

Planerne om en østkystbane dukkede for alvor frem i 1911 »fra højere sted “ ${ }^{48}$ Meningen var som nævnt, at der skulle bygges en jernbane Flensborg-Ābenrå-Haderslev-Kolding; men på den generalforsamling, som den 11. juni 1911 holdtes i Haderslev Handelsforening, og hvor det eneste punkt på dagsordenen var: $»$ Den projekterede kystbane«, tænkte man sig, at liniens forløb skulle være FlensborgÅbenrå-Haderslev-Ãrøsund, en plan som allerede den 24. feb. var blevet loseligt drøftet $\mathrm{i}$ Handelsforeningen. På generalforsamlingen blev det meddelt, at der $i$ en henvendelse til den danske trafikminister og til Assens byråd var blevet henvist til de $\mathrm{i}$ den danske rigsdag tidligere, allerede i 1899,51 fremsatte planer om en bro over Lille Balt, eller endog en tunnel under dette farvand. "Men «, hedder det $\mathrm{i}$ denne skrivelse, ved den foreslàede linie [over Årosund-Assens] kunne begge dele undgås «. ${ }^{47}$ De danske Statsbaner havde svaret, at de betragtede denne linie som en konkurrent til linien Gedser-Warnemünde. Landdagsmand Kloppenborg-Skrumsager havde dog lovet at støtte sagen, såfremt den kom frem i den preussiske landdag.

Dette skete imidlertid ikke. Fra den preussiske minister var der gennem overpresidenten kommet det svar, at en bane FlensborgÅbenrå-Haderslev-Årøsund ikke var påtænkt.

Men ved bekendtgørelse af 31. maj 1911 havde distriktsudvalget $i$ Slesvig givet jernbanedirektionen i Altona tilladelse til at lade foretage forarbejderne »til bygning af en statslig hovedbane fra et egnet punkt på banestrækningen Tinglev-Rødekro over Ảbenrå og $\mathrm{Ha}$ derslev til et egnet punkt på strækningen Vojens-Sommersted «.52 Forløbet af den påtænkte bane var altså ikke fastlagt i enkeltheder; men $\mathrm{i}$ bekendtgørelsen blev grundejerne $\mathrm{i}$ de kommuner, som man regnede med, at banen muligvis ville komme til at gå igennem, for- 
pligtet til at give tilladelse til, at der på deres jord blev foretaget de forarbejder, der var nødvendige for projektet. De pågældende kommuner lå i et bælte, der fra Hjordkær gik over Rise til Ảbenrå og herfra videre over Stollig og Løjt Kirkeby til Genner. Fra Genner fortsattes der over Sønderballe, Hoptrup og Marstrup til Haderslev. Jernbanen skulle i så tilfxlde føres over Haderslev Dam på en dæmning. ${ }^{33}$ Et udvalg, der arbejdede med sagen, havde planer om at få den indre del af Dammen opfyldt, således at banegården kunne anlægges der. ${ }^{54}$ Den strækning, der skulle undersøges videre mod nord, kunne komme til at omfatte 1) Moltrup, Simmersted, Stepping og Lert eller 2) Magstrup og Sommersted. Efter en supplerende bekendtgørelse, der kom den 20 . juni s. å., skulle forarbejderne $i$ den sydlige del af projektet foruden de allerede nævnte steder yderligere omfatte en strækning fra Bolderslev over Årslev til Åbenrå. (Fig. 3). ${ }^{\mathbf{5 5}}$

Men planerne om en østkystbane blev mødt med modstand fra beboerne i den vestlige del af Haderslev kreds, og i foråret 1912 blev der $\mathrm{i}$ disse egne afholdt flere protestmøder for om muligt at forhindre bygningen af denne østlige bane.

Haderslev Handelsforening besluttede alligevel at arbejde for bygningen af østkystbanen og sendte skrivelser derom både til ministeren for offentlige arbejder i Berlin og til Handelskammeret i Flensborg. I den skrivelse, som man den 21. maj 1912 sendte til ministeren, meddeltes det, hvorledes en komité fra den vestlige del af Haderslev kreds med støtte fra de vestlige kommuner havde $\mathrm{i}$ sinde at sende et andragende til den preussiske landdag angående jernbanesagen. I dette andragende ville man for det første påpege de skadelige følger, som en østkystbane ville kunne få for den vestlige del af kredsen, og man foreslog som erstatning for en sådan bane, at den nuværende jernbane udbyggedes med dobbeltspor på strxkningen fra Tinglev til Vamdrup. I skrivelsen fremhæver Handelsforeningen, hvorledes det ville være en meget stor skuffelse for Haderslev, hvis den østkystbane, som gennem en lang årrække havde været beboernes inderlige ønske, og som ville betyde så meget for byens udvikling, ikke blev til noget.

Spørgsmålet om østkystbanen satte efterhånden sindene mere og mere i bevægelse. Fra tysk side lagde man ikke skjul på den politiske betydning, som man ventede, at en østkystbane ville kunne få ved at give de godt befolkede østlige egne, og da især byerne, en bedre 
forbindelse med de sydligere områder. Dette fremgår således ganske klart af en skrivelse, som borgmester Schindelhauer, Haderslev, allerede den 19. juli 1910 havde sendt landråden i Haderslev. ${ }^{56} \mathrm{Han}$ gør her opmærksom på, hvorledes de eksisterende trafikforhold er meget sørgelige for de nordslesvigske byer. Det er, skriver han, en meget påkrævet pligt for staten, at den bygger en direkte og hurtig forbindelseslinie mod syd. En sådan jernbane, der vil betyde en snæver forbindelse med det tyske fædrelands åndelige, kulturelle og økonomiske liv, er en absolut betingelse for, at tyskheden skal kunne gå frem. Kampen for tyskheden i Nordslesvig vil være forgæves, så længe den ikke understøttes af en stadig tilstrømning fra syd. "At denne forbindelse har manglet, har $-i$ forbindelse med den fortræffeligt ledede danske agitation - bevirket, at tyskheden ikke har haft fremgang«, medens »danskheden viser et frygteligt opsving, som der ubetinget må sættes en bom for, hvis ikke Nordslesvig skal gå tabt for tyskheden «. Og det er rigtigt, at årene 1900-1914 var en rig fremgangstid for danskheden.

Fra dansk side så man naturligvis med stor skepsis på disse baneplaner, "eftersom det nu er tydeligt nok, at banen bliver bygget $i$ fortyskningsøjemed, og projektets udførelse skal påskyndes af samme grund $\kappa_{0} \mathbf{5 7}$

Iøvrigt havde jernbanedirektionen i Altona længe holdt sig tilbage m.h.t. bygningen af en østkystbane. Man var betænkelig ved at skulle anlægge en jernbane $\mathrm{i}$ det stærkt kuperede terræn langs østkysten. Jernbanedirektionen ville hellere udbygge sidebanen fra Vojens til Haderslev, således at der kunne føres hurtigtog til Haderslev. ${ }^{58}$ Men regeringen kunne efterhånden ikke se bort fra den betydning, som den omhandlede bane ville have $\mathrm{i}$ økonomisk og fremfor alt i politisk henseende, og umiddelbart før 1 . verdenskrig var der tilsyneladende udsigt til, at østkystbanen ville blive bygget. På Haderslev Handelsforenings bestyrelsesmøde den 3. marts $1914 \mathrm{blev}$ det således meddelt, at østkystbanen nu var så godt som sikret.

Verdenskrigens udbrud forhindrede, at der kunne arbejdes videre med disse jernbaneplaner. Men dette var ikke ensbetydende med, at man havde opgivet tanken om at bygge en østkystbane. Så sent som den 23. maj 1919 bragte Dannevirke en bekendtgørelse fra landråden i Haderslev, hvori det hed, at ministeriet for offentlige arbejder havde bemyndiget landmåler Pflug fra jernbanedirektionen i Altona 
til at »udføre forarbejderne ved anlæg af en jernbane fra Tinglev over Ảbenrå til Haderslev«. »Pflug har allerede begyndt dette arbejde i Haderslev «. Landråden anmoder nu kommuneforstanderne i de kommuner, der kommer $\mathrm{i}$ betragtning, om såvidt muligt at støtte Pflug $\mathrm{i}$ hans arbejde.

Til denne meddelelse bemærker redaktøren, at »det er et tydeligt tegn på, at myndighederne nu i sidste øjeblik sætter kraft ind på at gøre et arbejde for trods alt at knytte Slesvig til Tyskland. Vi kan tilføje, at det er for sent og spildt umage«.

Men nu, da afstemningstiden nærmede sig, blev der fra dansk side fremsat forslag om et lignende jernbaneprojekt.

Den 17. sept. 1919 afholdtes der i Haderslev et møde, hvor de deltagende ca. 150 reprasentanter fra østkystens byer og landkommuner gik stærkt ind for, àt der skulle bygges en østkystbane, der fra Kolding gik over Haderslev og Ảbenrå til f. eks. Tørsbøl ved banen til Sønderborg. Der havde i forvejen, den 18. marts 1919, været afholdt et møde om denne sag med repræsentanter fra handelsforeningerne $i$ Haderslev og Åbenrå.

På et møde den 17. september, der er udførligt refereret i Dannevirke dagen efter, gav driftsbestyrer Tarp, Kolding, en oversigt over den foreløbige udarbejdelse vedrørende den linieføring, som man mente, at det nye baneprojekt skulle have, og som i store træk svarede til den plan, der $\mathrm{i}$ årene for krigen var blevet udarbejdet af tyskerne.

Diskussionen om den første, og måske vanskeligste strækning fra Kolding til Taps blev udskudt til senere. Fra Taps skulle banen på det første stykke føres langs den vestlige side af Taps Å til Christiansfeld. Herfra gik den mod syd langs hovedvejen, som den skulle skære ved Rørkær, for derefter at fortsætte til Haderslev gennem Favrdalen lige øst for Haderslev. Banen ville således komme ind i Haderslev i østvestlig retning til den ved Jomfrustien liggende amtsbanegård. Fra Haderslev skulle banen så følge småbanen til Marstrup, hvorfra den via Hoptrup førtes til Genner. Herfra kunne banen føres til Ảbenrå ved enten at følge hovedvejen eller ved, at linien blev lagt over Løjt Kirkeby og Skovby. Hvis man valgte denne sidstnævnte strækning, ville banens forløb komme til at svare til småbanestrækningen fra Genner til Ảbenrå, og denne småbane måtte så falde bort.

Ved den således projekterede bane ville jernbanestrækningen Kol- 
ding-Flensborg så at sige blive den samme, ca. $100 \mathrm{~km}$, som ad den bestående hovedbane; men afstanden mellem Kolding og Haderslev ville blive forkortet med ca. $20 \mathrm{~km}$, og omtrent den samme forkortelse ville strækningen mellem Haderslev og Ảbenrå få.

På mødet var der nogen uoverensstemmelse angående en sådan jernbanelinies hovedformål. Byernes repræsentanter ønskede absolut, at en bane fra Kolding til Flensborg skulle være en statsbane, hvorpå der kunne føres eksprestog, og driftsleder Tarp, der ved mødets begyndelse havde præciseret, at man onskede en bane, hvorpå der kunne køres med en hastighed af højst $70 \mathrm{~km}$ i timen, udtalte senere, at han mente, at der godt kunne køre eksprestog på den projekterede linie. Han var dog af den opfattelse, at al gennemgående trafik mellem Danmark og Tyskland vedblivende skulle gå over statsbanen.

Landboerne stillede imidlertid andre krav til banen, idet de mente, at den fortrinsvis burde tjene de lokale interesser.

Efter genforeningen drøftede Den sønderjyske Jernbanekommission også muligheden for anlæg af en hovedbane, der kunne tilvejebringe en mere direkte forbindelse mellem Haderslev og Ảbenrå; men sagen blev opgivet, $\mathrm{da}$ en sådan bane ville kræve uforholdsmæssigt store anlægsomkostninger (ca. 30 mill. kr.)..$^{59}$

\section{Småbanerne}

At statsbanenettet faktisk var udbygget i 1901, var dog ikke ensbetydende med, at bygningen af jernbaner i Nordslesvig nu var afsluttet. Dette var langtfra tilfældet, idet det var i årene 1898-1910, at de udstrakte systemer af småbaner, der i over 30 år skulle få så stor betydning for denne landsdel, blev bygget, og det skete $i$ så stor udstrækning, at den samlede længde af disse småbaner kom til at overstige længden af landsdelens statsbaner. Ved genforeningen var der således i Nordslesvig ialt $347 \mathrm{~km}$ småbaner $\bmod 265 \mathrm{~km}$ statsbaner. (Fig. 4).

Den egentlige begyndelse til anlæg af småbaner i Slesvig skete, da der i 1884 blev givet tilladelse til anlag af den $50 \mathrm{~km}$ lange »kredsbane « fra Flensborg til Kappel; den åbnedes for driften den 1. juli 1886.

Der var før den tid blevet bygget småbaner - eller »tertiærbaner«, som de også kaldtes - enkelte steder i Tyskland; men de var ikke 


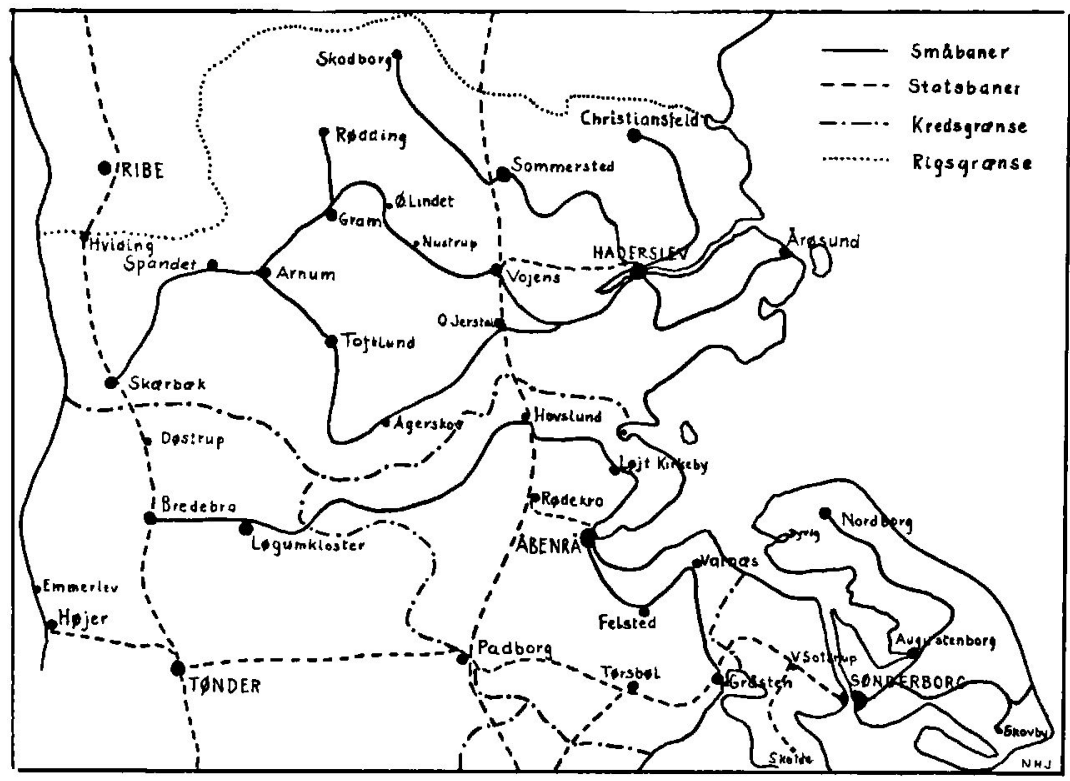

Fig. 4. De nordslesvigske jernbaner 1912.

blevet særlig godt modtaget. Man var bange for, at disse billige anlæg ikke ville give de store indtægter, og at de således kunne komme til at virke tyngende på de respektive kommuners økonomi. Men efter udstedelsen af loven af 28 . juli 1892 om småbaner ændredes forholdene helt. Udbygningen af småbaner tog nu fart, og det skete i et så stærkt tempo, at medens den samlede længde af småbaner i Preussen i 1892 kun var $160 \mathrm{~km}$, var den i 1917 steget til $11.160 \mathrm{~km} .{ }^{60}$ Særlig stærk var væksten i Nordslesvig, hvor der i de tre kredse, der havde småbaner - Haderslev, Ảbenrå og Sonderborg kredsene - i 1920 gennemsnitlig var $12,30 \mathrm{~km}$ småbaner pr. $100 \mathrm{~km}^{2}$, et tal, der måske ikke blev overgået noget sted $\mathrm{i}$ Tyskland.

Grunden til, at loven af 28 . juli 1892 animerede til den stærke vækst af småbaner, var blandt andet, at der ved denne lov blev givet større muligheder for at opnå tilskud fra stat og provins til bygning af dette samfærdselsmiddel, som man fra mange sider stillede store forventninger til, idet man var overbevist om, at småbanerne betød den forbedring af trafikforholdene $i$ landdistrikterne, som efterhånden var stærkt påkrævet. 
Formålet med småbanerne var først og fremmest at betjene den lokale trafik. Som udløbere fra statsbanenettet havde småbanerne den opgave at formidle forbindelsen videre til fjernestliggende steder, og de skulle desuden - for at opfylde bestemmelserne i småbanelovens $\$ 1$ - lægges således, at de direkte berørte så mange sogne som muligt. ${ }^{61}$ Dette betød, at småbanerne egentlig skulle træde $\mathrm{i}$ stedet for bilandevejene. Ved bygningen af disse baner drejede det sig ikke om at skabe en ny forbindelse mellem købstæderne, men om at lette forbindelsen mellem landsby og købstad. Det ville derfor "være ønskeligt, om enhver, der kører med småbanerne, gør sig det klart, at han ved benyttelsen af denne bane ikke må stille uberettigede jernbanefordringer $\ll{ }^{62}$

Men en følge af de krav, der stilledes til småbanerne, blev, at disse baners linieføring ofte blev noget helt for sig selv. Bestræbelserne for i så vid udstrækning, som muligt at kunne efterkomme landbefolkningens ønsker om at fă en jernbane igennem deres by, kunne resultere $i$, at banen fik et så stærkt bugtet forløb, at jernbanelinien mellem to endestationer blev næsten dobbelt så lang, som landevejsforbindelsen var. Som eksempel kan nxvnes, at medens den direkte forbindelse mellem Haderslev og Årøsund er $15 \mathrm{~km}$, så var længden af den småbane, der forbandt disse to endepunkter, $27 \mathrm{~km}$.

Og bedre blev det ikke ved, at der, for at landdistrikterne kunne blive betjent så godt som muligt, blev oprettet et så stort antal stationer og holdepladser, at afstanden mellem to holdesteder undertiden ikke var mere end $1,5 \mathrm{~km}$. På den $53 \mathrm{~km}$ lange jernbanestrækning, der fra Haderslev gik over Ustrup, Vojens og Gram til Rødding, var der således ikke mindre end 21 steder, hvor togene skulle holde. Det kan derfor ikke undre, at togrejsen fra Haderslev varede mellem $3^{1 / 2}$ og 4 timer.

Dette, at småbanerne på en måde skulle træde i stedet for bilandevejene, betød også, at man overalt, hvor det drejede sig om anlæg af nye bilandeveje burde undersøge, om det ikke ville være mere hensigtsmæssigt at bygge småbaner $\mathrm{i}$ stedet for. Som følge deraf kunne det ske, at bygningen af planlagte veje blev udsat, og at man så $\mathrm{i}$ stedet for byggede småbaner. ${ }^{\text {B }}$

Ved bygningen af disse lokalbaner, som måske gik til så afsides liggende steder af ren landbrugsmæssig karakter, at man ikke kunne forvente den helt store trafik, måtte man $\mathrm{i}$ første række prøve på at 
spare så meget som muligt på anlægsomkostningerne, for at banen skulle kunne forrente sig. Man byggede derfor smalsporede baner med en sporvidde på 1 meter. Herved blev anlægsomkostningerne 30$50 \%$ billigere end ved anlægget af normalsporede baner med en sporvidde på $1,435 \mathrm{~m}$, d.v.s. at bygningen af en smalsporet bane kun fordrede en lidt højere anlæagskapital end bygningen af en chaussé, men til gengxld regnede man med, at en chaussé fordrede betydeligt større vedligeholdelsesudgifter. ${ }^{64}$

De normalsporede baner med det tungere rullende materiel krævede et fastere banelegeme, og dette $i$ forbindelse med ekspropriationen af de større arealer, der krævedes, forøgede anlægsudgifterne $\mathrm{i}$ betydelig grad. Men hertil kom så den meget væsentlige omstændighed, at man med en normalsporet jernbane ikke altid kunne komme der, hvor det var muligt for en smalsporet bane at køre. De smalsporede baner kunne ikke alene klare en betydelig større stigning end de normalsporede baner; men deres mulighed for at kunne overvinde terrænvanskelighederne viste sig også derved, at de kunne tage kurver, hvis mindste radius kun var ca. halvt så stor, som radius til de kurver, der er nødvendige for de normalsporede jernbaner. ${ }^{65}$

Småbanerne skulle altså på en måde supplere statsbanerne, idet de på statsbanestationerne både modtog og afleverede gods, der skulle befordres videre. Men her viste det sig, at statsbanerne holdt sig principielt afvisende m. h. t. et snævrere fællesskab med de tilførende baner, således at udgifterne ved omladning af godset kom til at påhvile småbanerne. ${ }^{68}$ Som et eksempel på statsbanernes uvilje til samarbejde med privatbanerne kan nævnes, at der $\mathrm{i}$ Vojens måtte bygges to banegårde lige overfor hinanden - en for statsbanen og en for småbanen til Rødding.

Planerne for småbaner fandt en ivrig forkæmper $i$ jernbanedirektør Kuhrt i Flensborg, som allerede på den tid, da man var ved at bygge kredsbanen fra Flensborg til Kappel, fremsatte planen om et sammenhængende småbanenet for hele Nordmark «. Det bedste havde været, mente han, hvis enten staten eller provinsen havde taget sagen op og derved havde haft lejlighed til at udføre et større, afsluttet småbanenet, som kunne være et supplement til statsbanerne. At det var påkrævet at skaffe bedre trafikforhold i Nordslesvig, fremgår blandt andet af, at denne landsdel var ret dårligt forsynet med jernbaner. I den del af Nordslesvig, der i 1920 kom tilbage til Danmark, 
var der i 1897 kun 4,6 km jernbane pr. $100 \mathrm{~km}^{2}$. Til sammenligning kan nævnes, at på Fyn var det tilsvarende tal i dette år $9,6 \mathrm{~km}$. I den store Haderslev kreds, der strakte sig tværs over Nordslesvig fra Lille Bælt til Vadehavet var der, umiddelbart før bygningen af småbanerne blev påbegyndt, ikke mere end $3,4 \mathrm{~km}$ jernbane pr. $100 \mathrm{~km}^{2}$ og i Åbenrå kreds $4,6 \mathrm{~km}$, medens der overhovedet ikke fardtes jernbaner i Sønderborg kreds.

Men det kom ikke til at gå helt, som Kuhrt havde ventet. Hver kreds undtagen Tønder kreds byggede sine egne småbaner uden på nogen måde at prøve på at skabe forbindelse med nabokredsenes jernbaner. Særlig bemærkelsesværdigt var det, at småbanerne i Åbenrå og Haderslev kredsene på en ca. $18 \mathrm{~km}$ lang strækning mod sydvest fra stationerne Hovslund og Over Jerstal kom til at løbe omtrent parallelt på hver sin side af den fælles kredsgrænse, og det betød, at afstanden mellem de to småbaner på flere steder kun var 5-6 km.

Den tyske kgl. bygningsinspektor Paul Paap giver et meget poetisk udtryk for det uheldige forhold, at der overhovedet ikke var nogen forbindelse mellem de enkelte kredses småbanesystemer. Han sammenligner disse småbanesystemer med blomster, der står $\mathrm{i}$ hver sin krog, uden at man har fundet den dygtige hånd, der kan forene dem til en buket. ${ }^{67}$

Men det kan ikke nægtes, at de smalsporede småbaner i Nordslesvig trods alt fik en ikke ringe betydning for den lokale trafik, og der skal derfor $\mathrm{i}$ det følgende gives en kort oversigt over disse småbaners første udvikling.

Den forste smalsporede jernbane $i$ den nordlige del af provinsen Slesvig-Holsten blev som nævnt den $50 \mathrm{~km}$ lange bane fra Flensborg til Kappel, som åbnedes i 1886; men fra Flensborg kreds bredte interessen for anlæg af smalsporede baner sig hurtigt til de nordslesvigske kredse.

Til at begynde med var det, som om jernbanedirektør Kuhrts tanke om et samlet nordslesvigsk småbaneanlæg havde en mulighed for at blive realiseret. Under den langstrakte debat om forbindelsesbanen fra Sønderborg til hovedbanen havde Flensborg i 1889 meddelt, at byen ikke ville afgive nogen erklxring om bidrag til en linie Sønderborg-Padborg, og der anførtes som grund, at der var opstået et nyt projekt. Det projekt, der var kommet på tale, var anlægget af en smalsporet bane, som fra Flensborg skulle føres gennem Flensborg, 
Åbenrå og Haderslev kredsene til den danske grænse. ${ }^{68}$ Planen om bygningen af en sådan bane kom frem i Åbenrå i 1882; men Handelskammeret i Flensborg, som man bad om at gøre noget for sagen, var dengang ikke interesseret. ${ }^{69}$ Den 9. sept. 1883 sendte borgmester Vreden, Åbenrå, så en skrivelse til bykollegierne i Haderslev med meddelelse om, at der til stats- og krigsministeriet var indsendt en ansøgning om anlæg af en østkystbane fra Flensborg over Ảbenrå til Haderslev. ${ }^{70}$ Det var dog egentlig først en halv snes år senere, at spørgsmålet om en sådan bane begyndte at tage en fastere, men noget xndret form. Den 4. maj 1892 afholdtes der i den anledning i Å benrå et møde, som borgmester Vreden havde indkaldt til. På dette møde gjorde jernbanedirektør Kuhrt rede for de foreliggende planer og udtalte, at »der ved den påtænkte forbindelse gennem landdistrikterne fra Flensborg Fjord langs østkysten til grænsen kun kunne tænkes på en "sporbane«. En sporbane er overhovedet for tiden det fuldkomneste middel til en lokal samfxrdsel «. Der kunne ikke være tale om at anlægge en sekundærbane, der ville blive 3 gange så dyr m. h. t. anlæg og drift wuden samtidig på langt nær at formå at fremme den stedlige trafik «. ${ }^{71} \mathrm{På}$ et møde $\mathrm{i}$ Gråsten den 28. dec. $1892 \mathrm{blev}$ det drøftet, hvad man havde foretaget sig med dette projekt. Det blev her meddelt, at byen Haderslev havde forholdt sig afvisende over for det oprindelige projekt om at føre banen over Haderslev til Kolding. Den 9. maj 1892 havde Modersmaalet bragt en artikel, som gik stærkt imod den foreslåede »sporbane«. Det blev her fremhxvet, at en sådan bane kun ville være til gavn for Flensborg. "Skulle man her i kredsen onske en bane anlagt, ville det være ganske anderledes heldigt at forbinde vestegnen med en tværbane til Vojens «. Som sagerne lå, kunne det altså nu tilsyneladende kun komme til at dreje sig om en forbindelse mellem Flensborg og Ảbenrå.

I sit referat af Gråsten-mødet skriver Dannevirke 29. december, at Haderslev på mødet i Ảbenrå den 4. maj havde stillet sig langfra venlig over for dette projekt, og at byens repræsentanter »ikke engang var til at bevæge til at komme frem med, hvilke meninger de nærede om sagen «. "Men ", hedder det videre, "det skinnede igennem, at Haderslev havde andre projekter, som f.eks. at forbinde kredsens østlige og vestlige dele igennem en tertiærbane«.

Det var dog måske ikke helt rigtigt, at Haderslev skulle have vist sig afvisende. Et referat, som Hamburger Correspondent for 31. dec. 
1892 havde bragt om Gråsten-mødet, blev den 3. jan. 1893 sendt til Haderslev magistrat af landråden $\mathrm{i}$ Haderslev, som ønskede at vide grunden til byens afvisende holdning. I sit svar af 6 . januar udtalte magistraten, at den den 22. maj havde modtaget en tryksag angående den omhandlede tertiærbane, og denne tryksag sluttede med tilsagn om, at "komiteens næste møde ville blive afholdt i Haderslev«. Jernbanesagen blev derefter gjort til genstand for forhandlinger $i$ bykollegierne i Haderslev den 8. juli 1892, og disse forhandlinger resulterede $i$, at medlemmerne af bykollegiet skulle indbydes til at deltage $\mathrm{i}$ komitéforsamlingernes møde, når der blev indkaldt til det. "Dette kan«, slutter magistratens skrivelse, wikke være en afvisende holdning ${ }^{6} .{ }^{68}$

Men det blev altså kun banestrækningen fra Flensborg til Åbenrå, der drøftedes på mødet i Gråsten. Der var her livlig debat om denne banens linieføring. Repræsentanterne for Flensborgs Handelskammer afgav den erklæring, at banen under alle omstændigheder skulle føres over Gråsten. Da der var opnået enighed om dette, var hovedpunkterne for banen fastlagt, og efter at jernbanedirektør Kuhrt havde erklæret, at terrænvanskelighederne ikke spillede nogen rolle for småbaner, bestemtes det, at linieføringen fra Flensborg til Gråsten skulle være: Flensborg-Kruså-Hønsnap, et sted mellem Tørsbøl og Rinkenæs, -Gråsten. Linieføringen videre til Åbenrå blev: Gråsten-KidingFelsted-Sdr. Hostrup-Røllum-Ābenrå.

Efter at der $\mathrm{i}$ februar havde været afholdt møder $\mathrm{i}$ de to underudvalg, der behandlede den sydlige og den nordlige del af denne bane, afholdt Åbenrå kredsdag den 9. maj 1893 et møde om sagen. Det viste sig her, at der fra forskellige sider $\mathrm{i}$ denne by var modstand mod banen, da man mente, at landmændenes produkter ville gå over Gråsten til Flensborg. Også Handelsforeningen i Ảbenrå var imod projektet, selv om borgmester Vreden betonede, at man ved en jernbane ville lukke op for en livligere trafik $\mathrm{i}$ landdistrikterne, hvor vejene ikke længere var tilstrækkelige. ${ }^{72}$ Men baneprojektet blev alligevel ikke til noget.

\section{Als-banerne}

Det blev på Als, at de første småbaner i Nordslesvig blev anlagt. 
Selv om det var åbningen af Flensborg-Kappel banen i 1886, der for alvor bragte spørgsmålet om bygning af småbaner i Nordslesvig på tale, kan man godt sige, at tanken om muligheden for anlæg af baner af denne type var dukket op en del år tidligere.

Allerede i 1878 havde Dreessen i sin pjece om sekundærbaner blandt andet bragt et forslag om en »tertiærbane« fra Nordborg over Sønderborg til Tinglev; men det var dog egentlig først omkring 1880, at man begyndte at se på mulighederne for bygning af småbaner på Als. Ved en vejlov af 26 . feb. 1879 var det blevet bestemt, at kredsene skulle overtage udbygningen af bilandevejene, hvorefter det skulle påhvile provinsialforvaltningen at vedligeholde de af kredsen udbyggede veje. Den interesse, som regeringen havde fået for disse veje, skyldtes, at man havde indset, at bilandevejen nu, da bygningen af jernbaner vandt mere og mere frem, ville få større betydning ved at lette den lokale trafik til jernbanestationerne. ${ }^{33}$

I Sønderborg kredsdag blev det nu drøftet, om det kunne være financielt forsvarligt for kredsene at udbygge de $61 \mathrm{~km}$ bilandeveje, som det drejede sig om i kredsen. Men man skønnede, at det, da Sønderborg kreds var ret afsides beliggende, og da desuden $2 / 3$ af kredsen lå på en ø, næppe havde nogen interesse for de øvrige dele af provinsen, om der $\mathrm{i}$ denne kreds var godt udbyggede bilandeveje, ikke mindst, da trafikken til de andre kredse for en stor del var henvist til søvejen, ligesom $i$ øvrigt en ikke ringe del af trafikken inden for selve kredsen foregik ved kystsejlads. Ud fra disse betragtninger besluttede man enstemmigt, at det ikke kunne være forsvarligt at pålægge kredsen den meget betydelige udgift, der var forbundet med en udbygning af bilandevejene og afgivelsen af så meget kostbar jord til dette formål. Men bag denne beslutning lå også den tanke, at kredsen med tiden ville blive stillet over for spørgsmålene om anlæg af såvel en forbindelsesbane til provinsens jernbanenet og af småbaner, og at det så ville være godt at have sparet de penge, som bygningen af landeveje ville koste - så meget mere som de forhåndenværende biveje var fuldstændig tilstrækkelige til trafikken. ${ }^{74}$

Det var nu $\mathrm{i}$ og for sig ikke så mærkeligt, at kredsdagen var klar over, at en jernbane fra Sønderborg til hovedbanen ville komme i løbet af ikke alt for lang tid, for allerede i 1873 var man begyndt at tale om en sådan jernbane. Men man kunne ikke have ventet, at sporgsmålet om en bane på Als var blevet taget op i løbet af få år. 
Imidlertid foranledigede åbningen af småbanen fra Flensborg til Kappel og de gode resultater, som denne bane kunne opvise i det første år, jernbanedirektør Kuhrt og kgl. bygningsinspektør I. Jensen til i 1887 at fremkomme med en skrivelse om anlæg af en "sporbane* (Spurweg) på Als. ${ }^{75}$

Der nævnes $\mathrm{i}$ denne skrivelse for det første de forskellige muligheder, der havde været i Sydslesvig for anlæg af småbaner; "men “, forts $x$ ttes der, »for ingen af de hidtil opstillede projekter kan der dog stilles en så gunstig prognose som den for anlæg af en »sporbane« på Als, hvor alt, hvad der borger for en sikker rentabilitet af foretagendet, er til stede $\mathrm{i}$ rigelig målestok «. Foruden øens frugtbare jord og dens store befolkningstæthed anføres bl. a., at »badestederne Mommark, Høruphav og Augustenborg for fremtiden vil medføre en trafikudvikling, som den, der har fundet sted ved badestedet Lyksborg “.

Der opridses derefter en linieføring, der i store træk svarer til de baner, der senere kom, og det understreges, at man ved bygningen af denne bane bør bestræbe sig for at anlægge den "så tæt som muligt ved de forhåndenværende veje, øvrige skel og grænser, da grunderhvervelsen derved lettes væsentlig, samtidig med at landbruget ikke påføres store driftsgener.«

I skrivelsen er der endog foretaget nøjagtige beregninger over bl. a. taksterne, som man vil komme til at betale på denne linie, sammenlignet med de $» n u$ bestående omnibusruter «. Medens en billet for befordring med omnibus fra Sønderborg til Nordborg koster 1,50 mark, vil taksten på jernbanen blive 1,30 mark. Ligeledes er der foretaget beregninger over priserne for godstransporten. Efter disse skulle f. eks. transporten fra Sønderborg af det årlige forbrug af kul i Tandslet mejeri kun komme til at koste en fjerdedel af, hvad der nu betaltes.

Men derefter fremhæves det, at der - ud over det, at udgifterne til transport altså bliver betydeligt mindre - kommer, at besparelserne $\mathrm{i}$ tid bliver endnu større, da banen tilbagelægger strækningen ca. 3 gange så hurtigt som de eksisterende, hestetrukne omnibusruter.

"Og«, slutter skrivelsen, »ovenstående eksempler vil være tilstrækkelige til at åbne øjnene for den eminente gevinst, der er ved et sådant jernbaneanlæg «.

Efter 1892 var der flertal i kredsdagen for bygning af en jernbane til Nordborg samt en anden til det østlige Als. Denne plan støttedes 
bl. a. af gårdejer Peter Grau, Pøl ved Nordborg, der tvivlede på, om man ville være villig til at ofre penge på en sådan jernbane, når først Tinglev-banen var blevet bygget. Men planen mødte også skarp modstand, og da først og fremmest fra kredsdagsmedlem Hans Lassen, Lysabild. Hans Lassen gik meget strekt ind for bygningen af en bane til Tinglev, men mente, at man i de tider, hvor de okonomiske forhold var så dårlige, som de var, ikke burde give penge ud til mindre rentable foretagender som jernbaner på Als, og han så desuden nødigt, at de frugtbare alsiske marker blev gennemskåret af jernbaneskinner. Efter hans opfattelse ville sådanne jernbaner være en unødvendig luksus. "Man måtte ikke glemme, at hele øen var et agerdyrkende land, der var tvunget til at holde en hestebestand, som, når den skulle fuldføre det nødvendige ved jordens forarbejdning i rette tid, også nogenlunde ville være istand til at forrette den nødvendige transport og den nødvendige kørsel her, hvor det overalt kun drejer sig om forholdsvis mindre afstande ${ }^{76}{ }^{76}$ Lassen henviste endvidere til de gode dampskibsforbindelser, der var her, og forudså muligheden for, at dampskibsselskabet ville arbejde på at få anlagt endnu flere anløbssteder, og at dampskibenes lavere takster ville gøre, at en stor del af godsbefordringen gik denne vej. ${ }^{77}$

Men den 2. marts 1896 besluttede kredsdagen enstemmigt at bygge småbaner på Als og bevilgede hertil frie jordarealer til en værdi af 200.000 mark til anlægget, samt en sum på 1.400 .000 mark til bygningen af banen.78

For at opfylde bestemmelserne $\mathrm{i}$ småbanelovens $\$ 1 \mathrm{om}$, at banen $\mathrm{i}$ så høj grad som muligt skulle betjene den lokale trafik og derigennem fremme den erhvervsmæssige udvikling på øen, skulle banen fra Sønderborg planlægges således, at den for at nå øens yderpunkter blev delt ved Vollerup $i$ to grene, hvoraf den ene gik til Nordborg og den anden til Skovby. Fra denne sidste gren skulle der så føres en sidegren til det gamle overfartssted Mommark. I Jensen og Kuhrts skrivelse fra 1887 var man gået endnu videre, idet man efter den ville føre den nordlige gren helt ud til landsbyen Holm, der ligger ca. $3 \mathrm{~km}$ vest for Nordborg, $i$ nærheden af ladestedet Dyvig, lige som man efter samme skrivelse havde villet føre den sydlige gren forbi Skovby ned til den $1 \mathrm{~km}$ længere mod syd liggende Kegnæs-Gård.

Det af kredsdagen nedsatte udvalg regnede det for givet, at trods skibsfarten langs kysten ville den samlede godstrafik med få undta- 
gelser søge småbanen, og man skønnede, at der årligt ville blive transporteret ca. 19.000 tons gods og 16.000 stkr. kvæg.

$\mathrm{Da}$ man regnede med, at det $\mathrm{i}$ det mindste foreløbig ikke kunne ventes, at der ville blive bygget en direkte tilslutning til nogen anden jernbane, blev Als-banernes sporvidde fastsat til 1 meter, hvad man mente var $\mathrm{i}$ overensstemmelse med den trafik, der ville komme på denne bane. ${ }^{78}$

Den 28. sept. 1896 blev så det første spadestik på den alsiske bane taget, og efter en højtidelig indvielse, som blev foretaget af overpræsident v. Köller den 4. og 5. feb. 1898, åbnedes strækningerne fra Sønderborg til Guderup og Skovby, medens driften på strækningen fra Guderup til Nordborg blev påbegyndt den 2. juli 1898.79

Det af kredsudvalget anslåede skøn over størrelsen af gods- og kreaturtransporten på disse baner kom $\mathrm{i}$ begyndelsen til at stemme $\mathrm{i}$ forbløffende grad. I banernes tredie regnskabsår 1900/01 blev der nemlig på Als-banerne transporteret 19.234 tons gods og 16.000 stk. kvæg, ${ }^{80}$ og i løbet af de følgende år steg disse tal meget betydeligt.

Men der havde lige fra åbningen af Als-banerne meldt sig problemet om, hvorledes der kunne etableres en direkte forbindelse mellem $\emptyset$-banen og den kommende fastlandsbane, og $\mathrm{i}$ årenes løb blev der gjort store anstrengelser for at få en løsning på denne vanskelige sag. Man tænkte sig ikke alene, at en sådan forbindelse kunne tilvejebringes ved færgebåde; men kredsjernbanekommissionen fik endog i 1889 et ingeniørfirma fra Altona til at undersøge, om den $223 \mathrm{~m}$ lange pontonbroforbindelse, der havde været her siden 1856, kunne gøres så solid, at der på den kunne føres hestetrukne jernbanevogne over Alssund. Spørgsmålet om etablering af en direkte forbindelse mellem de to baner trængte sig stadig mere og mere på; men i 1903 besluttede kredsudvalget at henlægge denne sag, indtil det var afgjort, om der ville blive oprettet en marinestation i Sønderborg, og man endvidere var klar over, hvilke havneanlæg dette ville medføre. ${ }^{81}$ I 1907 blev problemet om den direkte skinneforbindelse over Alssund imidlertid igen bragt på bane; men i en skrivelse af 19. december d. å. meddelte magistraten kredsbanekommissionen, at den almindelige færdsel over pontonbroen nu var blevet så stor, at det først og fremmest gjaldt om at sikre den, og at nogle undersøgelser, der var blevet foretaget, havde godtgjort, at broen ikke kunne tage den merbelastning, som en overførsel af jernbanevogne ville medføre. ${ }^{82}$ 


\section{Småbanerne i Haderslev og Abenrå kredsene}

Omtrent samtidig med, at man var gået igang med at bygge de smalsporede baner på Als, begyndte man også på anlægget af småbanerne i Haderslev og Åbenrå kredsene.

I Tønder kreds lykkedes det derimod ikke at få anlagt småbaner, når undtages den $14 \mathrm{~km}$ lange bane fra Nibøl til Dagebøl, selv om der $\mathrm{i}$ tidens lob havde været foreslået forskellige baner. I 1877 havde der således været en plan fremme om anlæg af en smalsporet bane fra Tønder over Læk til Eggebxk på hovedbanen fra Flensborg til Slesvig, og i 1898 havde der været tale om at anlægge en lignende jernbane, som fra Tønder skulle gå over Sæd og Lydersholm til Valsbøl på den i 1889 åbnede jernbane fra Flensborg til Læk og Nibøl;83 men hverken disse planer eller det i 1904 fremsatte forslag om en jernbane, der fra Tønder skulle gå over Ravsted og Bolderslev eller Hjordkær til Åbenrå kom til udførelse. ${ }^{84}$ I øvrigt havde Handelsforeningen $\mathrm{i}$ Ảbenrå givet sin ubetingede tilslutning til planen om en småbane fra Tønder til Ảbenrå, og den beklagede sig dybt over, at planen rent ud blev afvist af landråd v. Uslar. ${ }^{85}$

Det blev altså kun i de tre østlige kredse, at der blev anlagt småbanesystemer, og af disse blev det i Haderslev kreds så afgjort det største, idet den samlede længde af småbanerne her blev $211 \mathrm{~km}$, medens der i Åbenrå kreds kun blev bygget $86 \mathrm{~km}$ og i Sønderborg kreds $50 \mathrm{~km}$ småbaner. Hertil må dog naturligvis bemærkes, at $\mathrm{Ha}-$ derslev kreds var langt den største af kredsene, idet dens areal var $1694 \mathrm{~km}^{2}$ mod det senere Haderslev amts $1369 \mathrm{~km}^{2}$, medens Åbenrå kreds kun omfattede $785 \mathrm{~km}^{2}$ og Sønderborg kreds $442 \mathrm{~km}^{2}$.

Sporgsmålet om anlæg af småbaner i Haderslev kreds, der er udførligt behandlet i Wilcke's bøger om Haderslev amts jernbaner, var den 1. feb. 1893 på dagsordenen i Haderslev Handelsforening og kom i den følgende tid gang på gang til debat dér. ${ }^{86}$

Omtrent på samme tid blev der gjort et alvorligt forsøg på at få anlagt en lokalbane $i$ den midterste del af Nordslesvig. Planen gik ud på at få bygget en nord-syd-gående jernbane mellem de to længdebaner. På et møde i Rødding den 4. marts 1893 drøftedes forskellige forslag; men det vedtoges at lade en komité arbejde for et af den meget ansete gårdejer J. N. H. Skrumsager, Københoved, fremsat forslag om en tertiærbane, der fra et passende sted på den danske 


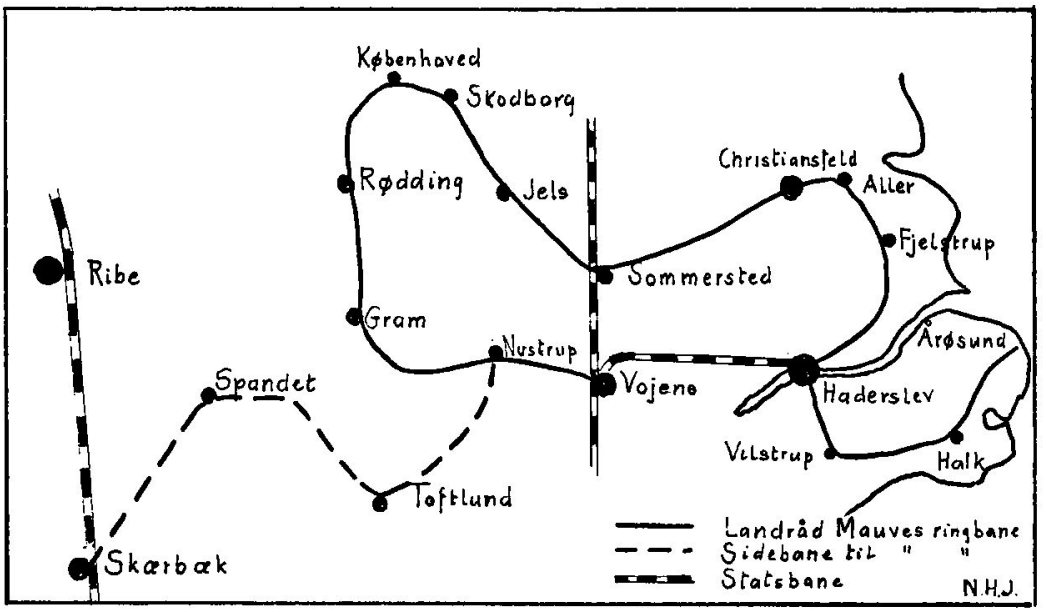

Fig. 5. Landråd Mauves planer til en ringbane i Haderslev kreds fra 1892.

tværbane fra Fredericia til Esbjerg skulle gå over Rødding, Gram og Toftlund til Bylderup Bov. Fra Gram skulle der så bygges en sidelinie til Vojens. ${ }^{87}$

Dr. Karl Mauve, der var blevet landråd i Haderslev i 1892, havde imidlertid, da planerne om en midtbane begyndte at tage form, søgt at skabe større interesse om bygningen af småbaner, der gik ud fra Haderslev, og en af kredsdagen nedsat kommission anmodede jernbanedirektør Kuhrt om at undersøge, hvorledes forholdene var for anlæg af småbaner i Haderslev kreds. $\mathrm{På} \mathrm{grundlag} \mathrm{heraf} \mathrm{fremsatte}$ Mauve så sin plan om jernbanebygning. Han havde fået den idé, at opgaven bedst kunne løses ved, at der blev bygget en kreds-ringbane med forbindelse til havnen i Årøsund. Banens forløb skulle være: Haderslev-Fjelstrup-Christiansfeld-Hjerndrup-Sommersted-Oksenvad-Jels-Skodborg-Københoved-Rødding-Gram-Kastrup-NustrupVojens. Fra Nustrup skulle der så bygges en bane, der over Toftlund og Arnum og Spandet gik til Skærbæk. ${ }^{88}$ (Fig. 5).

De hovedsagelig danske kredse, der stod bag midtbaneprojektet, var langt fra tilfredse med landrådens forslag, og på et møde i Rødding den 29. maj 1894 forkastedes Mauves plan blankt. 
Den af kredsdagen nedsatte kommission foreslog så den 10. feb. 1896 kredsdagen at begynde jernbanebyggeriet med to mindre baner, nemlig 1) Haderslev-Fjelstrup-Christiansfeld og 2) Sommersted-JelsRødding; men stemningen på landet var dog absolut for en bane fra Vojens over Gram til Rødding.

Også Haderslev Handelsforening var imod baneplanerne. På et møde den 15. feb. 1896 havde man udtalt, at det, som det i første rakke kom an på, var at få besejlingsforholdene til Haderslev forbedret, og at der ikke kunne være tale om bygning af jernbaner, før uddybningen af fjorden var afsluttet, og man havde fået havneforholdene bragt $\mathrm{i}$ tilfredsstillende stand. Når Handelsforeningen således stod forrest $i$ kampen for at få besejlingsforholdene til Haderslev forbedret, skyldtes det, at man var klar over, at byen i den henseende stod svagt i forhold til Åbenrå og Flensborg, og man beklagede, at disse to byer så ofte blev fremhævet som handelsbyer for $\mathrm{i}$ hvert fald en del af Haderslev kreds. Men man måtte erkende, at $\mathrm{Ha}$ derslev var mindre heldigt stillet, så længe fjorden ikke kunne gøre større nytte for byen, end tilfældet var. Handelsforeningen anså derfor uddybningen af Haderslev Fjord som en hovedbetingelse for, at småbaner kunne være til virkelig nytte, og at det altså burde være det, som man først gav sig i lag med.

Men landråden var af en ganske anden opfattelse. På et møde i Christiansfeld den 26. feb. 1896 udtalte han, at en uddybning af Haderslev Fjord fra 3,2 m til 5,2 m ville koste kredsen mindst 300.000 mark. Det ville desuden tage 20 år at få fjorden uddybet, og når det var sket, så ville den hurtigt mudre til igen.

De følgende dage var præget af flere, meget bevægede møder. ${ }^{89}$ Den febrilske iver, hvormed der arbejdedes på at få en lossning på jernbanesagen, gjorde, at Handelsforeningen med kort varsel indkaldte til generalforsamling den 21. marts, for at man kunne drøfte det foreliggende forslag om en jernbane, der fra Haderslev skulle gå over Vojens og Gram til Rødding. På Handelsforeningens møde den 15. februar var det blevet udtalt, at det store vestlige opland næsten var gået tabt for byens handelsstand på grund af de dårlige forbindelser. På generalforsamlingen blev der nu vedtaget en resolution til kredsdagsmedlemmerne, og heri blev det betonet, at den nxvnte linie ville være »den heldigste forbindelse mellem byen og dens store vestlige opland «; men "hele linien fra Rødding til Haderslev bør bygges 
samtidig, da dette efter vort skøn er mest formålstjenligt for hele kredsen «.

Den stærke mødeaktivitet, der havde været, endte med, at kredsdagen den 28. marts 1896 vedtog et ændringsforslag, der gik ud på, at der $\mathrm{i}$ stedet for den plan, som var blevet fremsat den 10. februar, om at der skulle bygges en bane fra Sommersted over Jels til Rødding, nu skulle bygges en jernbane, der fra Haderslev førtes over Marstrup, Vojens og Gram til Rødding.

Med hensyn til linieføringen for den anden jernbane, der var blevet foreslået den 10. februar, nemlig banen til Christiansfeld, viste der sig meget stor uenighed. Christiansfeld forlangte pludseligt, at denne bane ikke, som foreslået, skulle gå over Fjelstrup, men at den skulle følge den »direkte linie « ved at gå over Neder Åstrup, Stendetgård og Errested, og altså på en stor strækning ville komme til at følge hovedvejen fra Haderslev til Kolding. Men dette forslag, som muligvis skyldtes de næringsdrivende $\mathrm{i}$ byerne, blev dog forkastet til fordel for Fjelstrup-linien. Banens betydning skulle særlig ligge $i$, at den skulle være en hjælp for landbruget, og Fjelstrup-linien kom jo netop til at gå igennem en udmærket landbrugsegn.

Drøftelsen af linieføringen for banen fra Vojens til Rødding bød ikke på store vanskeligheder, men da man $\mathrm{i}$ Kastrup viste sig helt uinteresseret $i$ dette foretagende, blev banen ført $i$ en stor bue over $\varnothing$ ster Lindet og Vester Lindet. Dette bevirkede det ejendommelige, at banen derved kom til at gå ind til Gram og Gramby nordfra. Fra Gramby måtte den så tilbage over Gram for at komme til Radding. ${ }^{90}$

Den 4. marts 1899 blev banen fra Haderslev til Christiansfeld åbnet for driften, og dagen efter begyndte trafikken på banen fra Vojens til Rødding, medens den strækning, der fra Haderslev gik over Ustrup til Vojens, blev åbnet den 4. dec. 1899.

I de drøftelser, der havde fundet sted om disse baneanlæg, havde der ikke alene været strid mellem danske og tyske, men der havde også undertiden været splittelse mellem såvel danskerne som tyskerne indbyrdes. Resultatet var blevet et kompromis, som medforte, at alle faktisk var utilfredse med det meste $o g$ ingen helt tilfredse med noget. Men endnu førend jernbanen til Christiansfeld var blevet færdig, havde landråden den 23. feb. 1898 forelagt kredsdagen forslag om bevilling til forarbejderne på folgende banelinier: 


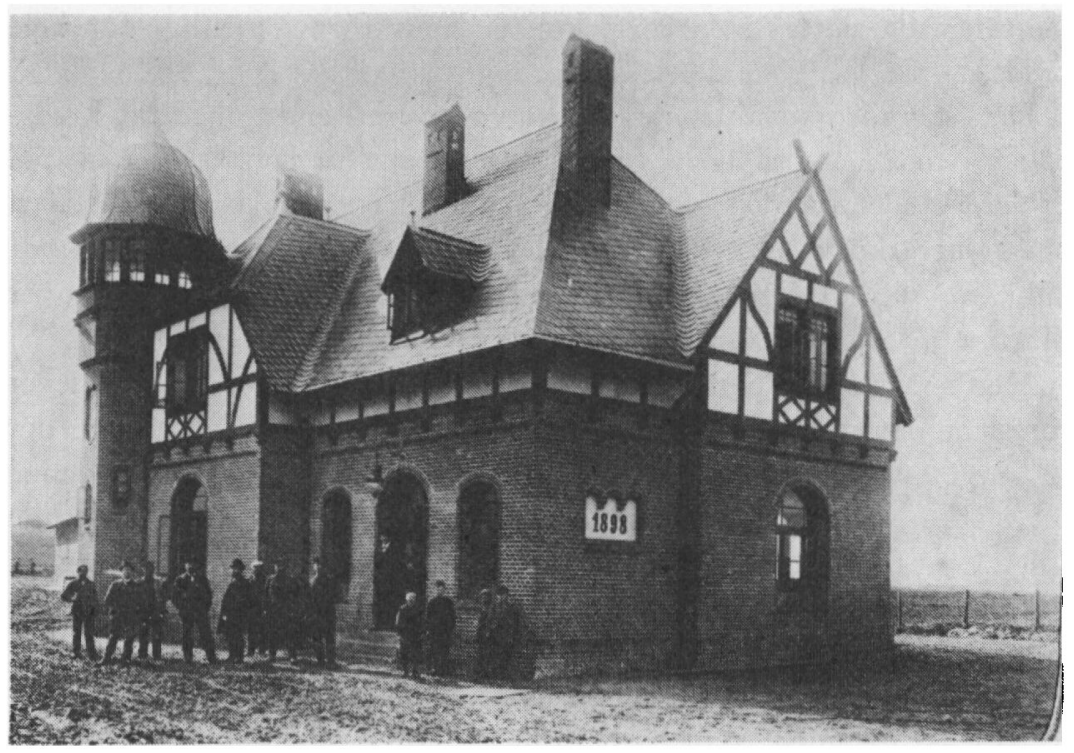

Gram station, et eksempel $p d$ landråd Mauves prangende stationsbyggeri $i$ Haderslev kreds. (Haderslev bybistoriske arkiv).

1. Haderslev-Sommersted-Skodborg

2. Gram eller Toftlund-Arnum-Skærbæk

3. Ustrup-Over Jerstal-Toftlund

4. Haderslev-Ãrøsund

Efter lange og besværlige forhandlinger i 1898 var regeringen gået med til, at sejlløbet i Haderslev Fjord kunne uddybes til 5,3 m. Under behandlingen af denne sag i den preussiske landdag havde finansministeren $i$ øvrigt motiveret sin anbefaling af sagen med at fremhæve den betydning, som forbedrede besejlingsforhold ville have for tyskhedens vækst i Haderslev. ${ }^{91}$ Der blev dog stillet den betingelse for, at uddybningsarbejdet kunne foretages, at såvel byen som kredsen skulle yde et tilskud på 100.000 mark, og at der fra privat side blev fremskaffet 30.000 mark. Magistraten anmodede derfor Handelsforeningen om blandt sine medlemmer at søge at vække interesse for havnesagen og navnlig opfordre til ved tegning af bidrag at støtte sagen. Foreningen gjorde dette ved bl. a. at foreslå mejerierne $\mathrm{i}$ kredsen, at de tegnede sig for et tilskud på 50 pfg. pr. ko, som hørte til mejeriet. 
I den skrivelse, som Handelsforeningen sendte til mejerierne, hedder det: "Al den forretning, som på lige betingelser tilføres kredsbyen, forøger dennes ydeevne til gavn for hele kredsen, hvorimod al den forretning, der naturligst burde drages til kredsbyen, men som på grund af den dårlige vandvej ikke kan ske uden skade for vedkommende og derfor må gøres andet sted, svækker byens ydeevne til skade for hele kredsen ${ }^{92}$ Henvendelsen bar dog ikke frugt, idet "kun 2 mejerier ydede bidrag: Stepping med 100 mark og Gl. Haderslev mejeri med 150 mark $\times .{ }^{.3}$

I Ảbenrå så man med meget stor uvilje på, at der nu skulle foretages så store arbejder for at forbedre besejlingsforholdene til Haderslev, og den 16. jan. 1899 vedtog Handelsforeningen i Ảbenrå, at der over for Handelskammeret i Flensborg skulle protesteres mod bevillingen til uddybningen af Haderslev Fjord. Som motivering for denne protest anførtes det blandt andet, at Haderslev havde et tilstrakkeligt stort opland, og at denne by ved oprettelse af en kort jernbane over Genner ville kunne få udmærket forbindelse med Åbenrå havn, samt at Haderslev kreds iøvrigt havde gode havne ved Årø og Kalø. ${ }^{94}$

Men uddybningen af Haderslev Fjord blev gennemført $\mathrm{i}$ årene 1899-1901, og resultatet af dette arbejde viste sig snart. Medens omsxtningen i Haderslev havn i 1900 havde været 17.959 tons og 7.600 $\mathrm{m}^{3}$ termmer, var den i 1909 steget til 62.081 tons og $11.163 \mathrm{~m}^{3.95}$

Og da uddybningen var blevet påbegyndt, og de første småbaner var blevet åbnet i 1899, kom der skred i jernbaneplanerne. Den 30. juni 1899 fremsatte kredsbanekomiteen forslag om, at der i stedet for de den 23. feb. 1898 foreslåede baner blev bygget følgende baner:

1. Haderslev-Årøsund

2. Skrydstrup-Bevtoft-Rangstrup-Agerskov-Toftlund

3. Haderslev eller Christiansfeld-Sommersted-Skodborg

I drøftelserne om disse forslag kom jernbanelinien til Årøsund til at indtage en særstilling, og årsagen hertil var dette steds specielle beliggenhed, der gennem århundreder havde gjort Årøsund til et meget vigtigt overfartssted fra Sønderjylland til Fyn.

Allerede den 29. aug. 1899 begyndte man at udstikke jernbanelinien til Årøsund, og den 28. maj 1903 kunne denne bane indvies. Imidlertid var der sket det, at der allerede, da bygningen af Ãrøsund-banen 
var blevet påbegyndt, var kommet andre planer frem, idet man i 1899 var begyndt at forhandle om anlæg af en normalsporet bane her i forbindelse med åbningen af en færgefart mellem Årøsund og Assens. ${ }^{96}$ Den 6. nov. 1899 blev der i Assens afholdt et møde om denne sag, og blandt mødedeltagerne var der også repræsentanter fra Haderslev Handelsforening. Landråd Mauve var velvillig indstillet overfor planerne, men på den betingelse, at banen kom til at berøre Haderslev, og den 19. april 1900 henvendte kredsens repræsentanter sig så til det preussiske indenrigsministerium med en anmodning om bygning af jernbanen Årøsund-Haderslev-Rødekro.

Men den 2. aug. 1900 forelå indenrigsministerens klare afvisning af den fremsatte plan. Dette blev dog ikke ensbetydende med, at planen om en normalsporet bane $i$ forbindelse med en færgeforbindelse blev skrinlagt. I 1902 begyndte man nemlig igen at arbejde med sagen. Den 8. april mødtes repræsentanter for Haderslev med landråd Becherer $\mathrm{i}$ spidsen og medlemmer af Assens byråd på færgegården $\mathrm{i}$ Årøsund. Becherer var interesseret $\mathrm{i}$ projektet, men mente, at man skulle have en normalsporet bane til Haderslev.

Forhandlingerne i de følgende år førte dog ikke til noget. I februar 1904 lykkedes det ganske vist Becherer at få dannet et konsortium i Haderslev kreds med den opgave at anskaffe en dampfarge til en forbindelse Årøsund-Assens; men det lykkedes ikke at få Assens købstad og det konsortium, der ejede Årøsund færgegård, til at indskyde det beløb på henholdsvis 3.000 og 1.000 mark, som var en betingelse for, at planen om en færgerute kunne blive realiseret.

Becherer blev dog ved med at arbejde med planerne. I september 1905 anmodede han jernbanedirektør Kuhrt om at undersøge, hvorledes mulighederne for at indrette en færgehavn ved Årøsund var. Der skete dog ikke noget videre, og da Becherer i 1908 blev forflyttet til Berlin, faldt planerne bort; men som tidligere nævnt dukkede interessen for denne færgeforbindelse atter op i 1911, da debatten om en østkystbane begyndte at komme på tale.

Den næste jernbane, der åbnedes i det efterhånden ret udstrakte småbanenet i Haderslev kreds, var Toftlund-banen, hvor driften blev påbegyndt den 2. april 1904.

Den 30. juni 1899 havde jernbanekommissionen som omtalt fremsat forslag om en bane, der fra Skrydstrup skulle gå over Bevtoft og Rangstrup til Toftlund. Imidlertid viste det sig, at Skrydstrup kom- 
mune ikke ville betale noget som helst til denne Toftlund-bane, og det endte derfor med, at kredsdagen gik ind på et af Vedsted kommune fremsat forslag om at lade en bane til Toftlund udgå fra Ustrup på småbanestrækningen Haderslev-Vojens.

Og året efter, den 1. juli 1905, kunne så indvielsen af den sidste af de småbaner, der udgik fra Haderslev, finde sted. Det var jernbanen til Skodborg. Der havde været megen diskussion om denne banes linieføring, men efter at der på et møde i Sommersted den 30. juli 1903 havde vist sig meget stærk stemning for en jernbane fra Haderslev over Sommersted til Skodborg, vedtog kredsjernbanekommissionen denne bane. ${ }^{97}$ Regeringen var meget interesseret $i$ bygningen af jernbane gennem denne næsten helt danske egn; men man kunne på forhånd skønne, at der ikke var særlig lyse udsigter for en sådan banes økonomi. Grunden hertil var, at banens opland var ret begrænset, idet den første del af strækningen kun var ca. $7 \mathrm{~km}$ sydvest for banen til Christiansfeld, og på strækningen fra Sommersted til Skodborg $i$ en lignende afstand fra banen til Rødding. Og mod nord var den ganske txt ved landegrænsen.

Hermed var bygningen af smalsporede baner omkring Haderslev faktisk afsluttet; men nogle år senere kom der dog et par ganske betydelige udvidelser af Haderslev kreds's småbanenet, idet der den 15. sept. 1910 blev åbnet to baner fra henholdsvis Toftlund og Gramby til Arnum og den 13. november samme år en bane fra Arnum til Skærbæk. ${ }^{98}$ Der var således nu etableret den gennem årene så ofte foreslåede forbindelse mellem Haderslev og den vestlige del af $\mathrm{Ha}-$ derslev kreds. Den direkte forbindelse mellem Haderslev og Skærbæk - en tur, der tog 41/2 time - kom til at gå over Over Jerstal, Toftlund og Arnum. ${ }^{99}$

Det kan ikke nægtes, at Haderslev kreds dermed havde fået et småbanesystem, som med sin samlede længde af $211 \mathrm{~km}$ i meget høj grad opfyldte de fordringer, som jernbaneloven af 1892 stillede til denne type af jernbaner, idet småbanerne nu strakte sig $i$ alle retninger fra Haderslev ud i den store kreds. Men fra mange sider blev der udtalt stor utilfredshed med de dyre anlæg og den store gæld, som derigennem blev påført kredsen. Utilfredsheden gjaldt ikke mindst de unødvendigt store stationsbygninger, der opførtes mange steder. I en omtale af landråd v. Tschirschnitz, Sønderborg, skriver H. P. Hanssen således: „De kredsbaner, der er bygget i Sønderborg kreds, skæmmes 
ikke af vilde projekter som dr. Mauves kostbare stationsbygninger i Haderslev kreds\&. ${ }^{100}$

I Ảbenrå kreds blev småbanenettet derimod ikke udviklet helt så heldigt som i Haderslev og Sønderborg kredsene. En medvirkende årsag hertil var blandt andet, at Åbenrå kreds ikke alene efterhånden havde fået længere statsbanestrækninger end de andre kredse, men også at statsbanestrækningerne inden for Åbenrå kreds gik i både nord-sydlig som vest-østlig retning.

I slutningen af 1800-tallet var der blevet fremsat forskellige planer om småbaner i Åbenrå kreds. I 1889, da spørgsmålet om en tværbane var stærkt på tale, havde Åbenrå Handelsforening arbejdet for en baneforbindelse mellem Rødekro og Løgumkloster. I 1893 var den samme forening gået stærkt imod planen om anlæg af en småbane fra Åbenrå til Gråsten og foreslog $\mathrm{i}$ stedet for, at kredsen skulle arbejde for en bane mod vest over Branderup til Skærbæk. Samtidig anbefalede Åbenrå Handelsforening den i 1893 fremsatte plan om en tertixrbane fra Rødding over Toftlund til Bylderup Bov med sidelinie fra Bedsted til Rødekro. Interessen for en jernbane fra Åbenrå til Vestslesvig viste sig også ved, at Handelsforeningen i 1897 gik helt ind for en bane fra Åbenrå til Ballum. ${ }^{101}$

Men resultatet af arbejdet for at få småbaner i Abenrå kreds blev, at der kun blev bygget to banelinier, som på grund af statsbanernes forløb $\mathrm{i}$ kredsen $\mathrm{p}^{\circ}$ en måde blev henvist til ret nøje at følge kredsens nordlige og østlige grænselinier og derved fik nogle linieføringer, som på forhånd måtte dømme banerne til urentabilitet.

Den 14. feb. 1899 åbnedes småbanen fra Ảbenrå til Gråsten for driften. Som så mange andre af småbanerne fik denne bane et noget ejendommeligt forløb. Fra Ảbenrå kunne den ret let føres nogenlunde direkte over Sdr. Hostrup til Felsted, men da den herfra skulle nå op til Varnæs, måtte den lige øst for Felsted bøje mod nordøst over Skovbøl. Fra Varnæs gik jernbanelinien faktisk lige mod syd over Kiding til Gråsten. Resultatet af dette næsten S-formede forløb blev, at Ảbenrå-Gråsten banen blev $31 \mathrm{~km}$ lang, medens den lige afstand mellem de to byer kun er ca. $20 \mathrm{~km}$.

Den 8. maj 1901 åbnedes så den $55 \mathrm{~km}$ lange småbane fra Åbenrå til Løgumkloster. Denne bane fik et forløb, som grev Erik Schack med rette betegner som rekorden $i$ retning af vanvittig linieføring “. ${ }^{102}$ Fra Åbenrå blev denne bane nemlig ført mod nordøst - med 


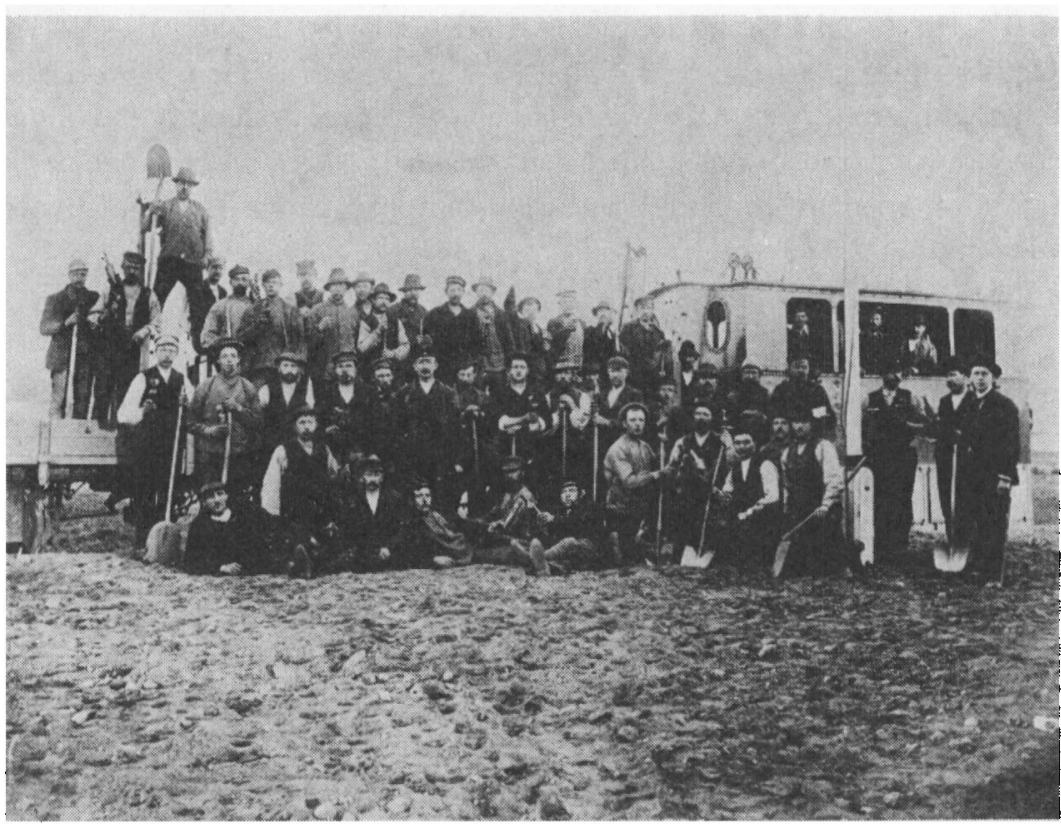

Fra anlagget af amtsbanen Abenra-Gråsten, der abnedes 1899.

(Historiske Samlinger for Sønderiylland).

forskellige bugtninger og på en bro over vejen, der fra syd fører til Stollig, ind i det kuperede Løjt Land. På de første $5 \mathrm{~km}$ måtte banen arbejde sig op til en højde af ca. $60 \mathrm{~m}$ over havet ved landsbyen Stollig. Herfra fortsattes banen så over Løjt Kirkeby til Genner, idet den på strækningen fra den nuværende Genner Hule rasteplads til Lyngtofte Kro løb umiddelbart langs østsiden af hovedvejen mellem Ảbenrå og Haderslev. Fra Genner gik banen så først over Øster Løgum til Hovslund og derfra med hovedretningen vest-sydvest til Løgumkloster. Men man havde altså opnået, at forbindelsen med de vestlige egne af kredsen var blevet etableret, selvom det havde været et ret kostbart foretagende for Ảbenrå kreds.

Det er indlysende, at de tre nordslesvigske kredse havde udført et meget betydeligt arbejde og ofret sxerdeles store beløb på bygningen af småbanerne, og det er bemærkelsesværdigt, at disse store anlægsarbejder blev fuldført $\mathrm{i}$ løbet af en ganske kort årrække. Bortset fra de ialt $39 \mathrm{~km}$ lange banestrakninger fra Toftlund og Gram til Arnum 
og derfra til Skærbæk, som blev fuldført i 1910, blev alle de tre kredses småbanestrækninger, ialt $308 \mathrm{~km}$, bygget i tiden 1898-1905. $\mathrm{Da}$ bygningen af de smalsporede baner var blevet afsluttet i 1910, var der $\mathrm{i}$ de tre kredse som helhed gennemsnitligt $12,3 \mathrm{~km}$ småbaner pr. $100 \mathrm{~km}^{2}$, medens der i den øvrige del af provinsen Slesvig-Holsten var $3,9 \mathrm{~km}$ pr. $100 \mathrm{~km}^{2}$

\section{Jernbanernes erbvervsøkonomiske betydning}

Efter den stærke udvikling, som de nordslesvigske jernbaner havde gennemgået ved bygningen af småbanerne og ved anlægget af jernbanen fra Vester Sottrup til Skelde, havde Nordslesvig i 1910 nået den maksimale lengde af jernbaner, og landsdelen havde fået en jernbanetæthed, der var ganske bemærkelsesværdig. Der fandtes i den del af Slesvig, som i 1920 blev genforenet med Danmark, ialt $592 \mathrm{~km}$ jernbaner.

Det vil være naturligt at sammenligne jernbanetætheden i Nordslesvig med forholdene, som de i 1920 var i Danmark nord for Kongeåen. Det viser sig da, at medens der i det genforenede $-3964 \mathrm{~km}^{2}$ store - Nordslesvig ialt var $14,9 \mathrm{~km}$ jernbane pr. $100 \mathrm{~km}^{2}$, var det tilsvarende tal for Danmark uden Nordslesvig $10,9 \mathrm{~km}$. Og tager man jernbanetxtheden $i$ forhold til indbyggertallet, ser man endnu tydeligere, $i$ hvor høj grad Nordslesvig var forsynet med jernbaner $i$ forhold til det øvrige Danmark, idet der i Nordslesvig var $36,0 \mathrm{~km}$ jernbane pr. 10.000 indbyggere, medens det tilsvarende tal for det ovrige Danmark kun var $16,4 \mathrm{~km}$.

$\mathrm{Da}$ Nordslesvigs ret store jernbanetxthed $\mathrm{i}$ høj grad skyldtes de mange småbaner, som i Haderslev kreds udgjorde 78,4 \% af kredsens samlede jernbanelængde og i Åbenrå og Sønderborg kredsene henholdsvis $57,0 \%$ og $63,4 \%$, må det først og fremmest blive småbanernes betydning, der vil blive omtalt i det følgende.

Som tidligere nævnt havde anlæggelsen af småbanerne været en meget kostbar sag for de tre kredse. Selv om udgifterne ved bygningen af denne specielle type af jernbaner var 30-50\% mindre end ved anlæg af en normalsporet jernbane, måtte kredsene dog betale 10 mill. mark, og det bidrag, som staten og provinsen havde ydet, var på lidt over 8 mill. mark. ${ }^{103}$ Dette betød, at kredsene ved bygningen af disse småbaner pådrog sig meget betydelige gældsposter. Ingen af 
kredsene kunne til stadighed forrente den i småbanerne investerede kapital, og udgifterne til småbanerne udgjorde ofte næsten halvdelen af kredsens budgetterede skatter. ${ }^{104}$ Dette gjaldt i særlig grad Haderslev kreds, hvor udgifterne til småbanerne blev så store, at denne kreds »efterhånden opnåede at blive en af de mest forgxldede $\mathrm{i}$ hele det preussiske monarki «. ${ }^{105}$ Som regel klarede Als-banerne sig bedre, selv om disse baner bl. a. måtte kæmpe med de vanskeligheder og den bekostning, som var forbundet med, at de var uden direkte forbindelse med fastlandsbanen. Dette betød, at gods, som fra Als-banerne skulle viderebefordres med fastlandsbanen, skulle transporteres pr. vogn over pontonbroen, og efter vognmandstakst kostede dette 8 mark pr. ton. ${ }^{106}$

Men selvom bygningen af småbaner således forceredes frem over evne, er der ingen tvivl om, at de på mange måder blev til virkelig gavn for kredsene, idet de ofte åbnede adgangen til vidtstrakte landområder, hvor trafikforholdene havde været vanskelige. Men småbanernes betydning kunne utvivlsomt have været langt større, hvis de ikke var blevet bygget således, at der overhovedet ikke var nogen forbindelse mellem de tre kredses småbanesystemer.

Den udvikling, som disse baner gennemgik, kan illustreres ved de grafiske fremstillinger. (Fig. 6). Det fremgår heraf bl.a., at den befordrede godsmængde gennemgående steg stærkt i tiden fra 1900 til 1913, det sidste normale år før verdenskrigen. Det, der vel nok falder mest $\mathrm{i}$ øjnene, er den meget stærke stigning, som godstransporten på småbanerne i Haderslev kreds gennemgik, idet disse baner i 1913 transporterede ca. 7,4 gange så meget gods som i 1900, medens der på småbanerne i Åbenrå kreds og på Als-banerne i 1913 transporteredes henholdsvis ca. 5,6 og 3,2 gange så meget gods som i 1900.

Men for at kunne foretage en sammenligning af transportudviklingen $\mathrm{i}$ de tre kredse er det, da længden af småbanerne i Sønderborg og Åbenrå kredsene var uforandret fra henholdsvis 1898 og 1901, medens småbanenettet i Haderslev kreds først var fuldt udbygget i 1910, da dets samlede længde var over 3 gange så stort som i 1900, nødvendigt at se på, hvorledes størrelsen af gods- og passagertrafikken pr. jernbanekilometer udviklede sig på de forskellige småbanesystemer. Det viser sig da, at medens der i 1900 transporteredes omtrent lige meget gods pr. banekilometer på de tre småbanesystemer, var godstransporten i 1913 absolut størst på Als-banerne. Den meget betyde- 

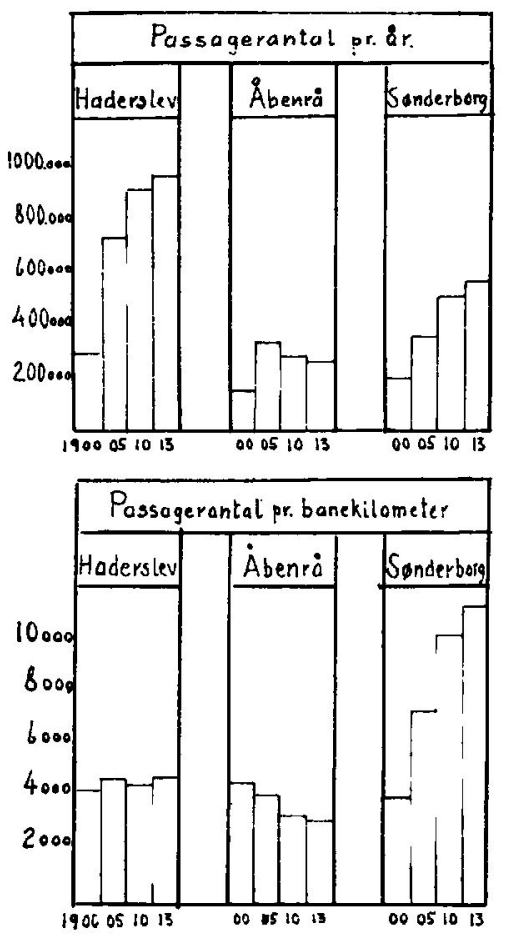
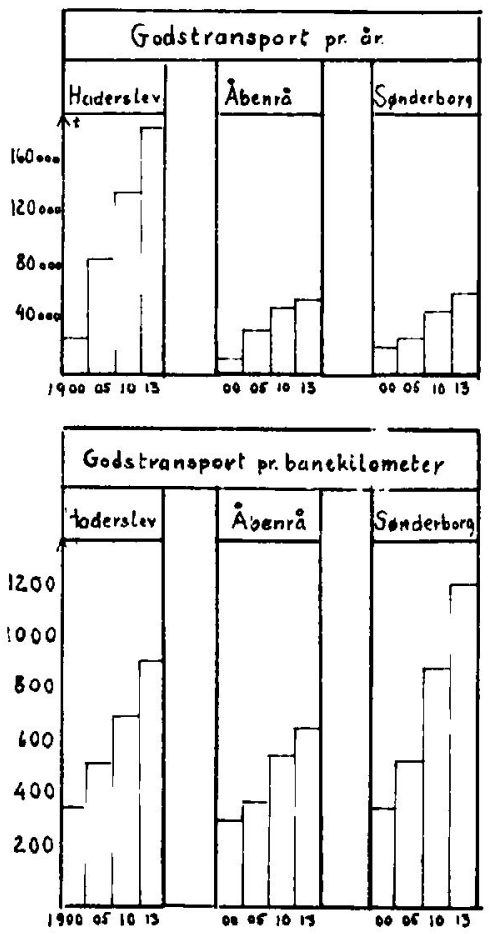

Fig. 6. Smabanernes befordring af passagerer og gods. (Efter Paap).

lige fremgang, som Als-banerne $\mathrm{i}$ så henseende havde $\mathrm{i}$ forhold til de to andre kredses småbaner, stod naturligvis $\mathrm{i}$ forbindelse med, at de egne, som Als-banerne gennemløb, er langt mere frugtbare end det opland, som mange af de andre småbaner havde. Desuden var befolkningstætheden på Als betydelig større end i Ảbenrå og Haderslev kredsene. I 1913 var der nemlig 90 indbyggere pr. km² på Als, medens der i Ảbenrå kreds var 47 og i Haderslev kreds 38 indbyggere pr. $\mathrm{km}^{2}$. Der var da også det karakteristiske ved småbanernes persontrafik pr. $\mathrm{km}$ banekilometer, at medens den i Haderslev kreds faktisk var den samme i hele perioden 1900-1913 og i Åbenrå kreds endog faldende i denne periode, så steg den så stærkt på Als-banerne, at den blev disse baners største indtægtskilde.

Den væsentligste grund til, at der på alle tre kredses småbaner foregik en betydelig stigning af godstransporten $i$ den omhandlede 
periode, må dog søges $\mathrm{i}$ de stærkt opadgående tider, og først og fremmest $i$ den udvikling, der omkring 1890 satte ind $i$ landbruget, hvor de bedrede forhold øgede både forbruget og produktionen. Men også her var Sønderborg kreds bedre stillet, idet landbruget i denne kreds havde gennemgået en gunstigere udvikling end $\mathbf{i}$ de andre kredse, blandt andet på grund af den forståelse, som dette erhverv havde mødt hos kredsens landråd v. Tschirschnitz - i modsætning til, hvad der var tilfældet hos landråd v. Uslar i Ãbenrå og dr. Mauve i Haderslev. ${ }^{108}$

Men som helhed nød landbruget $i$ Nordslesvig godt af de tyske toldforanstaltninger fra $1880^{\prime}$ erne, der gav sig til kende $i$ en betydelig prisstigning på landbrugsprodukterne. Kornarealerne forøgedes, og dette $\mathrm{i}$ forbindelse med det større foldudbytte betød en fremgang $\mathrm{i}$ høstudbyttet. Udtrykt $\mathrm{i}$ foderenheder steg det samlede høstudbytte $\mathbf{i}$ Nordslesvig fra 1900/04 til 1910/14 med over 50\% ${ }^{109}$

Med hensyn til husdyravlen skete der især en afgjort forandring $i$ svineavlen. Der havde længe været en betydelig indforsel af svin fra Danmark til Tyskland, men da der i 1905 havde været nogle tilfælde af en smitsom sygdom blandt svinene i Danmark, lukkede Tyskland helt for denne indforsel. Slesvig-Holsten var nu uden væesentlig konkurrence til så betydelige markeder som Hamborg og industriområderne, ${ }^{110}$ og dette var medvirkende til, at den nordslesvigske svineavl nu udviklede sig med rivende fart. I Sønderborg kreds var der således i 1913172 svin pr. 100 hektar landbrugsjord, d.v.s. dobbelt så mange som gennemsnittet for Danmark. ${ }^{109}$ I Haderslev kreds var svinetallet fra 1873 til 1913 steget fra 7 til 57 pr. 100 hektar landbrugsjord.

De hyppige leverancer af fedesvin betød en væsentlig forøgelse af jernbanernes og i særlig grad af småbanernes transport. I Haderslev steg antallet af svin, som de mange småbaner transporterede til byen, fra 3.742 i 1900 til 19.048 i 1910,111 og det var takket være dette, at Haderslevs grisemarked udviklede sig til at blive det største i SlesvigHolsten. ${ }^{110}$ Men de mange småbaner, der udmundede i Haderslev, var også medvirkende til, at der med den stadigt stigende kreatur- og hestebestand i Haderslev kreds efterhånden blev en ret stor handel med disse husdyr i kredsbyen.

I det hele taget afspejlede den stærke vakst i kreaturholdet sig i den kreaturtransport, der fandt sted på småbanerne. På Ābenrå-Gråsten banen steg antallet af transporterede kreaturer (hornkvæg, svin og 
får) i tiden fra 1899 til 1913 fra 7.100 til 16.000, og på AbenråLøgumkloster banen transporteredes der i 191323.000 kreaturer mod 10.400 i 1901 . Men småbanerne i Haderslev kreds kunne opvise en endnu større stigning i kreaturtransporten. På disse baner transporteredes der i 1899 ialt 10.200 stk. kvæg, men dette tal var i 1913 steget til 69.300.112

Men det øgede kreaturhold var også med til at bane vejen for andelsmejeribevægelsen. Det nordslesvigske mejeribrug, der meget hurtigt tog lære af den imponerende udvikling af mejeribruget i Danmark, opnåede snart en førerstilling $i$ hertugdømmerne, og salget af mejeriprodukterne fremmedes ved det intime samarbejde mellem producent og handlende, som opnåedes ved oprettelsen af smøreksportforeninger.

Det nordslesvigske landbrugs stadigt mere intensive drift gjorde, at småbanerne fik en ikke ringe betydning ved for det første at lette afsætningen af landbrugets voksende produktion og for det andet ved at besørge transporten af den efterhånden store mængde af de nødvendige produktionsmidler og andre forbrugsvarer som f.eks. bygningsartikler samt kul og koks, der bl. a. skulle dække det store brændselsforbrug i mejeriernes dampmaskiner. Således krævede den stigende intensitet indenfor landbruget også større forbrug af foderkager og kunstgødning, hvad også bevirkede, at der meget hurtigt oprettedes korn-, foderstof- og gødningsforretninger i såvel købstæderne som $i$ adskillige stationsbyer.

Hertil kom så, at det kunne ske, at en småbanestrækning for en tid fik betydning for transporten af mergel. For småbanerne i Ảbenrå kreds var det udelukkende banen til Logumkloster, som i en årrække havde en ret stor transport af dette jordforbedringsmiddel. Samtlige vognladninger af mergel udgik fra det sted, som i driftsberetningerne kaldes "Mergelberg «. Det lå mellem Åbenrå og stoppestedet Knappen, men figurerede ellers ikke som stoppested. Transporten af mergel begyndte i 1902, da der blev afsendt 1705 vognladninger mergel fra "Mergelberg«. Driftsberetningen fra dette år giver - hvad der ikke var tilfældet senere - oplysning om, på hvilke stationer og holdepladser mergelen blev læsset af, og det fremgår af denne statistik, at ca. $85 \%$ af mergelen var bestemt til stationer på den kun ca. $12 \mathrm{~km}$ lange strækning mellem Hovslund og Hellevad Mølle. I de følgende år gik mergeltransporten jævnt tilbage, og i 1913/14, som er det sidste 
år, hvor denne transport figurerer i driftsberetningerne, blev der kun afsendt 35 vognladninger fra Mergelberg. ${ }^{112}$

Som det fremgår af den grafiske fremstilling (fig. 6), foregik der på Alsbanerne en udvikling af persontrafikken, der nogenlunde svarer til udviklingen $\mathrm{i}$ godstransporten, idet passagerantallet pr. jernbanekilometer steg med 188\% i tiden 1900-1913 og godstransporten med $214 \%$. Men med hensyn til persontrafikken på småbanerne i Haderslev og Åbenrå kredsene forholdt det sig som nævnt noget anderledes. Medens passagerantallet pr. jernbanekilometer i Haderslev kreds var så at sige uforandret $\mathrm{i}$ den omhandlede periode, var det på småbanerne i Åbenrå kreds stadigt dalende, idet der i 1913/14 kun befordredes 3.269 passagerer pr. jernbanekilometer mod $4.430 \mathrm{i}$ 1900/01. Hertil er dog at bemærke, at det totale passagerantal på linien Ảbenrå-Gråsten steg fra 159.990 i 1901/02 til 160.552 i 1913/14 til trods for, at denne bane gennemløb strækninger, hvor konkurrencen med statsbanerne kunne gøre sig gxldende $\mathrm{i}$ visse områder. Det var således linien Ảbenrå-Løgumkloster, der var årsagen til nedgang i antallet af passagerer på kredsens småbaner, idet det samlede passagerantal på denne linie i perioden 1901/02 til 1913/14 dalede fra 138.509 til 119.899. Dette kom dog ikke som nogen overraskelse. Allerede da småbanen til Løgumkloster blev åbnet, blev det sagt, at denne bane var god nok til Hovslund, men at den videre mod vest ville tabe sin betydning. ${ }^{113}$ Hovslund, der var overgangsstation til statsbanen, blev da også den station på Løgumkloster-banen, der havde den største indtægt. I 1913/14 var den samlede indtxgt her 29.601 mark, medens indtægterne på småbanestationen i Løgumkloster og i Løjt Kirkeby var henholdsvis 11.376 og 3.963 mark.

Småbanernes driftsberetningers oplysninger om den stigende transport af gods og kreaturer samt om den - bortset fra Ábenrå kreds voksende passagerbefordring viser, at disse baner fremkaldte en trafik, som var af en helt anden størrelse end den, der havde været tidligere, og ved at fremkalde denne livligere trafik mellem by og land var der altså opnået det, der var hensigten med anlæggene af småbaner. Befordringen med småbanerne var iøvrigt ikke alene hurtigere, men den var også billigere end tidligere, idet man kunne regne med, at en personkilometer med banen før krigen kostede 3-5 pfg., medens den med postrognen kostede 10-15 pfg. ${ }^{114}$

Men medens det er ret let at få oplysninger om småbanernes drift 
- selv om man kunne ønske, at der flere steder var foretaget en større differentiering inden for de enkelte poster, som f. eks. med hensyn til betegnelsen «Kleinvieh *, der omfatter både svin, får og geder - så er det langt vanskeligere at få tilstrækkelige oplysninger om den virkning, som jernbanerne havde på de erhvervsmæssige og andre forhold i kredsene.

Småbanerne skulle selvfølgelig tjene til at forbedre samfærdselsforholdene; men de blev dog af kredsforvaltningerne i særlig grad betragtet som en foranstaltning, der skulle hæve kredsens almindelige velfærd og derigennem oge befolkningens skatteevne. ${ }^{115}$ I disse udprægede landbrugsområder blev det da en hjælp til at forbedre landbrugsforholdene, som man især tænkte på. Og selv om man fra tysk side ikke lagde skjul på, at udbygningen af småbanerne ikke udelukkende skulle ske af hensyn til kredsens velfærd, men at den måske nok så meget skulle tjene som middel $\mathrm{i}$ en bevidst fortyskningspolitik, så kan man sikkert ikke se bort fra, at disse baner var en økonomisk nedvendighed.

Den omstrendighed, at hver af kredsene havde sit eget småbanesystem, som var uden forbindelse med nabokredsen, viser den vxgt, som man lagde på at gøre forbindelsen mellem kredsbyerne og deres opland så god som muligt for derigennem at gøre, hvad man kunne for at inddrage hele kredsen $\mathrm{i}$ kredsbyens oplandsforhold. At man så sandsynligvis også ved fastlæggelsen af visse småbaners linieføring har haft $\mathrm{i}$ tankerne at prøve på at få nogle af nabokredsens grænseområder inddraget $\mathrm{i}$ den pågxldende banes opland synes f.eks. at fremgå af de tidligere omtalte linier langs hver side af græensen mellem Ảbenrå og Haderslev kredsene.

Da østkystbyerne således havde hver sit småbanesystem, kom jernbanerne her som regel ikke til at betyde de store ændringer $\mathrm{i}$ disse byers oplandsområde, som man har kunnet iagttage andre steder. Men det skete dog, at spørgsmålet om anlægget af en jernbane fremkaldte heftige diskussioner mellem nordslesvigske købstæder, der hver for sig bestræbte sig for at få banen lagt således, at de fik så godt et opland som muligt. Dette var således tilfældet, da man skulle fastlægge linieføringen for banen fra Sønderborg til den østlige længdebane. Det gav anledning til, at Sønderborg, Ảbenrå og Flensborg ihærdigt kæmpede for deres respektive oplandsinteresser. Under de ofte meget bevægede drøftelser, der fra 1880'erne fandt sted om 


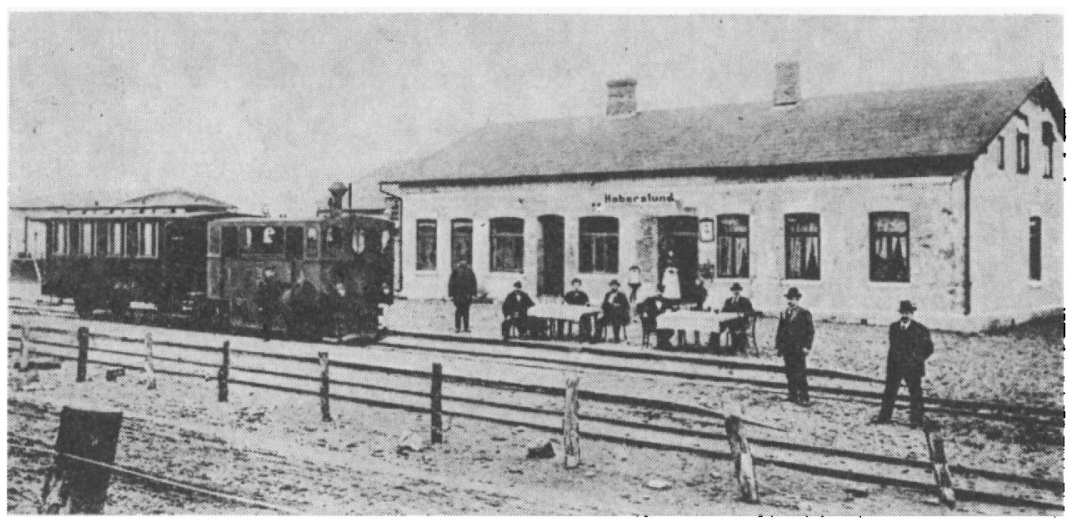

Hovslund station på småbanen Abenrä-Løgumkloster ca. 1902. (Historiske Samlinger for Sønderjylland).

denne bane, blev det af tilhængerne af, at banen skulle gå til Tinglev, hævdet, at ved en sådan bane ville Sønderborgs opland komme til at strække sig helt til egnene omkring Felsted og Kværs. Ved den i 1899 åbnede bane fra Ảbenrå til Gråsten bevaredes dog den nordligste del af disse egnes tilknytning til Ảbenrå; men denne by fik alligevel sit sydlige opland stærkt beskåret ved anlægget af jernbanerne over Tørsbøl til Tinglev og Padborg. Folk fra Kliplev og Bjerndrup - ja, også fra Tørsbøl og Kværs - som tidligere havde handlet i Ábenrå, blev nu draget til Flensborg. At denne by var stærkt interesseret $i$ dette nye virkefelt, ses blandt andet af, at varehuse i Flensborg i disse år indrykkede store annoncer $i$ aviserne med tilbud om fri rejse tur/retur til Flensborg, hvis kunden foretog indkøb for mindst 20 mark. Det skete dog også, at man fra de nævnte egne gjorde indkøb i Sønderborg, således som man havde forudset det i 1889; men til Abenrå tog man kun, når der skulle købes tømmer eller træ. ${ }^{116}$

I øvrigt blev det fra Flensborg ofte betonet, at man fra størstedelen af det gamle Lundtoft herred, der omfattede det meste af halvøen mellem Ảbenrå og Flensborg Fjord helt over til Gråsten, aldrig havde haft forretningsforbindelser med Ảbenrå, men altid havde haft tilbøjelighed til at søge til Flensborg. ${ }^{117}$ Det var også det, der var medvirkende til, at man $\mathrm{i}$ Flensborg arbejdede så kraftigt for, at banen fra Sønderborg skulle føres til Padborg i stedet for til Tinglev. 
Med hensyn til opland var Haderslev langt mere begunstiget end Åbenrå. Byens placering, hvor den lange og smalle fjord skærer sig dybt ind $i$ landet, gør, at den kommer til at ligge som midtpunkt $i$ et stort område, hvis østlige del udmærker sig ved stor frugtbarhed. Den store vestlige del af Haderslevs opland var næsten helt gået tabt for byen på grund af de dårlige forbindelser, der hidtil havde været mellem disse egne og Haderslev; ${ }^{118}$ men anlægget af småbanerne gjorde, at disse egne atter kom ind under Haderslevs handelsområde. At der opstod en betydelig godstrafik på jernbanerne til Toftlund og Arnum fremgår af, at der i 1913 på disse strxkninger måtte indsættes et godstog $\mathrm{i}$ hver retning, for at man kunne klare den stærke godstrafik. ${ }^{119}$

Den udvikling af trafikken, som bygningen af jernbanerne kom til at betyde, medførte her som andre steder adskillige $x$ ndringer $i$ bebyggelsen. Dette gav sig især udslag $i$, at der ved mange af jernbanestationerne groede stationsbyer frem. Men når flere af stationsbyerne $\mathrm{i}$ Nordslesvig $\mathrm{i}$ årenes løb nåede en ganske betydelig størrelse, skyldes det ikke alene deres beliggenhed, hvor jernbanen krydser en mere betydelig vej. Det er som regel en hel række samvirkende forhold, der har gjort sig gældende, således at det bliver vanskeligt at afgrænse den betydning, som jernbanerne har haft.

De vigtigste af disse forhold var som nævnt de stærkt opadgående tider og den udvikling, der foregik i landbruget. Denne udvikling gav sig blandt andet udslag $i$, at selvforsyningen inden for landbruget var stxrkt aftagende. Tidligere tiders »hjemmeindustri« var nu for en stor del udskilt fra landbruget. Man begyndte at handle $\mathrm{i}$ landsbyerne, hvor der nu var gode muligheder for købmænd og håndværkere. Denne ændring af livsformen blev begunstiget af jernbanerne, idet de landsbyer, der lå i nærheden af en jernbanestation, let kunne få varer fra købstaden med jernbanen til stationen, hvorfra der så kun var et kort stykke at transportere dem med hestevogn.

Når landsbyen lå meget nær ved stationen, kunne der ske en sammenvoksning af den bebyggelse, der var vokset op omkring jernbanestationen, og den nærliggende landsby, således at der opstod en langstrakt dobbeltby. Det smukkeste eksempel på en nordslesvigsk stationsby af denne type er vel nok Sommersted, hvor den samlede bebyggelse nu har en langde af ca. $2,5 \mathrm{~km}$. Dette bevirkede, at småbanen, der gik igennem Sommersted i øst-vestlig retning, havde ikke mindre end 4 stationer og holdepladser $\mathrm{i}$ byen, og hertil kom selv- 
følgelig statsbanestationen. Ved stationsbyen Tinglev er der ligeledes sket en sammenvoksning af den oprindelige landsby, der la ca. $1 \mathrm{~km}$ vest for jernbanen, og den bebyggelse, der opstod omkring jernbanestationen. Desuden hører også Padborg med til denne type af stationsbyer. Ved folketzllingen i 1921 var der her kun 47 indbyggere, ${ }^{120}$ men da denne lille bebyggelse nu var blevet grænsestation, kom den ind $i$ en sådan udvikling, at den efterhånden voksede sammen med de gamle landsbyer Frøslev og Bov til en bymæssig bebyggelse, der $\mathrm{i}$ 1960 havde ca. 3.000 indbyggere.

Undertiden udviklede stationsbyen sig af en landsby, der lå lige ved banelinien, som f. eks. Skærbæk og Døstrup; men det kunne også ske, at stationsbyen opstod på et sted, hvor der overhovedet ikke havde været nogen bebyggelse.

Det mest typiske eksempel på en stationsby af denne type er Vojens. Før længdebanen blev bygget, henlå egnen her for en stor del som ret øde hede- og mosestrækninger, hvor der kun lå nogle enkelte gårde og et par små huse. Ved diskussionen om, hvilken retning den kommende længdebane skulle have, blev der for en eventuel station her anvendt betegnelsen Vojensgård; men ved regulativet af 1. maj 1862 bestemtes det, at der skulle placeres en jernbanestation "Vojem ved stambanens krydsning med Ribe-Haderslev mindre landevej «. Stationen fik imidlertid navnet Vojens efter en i 1500-tallet nedlagt landsby, som lå på den nærliggende Vojensgårds marker.

I gadenettet i Vojens kan man altså ikke, som det ellers så ofte er tilfældet i stationsbyerne, finde mindelser om en tidligere landsbybebyggelse. Det regelmæssige system af gader, der for sterstedelen skærer hinanden under rette vinkler, viser tydeligt, at der her er tale om en nyanlagt by.

I Haderslev nærede man en vis frygt for, at der ved en jernbanestation ved Vojens ville opstå en handelsplads, som ville kunne blive til skade for Haderslev. Men i 1862 udtalte Laurids Skau som sin mening, at "på den golde hede opstår aldrig en betydelig handelsplads, da jernbanetransporten er alt for kostbar, og transporten gennem en lidet befolket og ufrugtbar egn til stationen er for lang “. ${ }^{121}$

Det skulle dog komme til at gå helt anderledes, idet der ret hurtigt opstod en lille bebyggelse omkring den nye station. Man fandt det hensigtsmæssigt, at der her oprettedes handelsvirksomheder for såvel de daglige fornødenheder som for det nødvendige til landbrugets drift 
og for afsætningen af landbrugsprodukterne. I 1868 - kun to år efter, at jernbanen fra Flensborg var ført frem til Vamdrup - startedes der i Vojens en Sønderjysk Smøreksportforening, og tre år senere blev her grundlagt Jul. Nielsens Korn-, Foderstof- og Tømmerforretning.

Ābningen af småbanen Vojens-Gram-Rødding i 1899 gav yderligere stødet til en fornyet vækst af byen. I 1901 grundlagde Hans Gram fra Farris Maskinfabrik for Mejeribrug, Landbrug og Industri i Vojens. Han havde øjnene åbne for, at »her i midtpunktet og knudepunktet for amtsbanerne i hele Haderslev kreds måtte det være muligt at betjene et større opland. Vojens var jo et godt udfaldssted for den, der vil betjene kreds Haderslevs mejerier og andre virksomheder, som havde brug for hjælp fra en mekanisk installationsforretning «. ${ }^{122}$ I 1907 begyndte samarbejdet med broderen Aage Gram, og efter genforeningen opgav man den fabrikation af mejerimaskiner og -vægte, som man havde ført frem med stort held, og omdannede virksomheden til den specialfabrik for køle- og frysemaskiner, som nu er en af Danmarks største af den art.

Efter genforeningen og da især efter anden verdenskrig kom denne stationsby ind $\mathrm{i}$ en periode med meget stærk udvikling, således at dens indbyggertal, der i 1921 var 792, i 1976 var steget til 6.249.

Vojens er således et meget slående eksempel på, hvorledes en stationsby kan komme ind $i$ en rivende udvikling, når vækstbetingelserne er særlig gode.

Det kunne dog også ske, at en jernbane bevirkede, at et bysamfund, som lå nær ved en købstad, stagnerede eller endog gik tilbage. Dette var således tilfældet med Christiansfeld. Denne flække, der i 1864 havde ca. 680 indbyggere, og som ved grænsedragningen $i$ dette år mistede en væsentlig del af sit opland, formåede ikke at tage konkurrencen op med Haderslev, og den i 1899 åbnede bane mellem de to byer gavnede heller ikke Christiansfeld. En tilbagegang satte ind, og befolkningstallet dalede til under 600 .

Noget lignende gjorde sig galdende for Broagers vedkommende. Den i 1910 åbnede statsbane fra Vester Sottrup over Broager til Skelde kom nærmest til at skade Broager, idet indbyggerne her nu, da der var kommet en lettere forbindelse til Sønderborg, begyndte at gøre deres større indkøb i denne by. Og på samme måde gik det Nordborg. Da Als-banen blev bygget, viste det sig, at Sønderborg havde større tiltrækningskraft på Nordborgs opland, og denne bys ind- 
byggertal, der i 1900 havde været 1139, var ved genforeningen dalet til 1035.

Iøvrigt havde Flensborg måttet opleve noget lignende. For det forste havde anlægget af den sydslesvigske jernbane bevirket, at byens handelsmæssige opland blev væsentligt indskrænket, og i 1880'erne imødeså man i Flensborg med en ikke ringe ængstelse den uheldige indflydelse, som man frygtede, at den planlagte vestlige længdebane ville kunne få for byens handel med de frugtbare marskområder. Desuden mente man, at denne kommende "marskbane" ville kunne påføre Flensborg en vis konkurrence ved at skaffe de vestslesvigske egne en bedre forbindelse med de ovrige egne af provinsen. For at imødegå denne banes skadelige virkninger satte Handelskammeret i Flensborg derfor al kraft ind på at få etableret den bedre forbindelse med Vestslesvig - en jernbane fra Flensborg til Læk og Nibøl - som man havde ønsket $i$ længere tid, og i 1889 var denne bane så færdig-

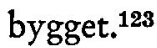

Når man ser på, hvorledes befolkningsudviklingen var i de fire nordslesvigske købstæder i tiden fra 1840 til 1910, viser det sig, at det for dem alle gxlder, at der efter en mere jævn udvikling indtil tiden omkring år 1900 kommer en mærkbar stigning $i$ årene 1900-1910. Denne stigning var størst i Haderslev og Sønderborg. Ganske vist må det tages $\mathrm{i}$ betragtning, at tilvæksten i Sønderborgs indbyggertal i disse år for en stor del skyldtes, at der $i$ årene 1904-07 byggedes en marinestation i denne by. Dette bevirkede, at den militære belægning i Sønderborg næsten firedobledes, således at den i 1910 androg næsten 2000 mand, hvilket svarede til en fjerdedel af byens civile indbyggertal. ${ }^{124}$

Fremgangen $\mathrm{i}$ købstæderne var nøje forbundet med den almindelige økonomiske opgang og udviklingen i landbruget. Og her kommer naturligvis småbanerne $\mathrm{i}$ høj grad med ind $\mathrm{i}$ billedet.

For Sønderborgs vedkommende var det især Als-banerne, der kom til at få betydning, da det var Als, der var den vasentligste del af denne bys opland. For det første udgjorde denne frugtbare $\varnothing$ ca. $71 \%$ af Sonderborg kreds, og den ret store befolkning her var i overvejende grad henvist til at søge forbindelse med Sønderborg. Persontrafikken på Als-banerne viser tydeligt, hvorledes alsingerne allerede fra banens start $i$ stadig stigende grad benyttede denne lettere forbindelse til øens største by. Det er således værd at lægge mærke til, at 
man allerede 4 år efter disse baners åbning kunne foretage en nedsættelse på 35-40 \% af billetpriserne. ${ }^{125}$ Medens der i 1901 blev befordret 159.000 passagerer på Als-banerne, var dette tal i 1910 steget til 543.000 .

Også godstransporten viste en betydelig stigning, idet indtægten ved godstransporten i 1913 var over 3 gange så stor som i 1900 . Med hensyn til transporten af gods må det dog bemærkes, at her spillede også kystsejladsen, som tidligere nævnt, en vis rolle. Betingelserne for transport ad denne vej var jo her særdeles gode, idet der på Als ikke er et sted, der har mere end $5 \mathrm{~km}$ til havet. På den $164 \mathrm{~km}$ lange kystlinie - d.v.s. at der er $1 \mathrm{~km}$ kyst pr. $1.9 \mathrm{~km}^{2}$ landareal - var der adskillige steder, hvor småskibene kunne sejle ind for at losse deres last af almindeligt forekommende forbrugsvarer som kolonialvarer, foderstoffer, brændsel, byggemateriale $m$. v. for derefter at indtage en last af landbrugsprodukter, som fortrinsvis førtes til Sønderborg. Men over enkelte af havnestederne foregik der også en udførsel af korn og frugt. På Als' østkyst var der især i slutningen af 1800-tallet en ret stor udførsel af landbrugsprodukter. Dette var også tilfældet med Augustenborg. For egnen omkring Nordborg havde den lille havn ved Dyvig til tider spillet en ret betydelig rolle, bl. a. som udførselssted for korn til bl. a. Holsten; men anlægget af banen til Nordborg skadede dog denne lille havn en hel del.

I ovrigt havde der længe været en forbindelse mellem Als Nørreherred og Ảbenrå, hvorfra der f. eks. kom tømmer. Denne forbindelses betydning viste sig, som nævnt i Sønderjyske Årbøger 1975, bl. a. ved, at Als Nørreherred under diskussionen i 1861 om en længdebane, ønskede en jernbaneforbindelse fra Ảbenrå over Rødekro til Tønder, medens Sønderborg og det sydlige Als var stemt for, at Tinglev skulle være udgangspunktet for banen til Tonder.

Forbindelsen mellem det nordlige Als og Abenrå, som naturligvis måtte gribe noget ind i Sønderborgs oplandsinteresser, blev styrket, da Flensborg-Egernsund-Sønderborg Dampskibsselskab etablerede faste ruter 4 gange daglig mellem Sønderborg-Nord-Als og Åbenrå.

Forbindelsen mellem Sønderborg og dens opland i Sundeved blev delvis besørget af statsbanerne. I den vestlige del af kredsen begyndte Gråstens indflydelse efterhånden at gøre sig gxldende. Dette var især tilfældet, efter at den nye landevej mellem Sønderborg og Kruså var blevet anlagt i 1856-57. Den mere intime kontakt med oplandet, som 
var skabt herved, var medvirkende til en opblomstring af Gråsten, ${ }^{126}$ og i samme retning kom småbanen til Ảbenrå til at virke. Også åbningen af statsbanen i 1901 betød, at Gråsten tog en del landkunder fra Sønderborg. ${ }^{127}$

Også på Tinglev-banen var trafikken i stor stigning. Medens der i 1902/03 solgtes 45.000 billetter på Sønderborg station, var dette tal i 1910/11 steget til 112.000, og $\mathrm{i}$ de følgende par år var stigningen så stærk, at der i 1913/14 blev solgt 168.000 billetter her. Også godstransporten udviklede sig stærkt. På Sønderborg godsekspedition steg indtægten i tidsrummet 1902/03-10/11 fra 143.000 mark til 428.000 mark. ${ }^{128}$

Det kunne snart mærkes i Sønderborgs erhvervsliv, at jernbanerne var kommet igang, og de ovenfor anførte tal kan da også være med til at illustrere den udvikling, der fandt sted $\mathrm{i}$ byens forretningsliv. Det livligere samkvem med landbefolkningen, som nu var blevet mere købedygtig, gav sig udslag $\mathrm{i}$, at der $\mathrm{i}$ årene 1905-10 i Sønderborg blev startet såvel korn- og foderstofforretninger som smøreksport-forening og xgeksport.

I byerne Haderslev og Åbenrå fandt der en lignende udvikling sted. For Haderslevs vedkommende var det naturligvis af stor betydning, at småbanerne på en næsten ideel måde strålede ud fra byen til faktisk alle hjørner af den store kreds. Med den i 1910 åbnede småbaneforbindelse over Gram og Toftlund til Skærbæk nåede Haderslevs bagland faktisk helt over til vestkystegnene. Åbningen af denne banestrækning medførte dog ikke nogen særlig stor stigning i mængden af ankommet og afsendt gods på Haderslev småbanegård, men hvad denne bane kom til at betyde ses af, at småbanens trafik på Skærbæk station $\mathrm{i}$ løbet af de 3 år, før verdenskrigen begyndte, voksede så stærkt, at småbanestationen her i 1913/14 kun stod tilbage for Haderslev og Over Jerstal.

Statsbaneanlæggene og det udstrakte småbanenet var medvirkende til, at forretningslivet i Haderslev fik en betydelig opgang. Allerede i 1875 var der her blevet grundlagt Outzens Korn-, Foderstof- og Kunstgødningsforretning; men denne forretning oprettede senere filialer $\mathrm{i}$ Christiansfeld og Toftlund, ${ }^{129}$ og $\mathrm{i}$ årene lige efter 1900 oprettedes endnu nogle korn- og foderstofforretninger samt en trælastforretning $i$ byen.

Småbanernes betydning for Haderslev kan fremgå af den stigning, 


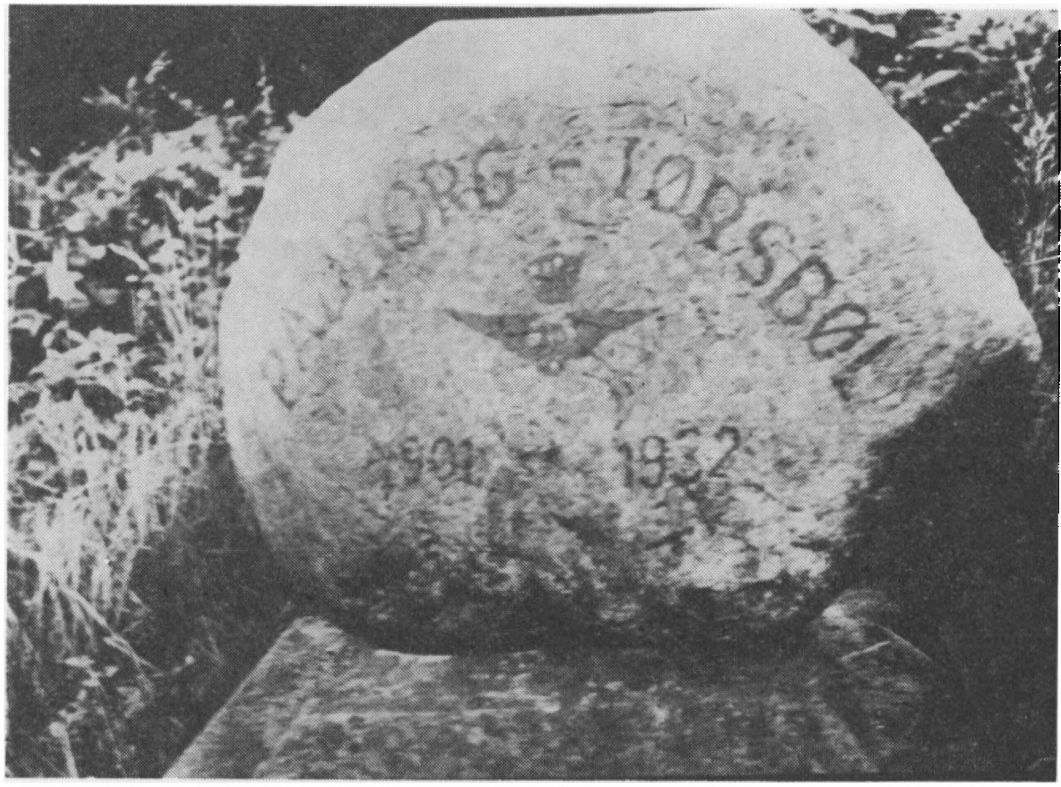

Mindesten ved Torsbol station for den nedlagte Padborg-Torsbal jernbane.

(Foto: N. H. Jacobsen).

som amtsbanegården $i$ denne by kan notere i mængden af afsendt og ankommet gods. I 1900/01 afsendtes der herfra 8.384 tons ilgods, stykgods og vognladningsgods, medens der ankom 3.872 tons, men i 1913/14 var disse tal henholdsvis 65.920 og 20.187 tons. At småbanerne blev flittigt benyttet af kredsens befolkning ses af, at der $i$ 1913/14 solgtes ialt 985.358 billetter på kredsens småbanestationer og heraf alene i Haderslev 248.058. 130

Småbanernes trafik på Ảbenrå udviklede sig ikke helt på samme måde som i Haderslev. Medens der i 1901/02, da udbygningen af småbanerne i Åbenrå kreds var afsluttet, fra Ảbenrå blev afsendt 7.118 tons gods med småbanerne, og dette tal $\mathrm{i}$ årene 1910-14 var steget til ca. 20.000 tons, forholdt det sig anderledes med det antal passagerer, som rejste med småbanerne fra Ảbenrå. I 1901 blev der i Åbenrå solgt 81.808 billetter til disse tog; men dette antal var i 1913 dalet til 77.180 .

Alligevel blev disse baner af betydning for Ảbenrå. Forretnings- 
livet $\mathrm{i}$ denne by havde i $1890^{\prime}$ erne været inde i den stilstandsperiode. Den 19. juli 1895 skrev Hejmdal: "Åbenrå hører til de byer, der ikke har forstået de nye tiders krav, og dens næringsliv er derfor stærkt sygnende«. »Borgernes ulyksalige angst for ethvert nyt foretagende rider byen som en mare. Derfor har vi også en jernbanekommission, der ikke har givet livstegn fra sig i flere år«. Og bladet fortsætter med en beskrivelse af, hvorledes Åbenrås før så blomstrende velstand er fortæret, medens landbruget er inde i en stærk udvikling. Selv en så forholdsvis lille, men naturligvis meget vigtig sag som anlægget af en havnebane mødte megen modstand. Men omkring 1900 fik byen dog et vist opsving, som for en del stod i forbindelse med den væsentlige lettelse af oplandstrafikken p. gr. af småbanerne. ${ }^{131}$ Noget egentlig småbanenet som i Haderslev kreds kunne man ganske vist ikke tale om her, da de to småbaner i Åbenrå kreds gik næsten diametralt modsat ud fra byen. Og dette, at disse to baner - og da især Løgumkloster-banen - på større eller mindre strækninger løb i nærheden af grænsen til nabokredsene, kunne måske gøre nabokredsenes mulighed for konkurrence større.

Men trods alt betød det, at man havde fået det moderne samfærdselsmiddel, at Åbenrå blev en oplandsby af en vis betydning. Trafikken på byens havn steg da også ganske stærkt, og at dette for en stor del skyldtes småbanerne, fremgår af, at denne trafikstigning især satte ind, efter at småbanerne var blevet bygget. I 1895 ankom der til Ảbenrå 316 skibe med et samlet rumindhold på $68.500 \mathrm{~m}^{3}$. Disse tal var i 1900 steget til 434 skibe på ialt $89.431 \mathrm{~m}^{3}$, og i de følgende 5 år voksede trafikken på Åbenrå havn så betydeligt, at der i 1905 ankom 875 skibe på ialt $142.000 \mathrm{~m}^{3} .^{132}$ I årene op til verdenskrigen var byen da også i almindelig fremgang. Der flyttede mange unge forretningsfolk til Åbenrå, hvor de oparbejdede betydelige virksomheder. Der blev således flere store korn- og foderstofforretninger. Iøvrigt var der allerede da et par større trælastforretninger i Åbenrå, som på den tid var den by i provinsen Slesvig-Holsten, der havde den største import af tømmer fra Sverige og Finland. ${ }^{133}$ Ảbenrå var da også den af de nordslesvigske havnebyer, hvorfra der med jernbanen videresendtes langt den største mængde af tømmer. I 1913 afsendtes der således 7.724 tons tømmer med statsbanen fra Åbenrå, medens der fra Gråsten blev afsendt 839 tons, fra Haderslev 438 tons og fra Sønderborg 203 tons. ${ }^{134}$ 
En anden særstilling kom Åbenrå rent trafikalt til at indtage ved, at der i 1895 her blev oprettet en karantænestation, hvor det danske malkekvæg, der var indført ad søvejen, skulle underkastes en længere karantæne, før det sendtes videre ned i Tyskland. Denne indførsel af kvæg, der i 1901 kun var på 5.000 stk., var i 1910 oppe på 56.271 stk. ${ }^{135}$ Dette gav anledning til, at der afholdtes store kvægmarkeder og til, at der ofte afsendtes lange jernbanetog med kreaturer til Ruhr-området. ${ }^{136}$

I modsætning til, hvad der var tilfældet i de andre kredse, var det ikke lykkedes Tønder kreds at få anlagt småbaner, selvom der i årenes løb havde været fremsat forskellige planer derom. Igennem en meget lang årrække havde Tønder måttet kæmpe for at bevare sit opland og for at få en bedre forbindelse med de andre egne af landsdelen. I den danske jernbanetids allerforste år havde man således været interesseret i at få en jernbane fra Højer over Tønder til Åbenrå eller Flensborg. Det var altså forbindelsen med østkysten, man især var interesseret $i$, sådan som man havde været det igennem de århundreder, hvor vadehavskysten havde spillet en ikke ubetydelig rolle som importområde. ${ }^{137}$ Helt op til midten af 1800-tallet havde Tønder således fået en meget stor del af sine forsyninger fra havnen ved Højer, hvorover der også var en livlig transit af f. eks. hamborgske varer til østkystbyerne.

Men ved åbningen af jernbanen fra Tinglev til Tønder blev dette forhold nærmest vendt helt om, idet det nu blev havnene ved ostkysten, der kom til at stå som hovedindførselssteder for varerne til Tønder. ${ }^{138}$ De mest betydningsfulde havne i så henseende blev Åbenrå og senere hen også Gråsten, hvorfra Tønder f. eks. modtog størsteparten af tømmer og brændsel.

Det var således udelukkende statsbaner, der besørgede trafikken til og fra Tønder. Ved sin beliggenhed, hvor den vestlige længdebane møder banerne fra Tinglev og Højer, blev Tønder et jernbaneknudepunkt og dermed den af de nordslesvigske købstæder, der havde de bedste jernbaneforbindelser til andre egne af Nordslesvig. Som følge deraf blev Tønder da også den nordslesvigske by, hvor der blev solgt flest billetter til statsbanerne, således som det ses af nedenstående skema. Tallene til dette skema er for 1913/14 taget fra den tyske og for 1920/21 fra den danske driftsberetning. ${ }^{139}$ Denne sidste er taget med, da den i modsætning til den tyske statistik foruden antallet af 
solgte billetter også giver oplysning om, hvor stor indtægten ved dette billetsalg var.

Billetsalget til statsbanerne:

\begin{tabular}{|c|c|c|c|}
\hline & \multirow{2}{*}{$\frac{1 / 4 \quad 1913-31 / 3 \quad 1914}{\text { Antal }}$} & \multicolumn{2}{|c|}{$1 / 4 \quad 1920-31 / 3 \quad 1921$} \\
\hline & & Antal & Indtægt \\
\hline $\begin{array}{l}\text { Tønder } \\
\text { Sønderborg } \\
\text { Haderslev } \\
\text { Åbenrå }\end{array}$ & $\begin{array}{l}222.713 \\
167.763 \\
139.884 \\
112.043\end{array}$ & $\begin{array}{r}129.254 \\
62.935 \\
90.177 \\
75.621\end{array}$ & $\begin{array}{l}234.637 \mathrm{kr} \text {. } \\
220.195 \mathrm{kr} \text {. } \\
286.016 \mathrm{kr} \text {. } \\
224.814 \mathrm{kr} \text {. }\end{array}$ \\
\hline
\end{tabular}

Det ses således, at selvom antallet af solgte statsbanebilletter absolut var størst i Tønder, så var indtægten ved salget af billetter her af samme størrelse som $\mathrm{i}$ de andre byer, hvilket betyder, at de rejser, der blev foretaget fra Tønder, gennemsnitlig var af kortere udstrækning og altså i høj grad oplandsrejser.

For Tønder blev jernbanens indflydelse meget gennemgribende, men på en noget anden måde end for østkystbyerne. Den i 1867 åbnede bane til Tinglev betød bl. a., at der nu var etableret en mere bekvem forbindelse med Flensborg, og dette bevirkede, at den hurtigt voksende, store østkystby nu skabte sig en væsentlig indflydelse $\mathrm{i}$ Tønder. Dette gav sig udslag $i$, at mange forretninger i Tønder blev agenturer for og filialer af de store grossist-forretninger og handelshuse i Flensborg, og denne udvikling kom i nogen grad til at svække den tønderske handelsstand. ${ }^{140} \mathrm{~Pa}$ den anden side kom Tønder til at gøre $\sin$ indflydelse gældende indtil Tinglev. ${ }^{141}$

\section{Afslutning}

Den udvikling, som de nordslesvigske jernbaner har gennemgået, har i høj grad været påvirket af landsdelens geografiske og politiske forhold. De geografiske faktorer, der har spillet en stor rolle her, har for det første været den samfærdselsgeografiske beliggenhed. Den omstændighed, at Slesvig og Holsten ligger mellem Nordsøen og Østersøen, gav anledning til, at Den kgl. Jernbanekommission af 1835 udelukkende skulle beskæftige sig med spørgsmålet om anlæg af jernbaner, der forbandt disse to have, medens der senere førtes livlige 
debatter, som også var bestemt af politiske synspunkter, om hvorvidt der skulle anlægges en længde- eller en tværbane. Men dernæst kom de terrænmæssige forhold i Nordslesvig - med morænebakkelandet mod øst, smeltevandsfladerne i midten af landet og marskområderne mod vest - til at blive bestemmende for hovedliniernes forløb.

De politiske forhold her i grænseområdet førte ganske naturligt med sig, at der under drøftelserne om jernbaneanlxggene ofte blev lagt vægt på nationale synspunkter. Dette skete f. eks. fra dansk side, da Klee og Poulsen som et af hovedsynspunkterne for deres i 1850 fremsatte forslag til et dansk jernbanesystem fremhrvede, at det gxlder om at "styrke foreningen af Danmark og Slesvig så meget som muligt ${ }_{0}{ }^{142}$ Men da Nordslesvig blev en del af Preussen, var det naturligvis andre interesser, der gjorde sig gxldende. Det, som bestræbelserne nu gik ud på, var at forbedre forbindelsen med de sydligere egne, hvad der ret omgående efter 1864 viste sig ved den omlægning af Flensborg-Husum banen, der fandt sted i 1870. Dette blev også stærkt fremhævet, da man arbejdede for at få bygget den såkaldte østkystbane; men den betydning, som man mente, at jernbaneanlæg ville kunne få som et middel til at styrke tyskheden i Nordslesvig, blev i øvrigt fremhævet gang på gang. Dette var således tilfældet, da man i 1889 fremsatte planen om en jernbane fra en vestkysthavn til Haderslev og Årøsund, og det var det ikke mindst, da spørgsmålet om småbaner kom på tale. Fra dansk side var man derfor mange steder - selv om man var klar over, at småbanerne i mange henseender ville være til gavn - imod bygningen af dem, fordi man ikke ønskede en forøgelse af den $i$ forvejen ret talrige embedsmands- og bestillingsklasse, som småbanerne ville medføre.

Det store småbanenet i Haderslev kreds kunne selvfølgelig opvise det største antal ansatte, nemlig 432 i 1913/14. Ved småbanerne i Åbenrå kreds var der i samme år ansat 100 og ved Als-banerne 99. De ansatte ved småbanerne bragte nok tyskheden en ny tilvakst og bidrog til en stigning af det tyske stemmetal. Men det er dog vanskeligt at drage slutninger angående det nationale sindelag ud fra valgresultaterne, da småbanernes personale kunne være udsat for pres ved stemmeafgivningen til et valg. Dette var således tilfxldet i Øster Løgum sogn. Her stemte alle tjenestemænd tysk i 1903, 1908 og 1912. Også de dansksindede stemte tysk; men hertil må bemærkes, at de var udsat for trusler om ellers at blive forflyttet til Holsten. ${ }^{148}$ 
I de danske jernbaners historie indtager den udvikling, som jernbanerne i Nordslesvig gennemgik indtil 1920, en særstilling. Det er i disse to artikler blevet forsøgt at redegøre for nogle af trækkene $i$ bl. a. de drøftelser, der gik forud for anlæggene af disse baner og for visse sider af den betydning, de har haft; men forhåbentlig vil studiet af dette emne, som på så mange måder er med til at belyse ganske vigtige sider af Nordslesvigs historie, blive fortsat og uddybet.

\section{Utrykte kilder}

Landsarkivet for de sønderjyske landsdele, Abenrå:

Haderslev landrådsarkiv: Fag 164, 2. 1892-93. Eine Tertiärbahn durch die Kreise Flensburg, Apenrade und Hadersleben von Flensburg bis zur Landesgrenze.

Toftlund herredsfogederi: 9. 1889. Bygning af en jernbane Rømø-SkærbækToftlund-Vojens.

Sønderborg byarkiv: XXIX. 245. 1873-89. Sager vedr. jernbanen Sønderborg-Tinglev. (Heri: A. P. Petersen: Oplysende Beretning over det projekterede Baneanlæg Tingleff-Sønderborg; og I. Jensen og Kuhrt: Die Anlage einer Spurbahn auf Alsen).

Ảbenrå amtsbaners arkiv: 518-20. 1890-1920. Anlægget af banen Sønderborg-Tørsbøl-Tinglev og Tørsbøl-Padborg.

Sønderborg amtsbaners arkiv: 212-217. 1894-1917. Pontonbroen og banestrækninger på fastlandet.

Haderslev bybistoriske arkiv:

Haderslev rådstuearkiv afd. IX, Acta 9, nr. 1b. 1860-1913. Statsbaneanlæg.

Haderslev Handelsstandsforenings arkiv:

1844-1920. Haderslev Handelsforenings forhandlingsprotokol.

Trykte kilder og litteratur

Aviser: Berlingske Tidende

Dannevirke

Dybbøl-Posten

Folkebladet (Haderslev)

Hejmdal

Sonderburger Zeitung

Karl Alnor: Handbuch zur schleswigschen Frage III, 2. Neumünster 1931. Amtsblatt der königlichen Regierung zu Schleswig.

Bericht über die Verwaltung und den Stand der Kreis-Kommunalangelegenheiten des Kreises Sonderburg 1899-1913.

Betenkning afgiven af Den sønderjydske Jernbanekommission. 1923.

Brødrene Gram A/S 1901-51. Vojens 1951. 
Olav Christensen: Blade af Haderslev bys historie fra omkring århundredskiftet. Haderslev 1952.

Olav Christensen: Haderslev Handelsstands-Forening 1844-1969.

Haderslev 1969.

H. V. Clausen: Sønderjylland. 1922.

Svend Dabl og Axel Linvald (red.): Sønderjylland I-II. 1919.

De danske Statsbaner 1847-1947. 1947. D.S.B.

De danske Statsbaner. Beretning om driften 1. 4. 1920-31.3. 1921. D.S.B. Beretning.

E. Dreesen: Die Secundärbahnen mit spezieller Berücksichtigung einer Bahnnetzes für die Provinz Schleswig-Holstein. Meldorf 1878.

Claus Eskildsen: Tønder 1243-1943. Tønder 1945.

M. Favrboldt: Haderslev Latinskoles Historie. Haderslev 1967.

Troels Fink: Aabenraa gennem de sidste 50 Aar. Hejmdal 1. okt. 1943.

Flensborg Bys Historie bd. 2. 1955.

Flensburg. Gescbicbte einer Grenzstadt. Flensborg 1966.

Geschäfts-Bericht der Direktion der Kleinbahn des Kreises Apenrade für die Zeit vom 1. April 1899 bis 31. März 1914. Abenra.

Gescbäfts-Bericht der Direktion der Kleinbahnen des Kreises Hadersleben. H. V. Gregersen: Laurids Skaus brevveksling med politiske venner i Sønderjylland I-II. 1970.

W. Grimm: Die Eisenbahnverhandlungen im Kreise Sonderburg. Ca. 1892. Hans Hansen (red.): Den nordslesvigske Landboforening gennem hundrede Aar. Haderslev 1946.

H. P. Hansen: Amtsbanerne på Als. Fra Als og Sundeved 53, 1975.

H. P. Hanssen: Fra Kampaarene I. 1927.

O. Hedrich: Die Entwicklung der schleswig-holsteinischen Eisenbahnwesens. Kiel 1915.

H. Hejselbjerg Paulsen: Fra de nationale valgs tid i Sønderjylland. SJy Årb 1959.

Peter Kr. Iversen: Højer Flække. Danmark før og nu III, 1954.

N. H. Jacobsen: Skibsfarten i det danske Vadehav. 1937.

Jabresbericht der Handelskammer zu Flensburg 1875-1888.

K. Jansen: Poleographie der Cimbrischen Halbinsel. Stuttgart 1886.

M. Kamphövener: Hundrede Aar. Aabenraa Handelsstand. Åbenrå 1947. Anker Kirkeby og Erik H. Schack: Sønderjylland som det er. 1920.

Fr. Klee og C. M. Poulsen: Motiveret Forslag til en successiv Fuldførelse af et Jernbane-, Dampskibs- og Telegraphsystem for Danmark og Slesvig. 1850.

P. Langhans: Die Seehafen-Projekte an der schleswigschen Westküste. Petermanns geographische Mitteilungen 36, 1890.

Kai Edv. Larsen: Den alsiske Landboforening 1855-1955. Sønderborg 1955.

M. Mackeprang: Nordslesvig 1864-1909. 1910.

M. Mackeprang: Tønder gennem Tiderne. Tønder 1943.

N. Neergaard: Under Junigrundloven bd. 2. 1916. 
P. Paap: Die Kleinbahnen. Schleswig-Holsteinisches Jahrbuch 1920.

Claus Rolfs: Geschichte des Kirchspiels und Fleckens Hoyer. Kiel 1926.

Schleswig-Holsteinische Jahrbücher 2. bd. 1885.

Schmidt: Strassen und Wege. Schleswig-Holsteinisches Jahrbuch 1920.

Sonderborg Bys Historie bd. 2. Sønderborg 1966.

Sønderjyllands Historie V, u. år.

J. P. Trap: Danmark. 5. udg. X. 1965-67.

J. P. Trap: Kongeriget Danmark. 4. udg. IX. 1930.

E. Trümpener: Dänische und deutsche Eisenbahnpolitik. Schleswig-Holsteinisches Jahrbuch 1920.

v. Tschirschnitz: Die Alsener Kreisbahnen. Bericht der Kreis-KleinbahnKommission des Kreises Sonderburg. Sønderborg 1902.

Verkebrsstatistik des Eisenbahndirektionsbezirks Altona 1913.

B. Wilcke: Haderslev amts jernbaner I-II. 1970.

Abenrå Bys Historie bd. 3. Redigeret af Johan Hvidtfeldt og Peter Kr. Iversen. Ảbenrå 1974.

Aage Aagesen: Nordslesvigs befolkningsgeografi. Geografisk Tidsskrift 57, 1958.

Kursiv angiver forkortelser $i$ henvisninger.

\section{HENVISNINGER}

1. Neergaard: Under Junigrundloven s. 1525.

2. Eskildsen s. 57.

3. Dannevirke 14. juli 1879.

4. Ibid. 31. okt. 1879.

5. Rolfs s. 398.

6. Eskildsen s. 57.

7. Dannevirke 20. okt. 1889.

8. Rolfs s. 399.

9. Iversen s. 382 .

10. Langhans s. 119.

11. Ibid. s. 122. Endvidere Folkebladet 10./11. jan. og 4. og 23. nov. 1889.

12. Dannevirke 6. og 27. feb. 1889.

13. Toftlund herredsfogederi 9.

14. Favrholdt s. 241.

15. Berl Tid 3. juni 1844.

16. Sønderborg byarkiv 245 .

17. Sonderburger Zeitung 31. jan. 1882.

18. Sønderborg byarkiv 245 .

19. Sonderburger Zeitung 10. maj 1873.

20. Flensburg. Geschichte einer Grenzstadt, s. 610, note 246.

21. Ibid. s. 363.

22. Jahresbericht 1875.

23. Grimm s. 7.

24. Sønderborg Bys Hist II s. 66. 
25. Dannevirke 9. og 10. juni 1891.

26. Jahresbericht 1885 .

27. Sønderborg byarkiv 245 .

28. Sonderburger Zeitung 28. dec. 1885.

29. Dannevirke 16. april 1889.

30. Jahresbericht 1888.

31. Grimm s. 12.

32. Ibid. s. 13.

33. Grimm s. $14 f$.

34. Dannevirke 3. og 7. april 1889.

35. Ibid. 8. nov. 1889.

36. Ibid. 7. april 1889.

37. Grimm s. 15.

38. Ibid. s. 17.

39. Dannevirke 17. feb. 1891.

40. Grimm s. 4.

41. Dannevirke 1. juni 1891.

42. Ibid. 17. dec. 1891.

43. Ảbenrå amtsbaners arkiv 518.

44. Tschirschnitz s. 5.

45. Bericht 1901-02.

46. Sonderborg amtsbaners arkiv 214.

47. Haderslev Handelsforenings forhandlingsprotokol.

48. Olav Christensen 1969 s. 32.

49. Hedrich s. 188.

50. Trümpener s. 150 f.

51. D.S.B. s. 238.

52. Amtsblatt 1911, s. 307.

53. Olav Christensen 1952, s. 24.

54. Haderslev Handelsforenings forhandlingsprotokol 8. feb. 1912.

55. Amtsblatt 1911, s. 422.

56. Haderslev rådstuearkiv IX, Acta 9, 1 b.

57. Dannevirke 24. juni 1914.

58. Hedrich s. 188.

59. Betænkning 1923, s. 17.

60. Paap s. 101.

61. Tschirschnitz s. 3.

62. Ibid. s. $22 f$.

63. Paap s. 97.

64. Dreessen s. 5.

65. Ibid. s. 11 .

66. Paap s. 103

67. Ibid. s. 102 .

68. Haderslev landrådsarkiv fag 164, 2 .

69. Jahresbericht 1883.

70. Som note 56 .

71. Dannevirke 23. maj 1892.

72. Ibid. 10. maj 1893.

73. Schmidt: Strassen und Wege.

74. Tschirschnitz, s. 1 f. 
75. Senderborg byarkiv 245.

76. Larsen s. $45 \mathrm{f}$.

77. Dybbøl-Posten 25. jan. 1895.

78. Tschirschnitz s. 3.

79. Ibid. s. 6.

80. Ibid. s. 18.

81. Bericht 1903.

82. Sønderborg amtsbaners arkiv 213.

83. Flensburg. Geschichte einer Grenzstadt s. 365.

84. Eskildsen s. 58.

85. Kamphövener s. 72.

86. Haderslev Handelsforenings forhandlingsprotokol.

87. Dannevirke 6. marts 1893.

88. Wilcke I, s. $19 \mathrm{ff}$.

89. Ibid. s. $34-45$.

90. Ibid. s. 46.

91. Hejmdal 19. jan. 1899.

92. Haderslev Handelsforenings forhandlingsprotokol, december 1899.

93. Olav Christensen 1969, s. 32.

94. Kamphövener, s. 39 og 71.

95. Olav Christensen 1952, s. 18.

96. Wilcke II, s. $11 \mathrm{ff}$.

97. Ibid. s. 30ff.

98. Geschäfts-Bericht $\mathrm{Had}$ 1910/11.

99. Dannevirke 18. aug. 1910.

100. H. P. Hanssen s. 316.

101. Kamphövener s. $70 \mathrm{ff}$.

102. Kirkeby og Schack s. 286.

103. Paap s. 103.

104. Sønderjyllands Historie V, s. 466.

105. Mackeprang: Nordslesvig s. 247.

106. Betænkning 1923, s. 139.

107. Mangler.

108. H. P. Hanssen s. 316.

109. Hansen: Den nordslesvigske Landboforening s. 273.

110. Sønderjyllands Historie V, s. 451.

111. Hedrich, s. 167.

112. Geschäfts-Bericht Had og Abenrå.

113. Kamphövener s. 40 .

114. Paap s. 105.

115. Bericht $1901 / 02$.

116. Kamphövener s. 38.

117. Alnor s. 283.

118. Haderslev Handelsforenings forhandlingsprotokol 15. feb. 1896.

119. Geschäfts-Bericht Had 1910/11.

120. Aagesen s. 119.

121. Laurids Skaus brevveksling s. 608.

122. Brødrene Gram s. 8.

123. Flensborg Bys Hist II, s. 237f. - Jahresbericht 1883, 1885 og 1889.

124. Sønderborg Bys Hist II, s. 40. 
125. Bericht 1903.

126. Trap 5. udg. s. 415.

127. Sønderborg Bys Hist II, s. 67.

128. Ibid. s. 68 .

129. Trap 5. udg., s. 131.

130. Geschäfts-Bericht Had.

131. Troels Fink 1943.

132. Ábenrå Bys Hist III, s. 100.

133. Dahl og Linvald s. $151 \mathrm{f}$.

134. Verkehrsstatistik.

135. Clausen s. 31.

136. Sønderjyllands Historie V, s. 451.

137. Jacobsen s. 259.

138. Ibid. s. $278 \mathrm{f}$.

139. Verkehrsstatistik og D.S.B. Beretning.

140. Mackeprang: Tønder s. 263.

141. Flensburg. Geschichte einer Grenzstadt s. 483.

142. Klee og Poulsen, s. 14.

143. Hejselbjerg Paulsen s. 34 og 38.

Rettelse: Jernbanestrækningen Bredebro-Løgumkloster var ikke en småbane, således som det er anført på kortet fig. 4, s. 44, men en statsbane. 